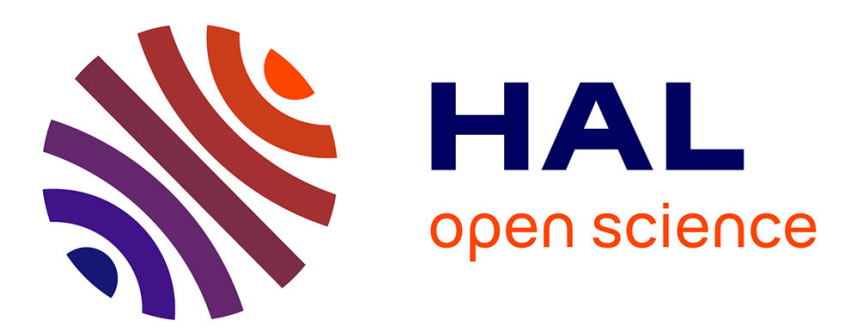

\title{
Current and novel approaches to downstream processing of microalgae: A review
}

Christos Nitsos, Rayen Filali, Behnam Taidi, Julien Lemaire

\section{To cite this version:}

Christos Nitsos, Rayen Filali, Behnam Taidi, Julien Lemaire. Current and novel approaches to downstream processing of microalgae: A review. Biotechnology Advances, 2020, 45, pp.107650. 10.1016/j.biotechadv.2020.107650 . hal-03051736

\section{HAL Id: hal-03051736 https://hal.science/hal-03051736}

Submitted on 10 Dec 2020

HAL is a multi-disciplinary open access archive for the deposit and dissemination of scientific research documents, whether they are published or not. The documents may come from teaching and research institutions in France or abroad, or from public or private research centers.
L'archive ouverte pluridisciplinaire $\mathbf{H A L}$, est destinée au dépôt et à la diffusion de documents scientifiques de niveau recherche, publiés ou non, émanant des établissements d'enseignement et de recherche français ou étrangers, des laboratoires publics ou privés. 
1 Current and novel approaches to downstream processing of microalgae: A

2 review

3 Christos Nitsos ${ }^{\mathrm{a}}$, Rayen Filali ${ }^{\mathrm{a}}$, Behnam Taidi ${ }^{\mathrm{b}}$, Julien Lemaire ${ }^{\mathrm{a}}$

$4 \quad{ }^{a}$ LGPM, CentraleSupélec, Université paris-Saclay, SFR Condorcet FR CNRS 3417, Centre

5 Européen de Biotechnologie et de Bioéconomie (CEBB), 3 rue des Rouges Terres 51110,

6 Pomacle, France

$7 \quad{ }^{b}$ LGPM, CentraleSupélec, Unierstiy of Paris Sacaly, Bât Gustave Eiffel, 3 rue Joliot Curie

891190 Gif-sur-Yvette FRANCE

9 Christos Nitsos: christos.nitsos@centralesupelec.fr

10 Rayen Filali: rayen.filali@ centralesupelec.fr

11 *Corresponding author Behnam Taidi: behnam.taidi@centralesupelec.fr

12 Julien Lemaire: julien.lemaire@ centralesupelec.fr 

review

Abstract

Biotechnological application of microalgae cultures at large scale has significant potential in the various fields of biofuels, food and feed, cosmetic, pharmaceutic, environmental remediation and water treatment. Despite this great potential application, industrialisation of microalgae culture and valorisation is still faced with serious remaining challenges in culture scale-up, harvesting and extraction of target molecules. This review presents a general summary of current techniques for harvesting and extraction of biomolecules from microalgae, their relative merits and potential for industrial application. The cell wall composition and its impact on microalgae cell disruption is discussed. Additionally, more recent progress and promising experimental methods and studies are summarised that would allow the reader to further investigate the state of the art. A final survey of energetic assessments of the different techniques is also made. Bead milling and high-pressure homogenisation seem to give clear advantages in terms of target high value compounds extraction from microalgae, with enzyme hydrolysis as a promising emerging technique. Future industrialisation of microalgae for high scale biotechnological processing will require the establishment of universal comparisonstandards that would enable easy assessment of one technique against another.

Keywords: Biotechnology, microalgae, harvesting, downstream processing, cell wall disruption, high value molecule extraction, bioenergy 
53 1. Introduction 3

$54 \quad 1.1$ Microalgae in the context of biorefinery 5

55 1.2 Microalgal cell wall recalcitrance $\quad 6$

56 2. Harvesting 8

57 2.1 Sedimentation $\quad 8$

58 2.2 Coagulation-Flocculation $\quad 9$

$59 \quad 2.3$ Centrifugation $\quad 11$

$60 \quad 2.4$ Flotation 11

$61 \quad 2.5$ Membrane filtration $\quad 12$

62 3. Pretreatment of microalgae \& Extraction of target molecules 13

$63 \quad 3.1$ Physical methods 13

$64 \quad 3.1 .1$ Milling 13

$65 \quad 3.1 .2$ High-pressure homogenization (HPH) 15

$66 \quad 3.1 .3$ Ultrasonication $\quad 17$

$67 \quad 3.1 .4$ Pulsed Electric Field 17

$68 \quad 3.1 .5$ Drying 19

$69 \quad 3.2$ Chemical methods $\quad 19$

$\begin{array}{lll}70 & 3.2 .1 \text { Hydrothermal } & 19\end{array}$

$71 \quad 3.2 .2$ Acid treatment 22

$72 \quad 3.2 .3$ Alkaline treatment 23

$73 \quad 3.2 .4$ Oxidative pretreatment 24

74 3.2.4.1 Ozonolysis 24

$75 \quad 3.2 .4 .2$ Hydrogen peroxide 25

$\begin{array}{lll}76 & 3.3 \text { Enzymatic methods } & 26\end{array}$

$\begin{array}{lll}77 & 3.4 \text { Novel downstream processing concepts } & 27\end{array}$

$\begin{array}{ll}78 & 3.5 \text { Energy efficiency of downstream processing } 31\end{array}$

79 4. Conclusion and outlook 33

80 References $\quad 35$

81

1. Introduction

83 Since $\mathrm{CO}_{2}$ has been identified as a potent greenhouse gas, reduction of anthropogenic $\mathrm{CO}_{2}$ emissions 84 has become a focal point of both policy and research initiatives. The extended use of fossil hydrocarbon 85 reserves to produce heat, electricity, transportation fuel and precursors for the chemical industry, have 86 unbalanced the natural carbon cycle leading to increased $\mathrm{CO}_{2}$ levels in the atmosphere. This has been 
linked to the increase in the average global temperature. Several world agreements have promoted the replacement of traditional fossil derived energy with renewable solar, wind, water, geothermal and biomass alternatives (Chu et al., 2017; Demirbas et al., 2009). More specifically, the Paris Agreement has set the ambitious goal to reduce $\mathrm{CO}_{2}$ emissions to a level that will limit average global temperature rise to less than $2{ }^{\circ} \mathrm{C}$ (Krug, 2018). In this context, not only reducing anthropogenic $\mathrm{CO}_{2}$ generation, but also $\mathrm{CO}_{2}$ capturing technologies have become important.

Microalgae ability to fix $\mathrm{CO}_{2}$ and convert it into useful molecules via photosynthesis makes them attractive for the emerging bio economy. Microalgae can be divided into prokaryotic blue and green algae (cyanobacteria), and eukaryotic microalgae that are further divided into Chlorophyta, Phaecophyta, and Chrysophyceae based on the type of their photosynthetic pigments (green, brown and gold, respectively) (Masojídek et al., 2013). The production of biomass and useful metabolic products from a readily available and free carbon source is not the only advantage of microalgae. Their ability to utilize inorganic nutrients such as nitrogen and phosphorus, allows their use for tertiary and quaternary effluents treatment from secondary wastewater treatment process plants (Abdel-Raouf et al., 2012). Organic carbon assimilation from microalgae in heterotrophic or photomixotrophic growth metabolism is also possible, enhancing their wastewater treatment potential (Neilson and Lewin, 1974) and potential valorization on the anaerobic co-digestion process. Coupling wastewater treatment with $\mathrm{CO}_{2}$ capture and biomass production may serve as an elegant and efficient solution of current environmental and economic challenges, for example by integrating $\mathrm{CO}_{2}$ from industrial flue gasses to microalgal wastewater treatment (Molazadeh et al., 2019; Razzak et al., 2013). Although this type of an integrated approach has not yet reached maturity, the All-gas project is an example of municipal wastewater treatment, $\mathrm{CO}_{2}$ fixation and biogas production that has reached the demonstration scale (Maga, 2017).

As with higher plants, microalgae require land for their production, although the use of coastal waters are increasingly suggested. Microalgae, however, can give higher productivity compared to terrestrial crops due to their continuous cultivation mode, fast growth rate, short cycle doubling time, year-round operation and higher content in target molecules (Eing et al., 2013). By extrapolating results from laboratory scale microalgae cultivation to the commercial scale it was estimated that several Chlorophyta achieved much higher oil yields compared to land crops (Nascimento et al., 2014). For example, Chlamydomonas sp. and Chlorella vulgaris oil yield was $10.4 \mathrm{~m}^{3} \mathrm{ha}^{-1} \mathrm{year}^{-1}$ and $44.4 \mathrm{~m}^{3} \mathrm{ha}^{-1}$ year ${ }^{-1}$, respectively. Palm oil productivity on the other hand was estimated at only $6 \mathrm{~m}^{3} \mathrm{ha}^{-1}$ year ${ }^{-1}$ (Nascimento et al., 2014). Biomass yields of microalgae is also higher and in the range of 70-100 $\mathrm{t} \mathrm{DW}$

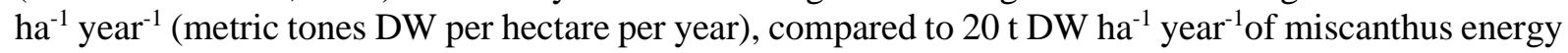
culture (Eing et al., 2013; Lewandowski and Heinz, 2003), where DW is the dry weight of the sample. Both open and closed systems have been used for microalgae culture. Open systems mainly consist of raceway ponds with paddle wheels (Filali et al., 2019) and open cascade systems (Lee, 2001) and are characterized by design and construction simplicity, lower capital cost, natural light and temperature control and easier maintenance. Their disadvantages include microbial contamination, high area demand, dependence on environmental conditions, insufficient mixing and mass transfer (Ugwu, C.U. and Aoyagi, H., 2012; Acién et al., 2017; Eing et al., 2013). Closed culture systems (photobioreactors) on the other hand require less space, enable better operational parameters control, allow axenic culture conditions, and good culture mixing, but at higher construction and operation cost. This makes them suitable for the cultivation of more microalgae species, including less robust species, or when the targeted product purity is essential (Acién et al., 2017). Harvesting and concentration costs of microalgal biomass is a major inconvenience of the overall biorefinery process in both reactor types.

Microalgae cultivation requires significant area and land availability can be an important limiting factor of a microalgae-based bioeconomy. The low DW biomass productivity of photosynthetic microalgae cultures means that large volume of water is required to produce relatively low biomass amounts. Available alkaline or saline water reservoirs valorisation can partially cover the water requirements of microalgae cultivation (Hannon et al., 2010); such a solution, however, would be limited to a small number of microalgae species adapted to survive in harsh media. Industrial process water, with or without supplements, can also serve as a growth medium for microalgae cultures. 
Light is the main limiting factor in microalgae cultures (Carvalho et al., 2011). Photosynthetic biomass growth and productivity relies on $\mathrm{CO}_{2}$ assimilation, and the flux of light energy the cells are exposed to (Clement-Larosiere et al., 2014). Additionally, exposure to light is not homogeneous inside photobioreactors, and depends on the geometrical configuration and the culture systems hydrodynamic properties. The cells auto-shading and formation of biofilms on the photobioreactor walls or on the culture's surface also have a strong impact on light penetration. The drop in light intensity is very steep even a few millimetres from the photobioreactor surface. Indeed, photobioreactors are naturally divided into light and dark zones, with efficient photosynthetic activity occurring only in the light zones. Depending on the bioreactor design parameters, such as tube diameter or pond depth, the dark areas can constitute the majority of the reactor volume (Carvalho et al., 2011). Light limitation is a major reason for the low productivity of photoautotrophic cultures compared to heterotrophic fermentations. Temperature effects can also significantly affect production efficiency and may require temperature control increasing investment and operation costs (Ras et al., 2013). Typical biomass concentration for photoautotrophic cultures is in the region of 0.5 to $2.0 \mathrm{~g} \mathrm{~L}^{-1}$, whereas in heterotrophic cultures biomass concentrations of $18 \mathrm{~g} \mathrm{~L}^{-1}$ (Cheng et al., 2009) and $24 \mathrm{~g} \mathrm{~L}^{-1}$ (Chen and Walker, 2011) are possible. For traditional industrial fermentations utilizing yeast, concentrations of greater than 50 or $60 \mathrm{~g} \mathrm{~L}^{-1}$ can be achieved (Di Serio et al., 2001; Paredes-López et al., 1976). In turn, the low cell densities of microalgae cultures make downstream processing, such as cell concentration and extraction of valuable molecules, critical to the success of industrial microalgae valorization (Gayen et al., 2019).

\subsection{Microalgae in the context of biorefinery}

Deriving value from microalgae through a biorefinery operation (Fig.1) can appear rather attractive as the carbon nutrient $\left(\mathrm{CO}_{2}\right)$ is not only free but its removal from the atmosphere is desired. The use of microalgae, however, presents several challenges: the growth of microalgae requires significant quantities of carbon, nitrogen and phosphorus. The inorganic carbon required for photosynthesis can come either from $\mathrm{CO}_{2}$ or from dissolved bicarbonate ions in the medium (Gonçalves et al., 2017). Inorganic nitrogen (nitrate, nitrite, ammonium, ammonia, molecular nitrogen) uptake is species dependent (Hellebust and Ahmad, 1989). Organic compounds such as urea can also be used as a nitrogen source (Kim et al., 2016). Phosphorus, on the other hand, is assimilated mainly as phosphate ions, with the ability of organic phosphorus uptake also shown (Singh et al., 2018). Most microalgae have the ability to uptake more phosphorus than is required for growth and store it in the form of inorganic polyphosphate. This natural adaptation to phosphorus poor environments is termed luxury phosphorus uptake (Solovchenko et al., 2019). The use of industrial fertilizers as sources of nitrogen and phosphorus can be a cheaper alternative to growth medium formulation increasing the economic sustainability of microalgae culture and valorisation. Magnesium $\left(\mathrm{Mg}^{2+}\right)$, an important component of the photosynthetic apparatus, is also critical for microalgae growth and biomass productivity is related to its concentration in the growth medium (Ben Amor-Ben Ayed et al., 2016, 2015). Coupling microalgae biorefinery with process water treatment and carbon dioxide biofixation is economically attractive for sustainable microalgae culture. Process water is rich in inorganic content that is expensive to remove in traditional tertiary process water treatment operations. Their use as growth media in a biorefinery would reduce the cost of both process water treatment and microalgae culture. In addition, the process water would provide a readily available source of water, and organic and/or inorganic compound necessary for microalgae growth. The ability of microalgae to remove nitrogen (Delgadillo-Mirquez et al., 2016) magnesium (Ben Ayed et al., 2017) and excess phosphorus -through luxury phosphorus uptake(Solovchenko et al., 2019) from their growth medium, makes them suitable for such water depollution applications (Fig. 1). The biomass produced can be used as a fertilizer or converted to renewable fuels and energy and increase the operation's sustainability. This could be an interesting solution despite the problem of light penetration into the culture caused by the secondary effluent's turbidity and colour. Lack or limitations of nutrients that are necessary for growth in the medium can affect the composition of the microalgae biomass. Such limitations are often desirable and are induced as a stress factor; can be accomplished by formulation of the growth medium. For example, nitrogen limitation in the latter stages of microalgae growth can induce lipid production as an energy storage mechanism, and therefore 
increase the value of the produced biomass (Juneja et al., 2013). The effects of limitation of major nutrients in the growth medium can be seen in Table 1.

Figure 1

Table 1

The low dry weight content of microalgae cultures (typically around $1 \mathrm{~g} \mathrm{~L}^{-1}$ ) makes harvesting and concentration an expensive unit operation of any biorefinery. Harvesting and dewatering are the main downstream processes required for any applications where the whole microalgae biomass can be used directly as the final product, such as for animal and fish feed or food supplements (e.g. Arthrospira platensis tablets and powder). Biomass concentration can be achieved by the combination of some techniques such as settling, decantation, centrifugation and filtration; all followed by an operatory process of microalgae conditioning by drying of the concentrated pastes (Raja et al., 2018). Harvesting and dewatering processes may also include membrane filtration, shaking separators, flotation and flocculation, or pressing.

The various molecules of interest in the microalgae biomass can be classified into structural e.g. cell wall carbohydrates and proteins and cell membrane lipids; and non-structural e.g. storage lipids and carbohydrates, vitamins, polyunsaturated fatty acids and pigments (Cuellar-Bermudez et al., 2015; Shannon and Abu-Ghannam, 2018). These may be the final target molecules, as in the case of $\omega-3$ or $\omega-$ 6 fatty acids and $\beta$-carotene that can be used in food supplements; or used as feedstock for fuels and chemical products, as in the case of carbohydrates and lipids. Such diversity in the chemical composition of microalgae, requires a fractionation step of the target molecule. The fractionation process must be selective in order to maximize the desired molecule's yield and minimize formation of unwanted and inhibitory products.

Cell disruption can be achieved by physical (Ultrasonication, High Pressure Homogenization, Bead Milling, Pulsed Electric Field) chemical (Acid, Alkaline and Oxidation), thermal (Hydrothermal, Steam Explosion) and biological methods (Enzymatic treatment) (Soo Youn Lee et al., 2017). During cell wall disruption, intracellular molecules can be extracted with organic solvents (Araujo et al., 2013), ionic liquids (Y. Zhang et al., 2018), supercritical $\mathrm{CO}_{2}$ (Reyes et al., 2016; Cheng et al., 2011) or supercritical mixtures of $\mathrm{CO}_{2}$ and solvents (Obeid et al., 2018). Cell-wall components fractionation, may require their further depolymerization via hydrothermal (Lorente et al., 2017), acid (Hernández et al., 2015) or enzymatic hydrolysis (Sierra et al., 2017). The targeted molecules separation and purification can be performed with chromatography (Bousquet et al., 1994; Fábryová et al., 2019) and membrane technology (Giorno et al., 2013).

\section{2 Microalgal cell wall recalcitrance}

The bulk production of fuels such as biogas (Córdova et al., 2018) or bio-oil through hydrothermal liquefaction (Hu et al., 2017) are common methods of deriving value from microalgae biomass. In such cases, cell disruption does not facilitate extraction or fractionation of molecules but enhances the conversion reactions towards the desired end products (Mahdy et al., 2014a; B. Zhang et al., 2018). Cell wall disruption may be essential for the efficient extraction of intracellular molecules such as pigments and oils. Cell wall components may themselves be target molecules, requiring disruption for their efficient fractionation e.g. carbohydrates for bioethanol production (Kim et al., 2012), or hydrocarbons from the Botryococcus extracellular matrix (Ciudad et al., 2014)

Cell wall structure (Fig. 2) and composition has been extensively reviewed elsewhere (Baudelet et al., 2017). Cell wall thickness and chemical composition have been identified as the most important factors determining the cell wall strength (Zhipeng Duan et al., 2017). Cell wall robustness can vary related to microalgae species (Montsant et al., 2001). Isochrysis Galbana completely lacks a cell wall (Throndsen, 1997), making it very fragile, whereas Chlorella $s p$. have a glucosamine rigid cell wall and a hemicellulose-like cell wall layer mainly of galactose and mannose sugars (Rodrigues and da Silva Bon, 
2011). Haematococcus pluvialis has a very thick cell wall composed of cellulose-like polysaccharides and a very resistant polymer, algaenan (Hagen et al., 2002). Algaenan is one of the most inert microalgae cell wall components and very resistant to physical, chemical and enzymatic pretreatment (MendesPinto et al., 2001).

The cell wall of the blue-green alga A. platensis is composed of four layers one of which is a more robust peptidoglycan layer (Van Eykelenburg, 1977). Tisochrysis lutea has a cell wall consisting of two-layered plates (Orlova et al., 2019). A comparative study of cell disruption of various species with ultrasonication has correlated cell wall composition and structure to resistance to physical damage (shear stress) (Zhipeng Duan et al., 2017). From the treatment of green algae and cyanobacteria the following suggested order of cell wall robustness can be proposed for a few species: Chlorella pyrenoidosa > Synechococcus elongatus $>$ Microcystis aeruginosa $>$ Chlamydomonas reinhardtii. The more resistant cell wall of $C$. pyrenoidosa is composed mainly of cellulose rich polysaccharides, the cyanobacteria of a peptidoglycan layer with an extracellular mucilage layer and a further, serrated external layer (S-layer) and finally, of the rupture prone C. reinhardtii of hydroxyproline-rich glycoproteins (Zhipeng Duan et al., 2017). The cell wall of Chlorella strains also contains a chitin-like layer (Kapaun and Reisser, 1995). Besides the organic layers some microalgae cell walls have inorganic components, like the cell wall of the diatom Phaeodactylum tricornutum, that contains a silica shell (Gügi et al., 2015).

Similar indirect suggestions for a possible correlation between cell wall composition and robustness exist in other articles. In a study of rupture of Tetraselmis suecica., Chlorella sp. and Nannochloropsis sp, by High Pressure Homogenization the pressure required to rupture $50 \%$ of the cells was determined at 170 bar, 1060 bar and 1380 bar, respectively (Spiden et al., 2013). The order of cell wall robustness of these species therefore can be proposed as: Nannochloropsis sp. > Chlorella sp. $>$ T. suecica. Although the cell wall composition of these species was not measured in the study, it is noted from the literature that they are made up from polymers resistant to mechanical rupture, polysaccharides and glycoproteins, and carbohydrate scales, for Tetraselmis suecica., Chlorella sp. and Nannochloropsis sp, respectively (Spiden et al., 2013). In a similar approach, cell fragility at 1750 bar was studied (Taleb A. 2016) from which the order of cell wall robustness can be proposed for the following species: Scenedesmus sp. UTEX 1589 > Nannochloropsis salina 537 CCMP > Scenedesmus obliquus 393 UTEX > Nannochloropsis gaditana 527 CCMP > Parachlorella kessleri 2229 UTEX. Again, the cell wall composition of the species was not provided.

A second level of recalcitrance is presented by microalgae organized in coenobial communities, held together by extracellular structures. For example, Botryococcus strains have thick cell walls, rich in hemicellulose-like carbohydrates predominantly of arabinose and galactose composition, an algaenan layer, and form colonies held together with a hydrocarbon extracellular matrix. Equally complex is the cell wall of Scenedesmus, containing cellulose-like carbohydrate layers, algaenan and an external coenobial seath when the cells are grown in colonies.

Figure 2

Modifications during the different stages of microalgae growth can also significantly affect the recalcitrance of the cell wall. For example, $H$. pluvialis vegetative cells are susceptible to breakage at moderate pressures (4000 to $10,000 \mathrm{psi}$ ), whereas cysts with thicker algaenan-rich cell walls required very high pressure (20,000 psi) for complete cell disruption (Montsant et al., 2001). It has also been shown that growth rate can also affect cell wall robustness, as cultures grown at higher rates produce cells with thinner walls (Němcová and Kalina, 2000). In general, the thickness and chemical composition of the cell wall can vary a lot even in the same species depending on the growth conditions (Liu et al., 2006). Concerning the enzymatic methods, the multilayered structure of a cell wall poses an additional challenge as each layer may require enzymatic treatment by a different class of enzymes, increasing the enzymatic cocktail's complexity and cost, or requiring multi-stage pretreatment. In electricity-based pretreatment methods, such as Pulsed Electric Field, the small size of the microalgae cell alse enhances resistance to disruption.

287 Structural modifications induced from the specie's growth state, energy requirements, pretreatment costs 288 and price of the desired products must be carefully considered in order to select an appropriate cell 
disruption method. Sensitivity of the targeted molecules to degradation during pretreatment must also be considered in order to minimize losses in the final product yield and biological activity. Some interesting microalgae species, their cell wall composition, targeted molecules, and their respective prices, are summarized in Table 2.

Table 2

\section{Harvesting}

Harvesting is the solid-liquid separation of cells from the growth medium. The microalgae cells are the main culture product, whereas the nutrient depleted medium is a valuable water source that can be recycled into the bioreactor directly or supplemented with nutrients, if required. The very low microalgae biomass concentrations make harvesting a critical operation unit for a biorefinery from the economical point of view. Further downstream processing steps such as cell disruption and extractionfractionation cannot be performed at low solids content as the high diluted solutions would not be treated. The typically low biomass yield in microalgae production systems poses severe economic and energetic restrictions to the harvesting and consequently to the whole biorefinery process. Operating cost cannot exceed the value of final products, and since at least some of the biorefinery end products will be fuels, the harvesting energy should not exceed the biomass energy content. The relatively small size of microalgae cells -typically between 2 and $25 \mu \mathrm{m}$ as well as the negative surface charge pose additional challenges to the harvesting step. Harvesting can be divided into preconcentration, aiming to increase the initial biomass content from $0.5-1.0 \%$ to around 3\% and dewatering that can lead to a very concentrated microalgal biomass, up to $25 \%$ in dry weight (Muylaert et al., 2017). In the case of larger size filamentous microalgae like A. platensis the biomass can be efficiently harvested using vibrating sieves, a relatively simple technology (Shelef et al., 1984).

\subsection{Sedimentation}

Natural sedimentation of microalgae cells is a very simple and low-cost harvesting method. The speed of sedimentation depends on cell diameter and the density difference between the cell and the growth medium, according to Stoke's equation, commonly used as a first approximation:

$$
V_{s}=\frac{g d^{2}\left(\rho_{c}-\rho_{m}\right)}{18 \mu}
$$

where, $V_{s}$ is sedimentation velocity, $g$ accelertion of gravity, $d$ cell diameter, $\rho_{\mathrm{c}}$ microalgae cells density, $\rho_{\mathrm{m}}$ medium density, and $\mu$ the medium viscosity. The Stoke's equation can describe sedimentation of round shaped cells with good approximation, however its use in not universal and for different cell shapes the equation cannot be applied (Peperzak et al. 2003). Indeed, when the shape of the microalgae is not spherical or where there are formations like thorns on the surface of the cell the correlation of cell size to settling rate can be negative (Peperzak et al. 2003). A negative correlation between size and sedimentation rate has also been observed in the case of some microalgae colonies (Peperzak et al. 2003). It seems that cell density -or the difference between cell and medium density- is more significant and higher cell densities will result in higher sedimentation rates (Peperzak et al. 2003). Sedimentation velocity can vary several orders of magnitude among microalgae species depending on cell size, density and shape. As a general rule small diameter and low-density microalgae tend to sediment very slowly compared to larger and denser cells (Mathimani and Mallick, 2018).

In mixed microalgae cultures, sedimentation by gravity is an efficient harvesting method if the colony is dominated by species with large settling velocities. When slow settling microalgae become dominant the harvesting efficiency is reduced even at prolonged settling periods of 24h (Park et al., 2011). Natural sedimentation has been proposed as a harvesting method or pre-concentration step even for slow settling microalgae like Monoraphidium sp. that could be harvested after $24 \mathrm{~h}$ with a $98 \%$ yield (Yu et al., 2012). 
The filamentous cyanobacterium A. platensis with a fast sedimentation velocity of $0.64 \mathrm{~m} \mathrm{~h}^{-1}$ and accumulation of carbohydrates during nitrogen starvation could be concentrated 15 times by spontaneous sedimentation that achieved 93\% removal of water (Depraetere et al., 2015). The diatom Amphora with the impressive sedimentation velocity of $2.91 \mathrm{~m} \mathrm{~h}^{-1}$, can be harvested by a simple low cost and fast gravity sedimentation (Chtourou et al., 2015). It also exhibits relatively fast growth rate and significant fat accumulation. Microalgae with such properties have a great advantage compared to slowly settling ones in terms of harvesting efficiency. Their valorization could be prioritized over other species as they may be an economically viable solution to a truly efficient microalgae biorefinery.

Nitrogen starvation in Nannochloropsis salina and Chlorella sp. cultures led to reduction in the cell density and settling velocity by as much as an order of magnitude at the latter culture stages (Baroni et al., 2019). This could be a disadvantage for harvesting as nitrogen starvation is typically related to lipid accumulation, and the lipid rich cells could be harder to separate. A compromise might be necessary between biomass, lipid yields and settling velocity if unassisted gravity sedimentation is being considered as the sole method of harvesting. However, as gravity sedimentation can seldom induce the required biomass dewatering, its use for pre-concentration followed by another method is preferable. For example, gravity sedimentation coupled with centrifugation can reduce the harvesting cost and energy by a factor of 30 compared to centrifugation alone (Badvipour et al., 2016).

\subsection{Coagulation-Flocculation}

Coagulation and flocculation are conventional technologies used in water treatment to promote the separation of small particles by sedimentation. Both methods involve the addition of compounds which cause the agglomeration of particles into larger flocs to increase their sedimentation velocity, according to Stoke's equation. Coagulation is a chemical technique based on the neutralization of charge of the microalgae surface to disrupt the repulsive forces and promote cell aggregation. Flocculation is a physical method that uses compounds on which cells can clump together without involving surface charge neutralization. There is a subtle difference between the two phenomena but in the scientific literature most authors only refer to flocculation.

Coagulation can occur with the addition of inexpensive multivalent salts such as $\mathrm{Al}_{2}\left(\mathrm{SO}_{4}\right)_{3}$ that could remove more than $85 \%$ of $N$. salina in $62 \mathrm{~min}$, although at a relatively high dosage $-229 \mathrm{mg} \mathrm{L}^{-1}$ (Chatsungnoen and Chisti, 2016). Coagulation of $C$. reinhardtii at elevated $\mathrm{pH}$ values was induced by ferric $\left(\mathrm{FeCl}_{3}\right)$, calcium $\left(\mathrm{CaCl}_{2}\right)$, and magnesium chlorides $\left(\mathrm{MgCl}_{2}\right)$. Even at very low concentrations $(>5$ $\mathrm{mM}$ ) more than $90 \%$ biomass harvesting could be achieved making this an attractive and inexpensive method (Fan et al., 2017).

Coagulation with multivalent cations can be improved by $\mathrm{pH}$ adjustment to basic values. Indeed, its efficiency can be related to the cells zeta potential, a pH depended phenomenon (Fan et al., 2017). Adjustment of $\mathrm{pH}$ to 9.51 induced coagulation of Chaetoceros calcitrans and $89 \%$ of cells were harvested with a sedimentation rate of $0.125 \mathrm{~m} \mathrm{~h}^{-1}$ and a concentration factor of 4 in $10 \mathrm{~min}$ (Şirin et al., 2015). Adjustment of $\mathrm{pH}$ to 10.2 with addition of sodium or potassium hydroxide led to high harvesting efficiency (> 90\%) of C. calcitrans biomass. At increased polyelectrolyte dosages the sedimentation rate was greatly improved without loss of cell viability or harvesting yield (Harith et al., 2009). $C$. vulgaris biomass required a $\mathrm{pH}$ higher than 11 for coagulation efficiency above $90 \%$ with magnesium hydroxide for reuse (Vandamme et al., 2012). Microalgae biomass contamination by the coagulation reagents is the biggest process disadvantage as they can reduce the extracted biomolecules quality or interfere with other downstream processing operations (Vandamme et al., 2012). This can be overcome by re-suspending the coagulation reagent after harvesting. For example in the coagulation of $C$. vulgaris and Phaeodactylum tricornutum with $\mathrm{Mg}(\mathrm{OH})_{2}$, a mild acidification of the microalgae slurry could dissolve $95 \%$ of the precipitated magnesium hydroxide (Vandamme et al., 2015).

The use of inorganic reagents can be less effective when used for the harvesting of marine microalgae due to the shielding of cells by ions in the medium that lead to inhibition of floc formation (Vandamme et al., 2013). Organic polymers on the other hand can be effective flocculants for both marine and 
freshwater microalgae (Table 3). Organic polymers with positive charges also neutralize the negative surface charge of microalgae cells but can act on several cells simultaneously leading to a bridging effect (Figure 3) and floc formation. Reduced harvesting efficiencies have sometimes been observed at increased dosages of cationic polymers (Lam, 2017). This has been explained by a protection of the cells by the excess flocculant leading to surface charge reversal and repulsive forces from the cationic polymers inhibiting floc formation (Figure 3 ).

Figure 3

392

393

To achieve flocculation, charged organic polymers can be used such as, chitosan a natural-based cationic biopolymer, which is efficient at low concentrations. At $20 \mathrm{mg} \mathrm{L}^{-1}$ and $\mathrm{pH} 8$ a $90 \%$ harvesting efficiency and $80 \%$ cell viability of $C$. calcitrans is possible (Harith et al., 2009). Although alginate has been shown to not induce flocculation in some cases (Zhu et al., 2014), its addition with chitosan that has an opposite charge, creates a polyelectrolyte complex that can enable harvesting of microalgae by flocculation at ppm range concentrations. Scenedesmus obliquus biomass was harvested with an efficiency of $86 \%$, with this way (Matter et al., 2018). Cationic starch is another cationic biopolymer that can induce flocculation of Chlorella protothecoides at $40 \mathrm{mg} \mathrm{L}^{-1}$ and achieves an extraction efficiency of $98 \%$ at near neutral and alkaline pH values (Letelier-Gordo et al., 2014). Polyacrylamide is another type of organic polymer that has been extensively used for harvesting of microalgae by flocculation. They achieved very high flocculation efficiencies between $90 \%$ and $100 \%$ for a variety of microalgae species. (Van Haver and Nayar, 2017). The charge of the polymers seems to play a more important role in the case of marine microalgae. For example, in the marine microalgae $N$. salina using polyacrylamide polymers of medium, high, and very high charge -with all other parameters kept the same- improved the harvesting efficiency from $73 \%$ to $88 \%$ to $94 \%$, respectively (Table 3 ). This effect was not observed for the freshwater microalgae $C$. vulgaris, where the harvesting efficiency remained almost $100 \%$ irrespectively of the charge of the polymer (Van Haver and Nayar, 2017). This could be caused by the presence of salt ions in the marine microalgae medium that can partially neutralize or counteract the charge of the polymer; or it could be related to the surface charge of the individual species. In both cases it is worth noting that the very promising harvesting results were achieved with very low polyacrylamide dosages; $3 \mathrm{mg} \mathrm{L}^{-1}$ for $N$. salina and $1.66 \mathrm{mg} \mathrm{L}^{-1}$ for C. vulgaris (Van Haver and Nayar, 2017). Despite these promising results, polyacrylamides are potentially hazardous chemicals and their presence can contaminate the harvested biomass, making it unsuitable for pharmaceutical, cosmetic and food applications, and limiting their use to biofuels production.

Tannins is a class of phenolic biomolecules -present in plant biomass- that are very efficient flocculants (Table 3). POLYSEPAR ${ }^{\circledR}$ CFL25, a tannin quaternary ammonia salt with low molecular weight and high charge showed $95 \%$ harvesting efficiency of Chlorella sp. cells at a dosage of $30 \mathrm{mg} \mathrm{L}^{-1}$ (Van Haver and Nayar, 2017). Tanfloc SL, another tannin polymer of low molecular weight and low to medium charge could harvest $100 \%$ of $C$. vulgaris cells at a dose of $5 \mathrm{mg} \mathrm{L}^{-1}$ (Van Haver and Nayar, 2017). A lower cost bio flocculant has been produced by fermentation of rice bran with Bacillus agaradhaerens C9. The bioflocculant is possibly a hemicellulose oligomers hydrolysate as xylanase activity was detected in the fermentation broth. It achieved around $90 \%$ harvesting efficiency at a $60 \mathrm{mg} \mathrm{L}^{-1}$ concentration (Liu et al., 2017). Other bioflocculant polymers such as poly $\gamma$-glutamic acid produced by Bacillus Licheniformis have been successfully used for the flocculation of Desmodesmus brasiliensis at $>98 \%$ efficiency. Anionic and non-ionic polymers showed no or poor flocculation efficiency in most cases, or had inferior performance compared to cationic ones (Tilton et al., 1972; Udom et al., 2013; Uduman et al., 2010). This could be caused by the fact that the surface charges of microalgae are usually negative (Danquah et al., 2009) and their neutralization requires positively charged flocculants or combination with coagulants. Another interesting approach is thermal flocculation without the addition of a flocculating agent. For example, thermal treatment of C. vulgaris and S. obliquus induced the secretion of organic matter that acts as a flocculating agent and causes the formation of flocs. The authors have hypothesized that the organic matter can be polysaccharides and/or protein (Xue et al., 2019)

As harvesting can represent up to $30 \%$ of the total microalgae processing cost, coagulant or flocculant price can have a negative impact on biorefinery economics (Wu et al., 2015). Prices can vary significantly between the less expensive coagulant salts such as $\mathrm{Al}_{2}\left(\mathrm{SO}_{4}\right)_{3}\left(0.2 \$ \mathrm{~kg}^{-1}\right)$ and the more 
expensive flocculant: chitosan (19.6 \$ kg-1) (Wu et al., 2015). It has been deduced that coagulationflocculation can be only marginally cheaper than centrifugation; auto flocculation, bioflocculation and electroflocculation methods were suggested as more economically viable alternatives (Vandamme et al., 2013). The use of polyelectrolytes as economical flocculants has also been proposed, as the doses required are up to two orders of magnitude less than salts or chitosan and their cost is comparable to the inexpensive salt coagulants. (Granados et al., 2012).

Table 3

\subsection{Centrifugation}

Centrifugation process simply increases the $\mathrm{g}$ force accelerating settlement as stated by Stokes equation. Strain morphology can play an important role in the centrifugation efficiency. For example, linear $A$. platensis filaments could be harvested at around $85 \%$ efficiency at $4000 \mathrm{x} \mathrm{g}$ for $10 \mathrm{~min}$, in a laboratoryscale fixed angle rotor centrifuge. In contrast helical A. platensis filaments showed poor harvesting yield (around 50\%) even at $9000 \mathrm{x}$ g (Cuellar-Bermudez et al., 2019). S. obliquus cells could be removed from the culture by centrifugation at $3000 \mathrm{x}$ g for $10 \mathrm{~min}$, in a 750W TD5A centrifuge, with a harvest efficiency of $99.3 \%$ (Wang et al., 2019). Various types of centrifuges can be used to harvest and concentrate microalgae, such as, spiral plate centrifuge (Collet et al., 2011), decanter centrifuge (Adesanya et al., 2014), disk stack centrifuge (Milledge and Heaven, 2011), and hydrocyclone (Amaro et al., 2017).

Although centrifugation is a very efficient dewatering method, it has some of the highest energy requirements (Guldhe et al., 2016). Especially when microalgae are used to produce biofuels, the overall energy consumption should ideally be lower than the biofuel energy content. When producing biogas from microalgae, it was shown that neither centrifugation nor flocculation or sedimentation as a standalone harvesting method can meet this criterion as the energy input was greater than the energy content of the produced biogas. On the other hand, a positive energy balance can be achieved when centrifugation is combined with pre-concentration by sedimentation or flocculation, (Milledge and Heaven, 2017). Flocculation is used to preconcentrate the microalgal biomass or to reduce the energy costs of harvesting by producing large size flocs that can be centrifuged more efficiently than single cells (Collotta et al., 2017; Fan et al., 2017). In the harvesting of Chlorella sorokiniana cells by centrifugation, with or without preflocculation, the benefits of preflocculation were clearly shown. Preflocculation of the cells was performed with a dosage of $10 \mathrm{mg}$ chitosan $\mathrm{g}^{-1}$ dry algae weight more than $99 \%$ clarification efficiency. The performance of centrifugation with and without flocculation was similar (Xu et al., 2013). However, preflocculation decreased the volume of the algae suspension between 20 and 50 times, with more than $95 \%$ of the water being removed in the latter case, leading to significant reduction in the energy for dewatering (Xu et al., 2013). Preconcentration by natural settling can be another option for energy reduction of centrifugation. It was estimated, for example that the energy consumption for concentration of $C$. vulgaris cells by spiral plate centrifugation could be as low as $0.042 \mathrm{kWh} \mathrm{kg}^{-1}$ of biomass if preconcentrated by natural settling (Collet et al., 2011).

Disc stack centrifuges, on the other hand have a much higher energy consumption (Milledge and Heaven, 2011) that can represent almost up to half of the total energy requirements of a biorefinery (Mata et al., 2014). Hydrocyclone centrifugation is a low-cost and low energy option for harvesting microalgae cells, however, as this method can achieve low cell concentrations (below $0.4 \%$ suspended solids) its usefulness is limited to preconcentration (Amaro et al., 2017). Decanter centrifuges can achieve high solid concentrations (approx. 20\% DW) in continuous mode with pulsed discharges of the concentrated biomass. Its use is suggested together with flocculation (Ramos Tercero et al., 2014).

\subsection{Flotation}


Flotation can also be considered a gravity based harvesting method, but the strategy is opposite to the processes discussed above. The aim of this technique is to transfer the microalgae from suspension to the medium surface where they can be easily harvested by skimming. This is achieved by the introducing gas bubbles that attach to the cells and lift them. The microalgae cell attached to the gas bubble has much lower density compared to the medium. According to Stoke's equation, this creates a negative settling velocity or a rising velocity.

Several variations of flotation harvesting exist. In dissolved air flotation (DAF), pressure reduction of air saturated water leads to bubble formation. When optimized it can lead to high biomass harvesting yields. A $91 \%$ harvesting efficiency was achieved with dissolved air flotation in the pilot scale with a floatation tank of 3.8 L (Niaghi et al., 2015). DAF is usually more expensive due to the cost of water pressurization. In dispersed air flotation, air bubbles are created by gas injection into the medium through a diffuser or sparger, often assisted by mechanical agitation for more efficient dispersion. Bubble sizes typically fall within the 60 to $655 \mu \mathrm{m}$ range with a concentration of $210^{5}$ bubbles $\mathrm{cm}^{-3}$. The process efficiency depends on the formed bubbles stability as well as the proper bubble size (optimally below $500 \mu \mathrm{m}$ ) (Alhattab and Brooks, 2017). Dispersed air flotation has been used to harvest Chlorella saccharophila (Alhattab et al., 2019). Flotation is often combined with flocculation to enable harvesting of concentrated flocs. This is an efficient harvesting method with reported harvesting yields of $93.6 \%$ for S. obliquus by thermal flocculation and air flotation (Xue et al., 2019); or 80\% harvesting of Dunaliella salina by combining $\mathrm{NaOH}$-induced coagulation and DAF in the pre-industrial scale (Besson et al., 2019). Flotation has also been combined with bioflocculation either by inducing exopolysaccharides production in A. plantensis with more than $90 \%$ harvesting efficiency (Vergnes et al., 2019); or bioflocculant produced from Cobetia marina for the flocculation-flotation of C. vulgaris also with higher than $90 \%$ efficiency (Lei et al., 2015).

Besides air, flotation can also be achieved by other gases such as ozone. The harvesting efficiency reported for an ozone dosage of $0.23 \mathrm{mg} \mathrm{mg}^{-1}$ of dried biomass was $79.6 \%$. Although not so efficient, ozonoflotation simultaneously pretreats the microalgae cells and increases the lipid extraction yields (Velasquez-Orta et al., 2014). Ozone reduces the microalgae carbohydrate and protein content due to cell lysis and partial release of these molecules in the medium. Denaturation of these proteins leads to foaming that acts as a surfactant and aids flotation (Nava Bravo et al., 2019). Indeed, the addition of surfactants like cetyl trimethyammonium bromide (CTAB), has verified the beneficial effect of foaming on flotation. Foam facilitates microalgae cell attachment to the air bubbles by modifying the hydrophobicity of the bubble surface. The surfactant's introduction could modify the extracted lipids chemical composition, possibly due to increased extraction of lipids from the cell membrane's lipid bilayer (Coward et al., 2014). The heat-induced flotation of Scenedesmus dimorphus at $85{ }^{\circ} \mathrm{C}$ has been proposed as a method for the utilization of heat from off-gases of industrial processes, with harvesting efficiency around 80\% (Laamanen and Scott, 2017).

\subsection{Membrane filtration}

Membrane filtration, batch or continuous, is a very common harvesting method that can be employed as dead-end with vertical flow across the membrane, or as tangential filtration where the flow is parallel to the membrane surface (Hung and Liu, 2018). Membrane material can be ceramic (Jana et al., 2018) or polymer (Zhao et al., 2016), and the process can be microfiltration (Kim et al., 2019) or ultrafiltration (Zhang et al., 2019), with membrane pore sizes $10 \mu \mathrm{m}-0.1 \mu \mathrm{m}$ and $0.1 \mu \mathrm{m}-0.01 \mu \mathrm{m}$, respectively. Molecule retention rate depends not only on membrane pore size but also on their chemical nature (polymeric, ceramic etc.).

Nylon membrane filtration is a very common filtration method. Gravity-driven dead-end filtration through $5 \mu \mathrm{m}$ nylon membranes was enough to achieve $>90 \%$ harvesting efficiency of A. platensis cultures. Pumped filtration additionally increased the filtration flux up to $20 \mathrm{~m}^{3} \mathrm{~m}^{-2} \mathrm{~h}^{-1}$ enabling a faster process (Cuellar-Bermudez et al., 2019). The flux of typical membrane filtration processes can be considerably smaller. For example, in the harvesting of Arthrospira sp. with ceramic microfiltration and 
ultrafiltration membranes, fluxes of $230 \mathrm{~L} \mathrm{~m}^{-2} \mathrm{~h}^{-1}$ and $93 \mathrm{~L} \mathrm{~m}^{-2} \mathrm{~h}^{-1}$ were reported, respectively (Jana et al., 2018).

For marine microalgae, growth medium salinity can have detrimental effects on harvesting efficiency by tangential-flow membrane filtration. Small increases in salinity of Picochlorum sp., and Tetraselmis sp. growth medium significantly increased membrane fouling and reduced the permeate flux and microalgae concentration factor, at the same time increasing the process energy requirements (Das et al., 2019). Membrane filtration performance is also influenced by the culture's growth phase. For example, harvesting of Scenedesmus acuminatus at the latter growth stages through ultrafiltration membranes increased flux from $97 \mathrm{~L} \mathrm{~m}^{-2} \mathrm{~h}^{-1}$, to $131 \mathrm{~L} \mathrm{~m}^{-2} \mathrm{~h}^{-1}$ leading to faster processing by $36 \%$. This was caused by the reduction of the average molecular weight of algogenic organic matter (AOM) secreted by the cells in the latter stages. The high molecular weight content of AOM (higher than 50 $\mathrm{kDa}$ ) decreased from $50 \%$ in the exponential phase to $42 \%$ in the stationary and $26 \%$ in the declining phase. As the high molecular weight fraction of AOM has the greatest membrane fouling potential its reduction led to minimized membrane fouling and increased flux. However, algogenic organic matter negatively impacted the process efficiency through enhanced fouling at all stages of ultrafiltration (Ye et al., 2019). Fouling is the major problem of membrane harvesting as it can negatively impact the process performance, reducing flux and increasing energy requirements for efficient harvesting (Elcik and Cakmakci, 2017). Regarding the effect of different types of AOM on fouling, it was found that polysaccharides excreted by the microalgae cells in the medium were related to reversible membrane fouling, whereas deposition of excreted protein led to irreversible membrane fouling (Jiang et al., 2018). Other soluble microbial metabolism products such as humin-like substances also contribute to irreversible membrane fouling (Wu et al., 2018; Zhao et al., 2017).

Fouling can be dealt with by adding surfactants like CTAB that remove hydrophilic and high molecular weight foulants and additionally lead to electrostatic microalgae cells neutralization allowing for more efficient dewatering (Taghavijeloudar et al., 2019). Alternatively, it can be prevented by the designing of antifouling membranes (Elcik et al., 2017), e.g. containing novel materials such as carbon nanotubes that improve membrane hydrophilicity (Khairuddin et al., 2019). Another approach is the introduction of local turbulence. This was achieved by a membrane module with a cylinder with holes at its center that created turbulent jets ejecting the feed into the membrane surface in a perpendicular direction. When used for the microfiltration of C. vulgaris, at a speed of $7 \mathrm{~L} \mathrm{~min}^{-1}$ fouling was reduced by $126 \%$ compared to conventional type modules such as hollow fiber membrane (Kim et al., 2019). Application of a shearing vibration is also able to reduce both reversible and irreversible fouling (Zhao et al., 2018, 2017). Cake layer formation of the filtered microalgae cells also contributes to fouling and increased membrane resistance (Wu et al., 2018). Introduction of rigid particles both in dead-end and crossflow filtration, as in the case of Chlorella sp. harvesting, can reduce the cake resistance and increase the flux and the membrane performance (Hung and Liu, 2018). Introduction of flocculants during the ceramic membrane filtration (both micro- and ultra-) of Arthrospira sp. also reduced fouling. This is caused as flocculation leads to the formation of larger size particles and reduces their ability to enter the membrane matrix (Jana et al., 2018). Indeed, membrane filtration is often used in combination with flocculation due to the synergy of the two methods (Sahoo et al., 2017; Shi et al., 2017).

\section{Table 4}

\section{Pretreatment of microalgae \& Extraction of target molecules}

\subsection{Physical methods}

\subsubsection{Milling}

Milling is one of the most promising methods for cell disruption of microalgae. Although it has been studied in various setups and sizes such as lab scale vortex milling (Araya et al., 2014) and pilot scale ball milling (Balasundaram et al., 2012), bead milling has been the most studied method. Typically, 
bead milling uses discs or rings to set in motion the grinding elements inside the milling chamber (Günerken et al., 2015a). Several disruption mechanisms are possible during bead milling. Shear stress due to acceleration of beads towards the mill wall, shear due to centrifugal acceleration of the mill wall, and due to collision of cells with beads due to differences in velocities (Kwade, 1999). The main mechanism of cell disruption is the third, ie cell disruption occurs through beads collisions because of velocity gradients in tangential direction near the stirring disks (Balasundaram et al., 2012; Hennart et al., 2009; Kwade, 1999) leading to combinations of cleavage, fracture and abrasion of cells or particles depending on particle size (Hennart et al., 2009). For large particles of around $15 \mu \mathrm{m}$ particles disintegration occurs through cleavage and fracture, for medium size particles of around $0.8 \mu \mathrm{m}$ through cleavage and abrasion, and for small particles only through cleavage (Hennart et al., 2009). Indeed, the disintegration of Nannochloropsis sp. in a bead mill, has revealed that larger size cell fractions are disintegrated via impact and compression - correlated to fracture and cleavage- and smaller fractions via shear forces more related to abrasion (Figure 4) (Pan et al., 2017).

Table 5

Figure 4

Since beads transfer energy to the cells their size plays a critical role in process efficiency. Decreasing the bead size from $1 \mathrm{~mm}$ to $0.3 \mathrm{~mm}$ improved the protein release kinetics of $N$. oleoabundans and $C$. vulgaris but the effect on the protein yield was less profound (Postma et al., 2017). In the same work the kinetics of carbohydrate release from $C$. vulgaris peaked at a bead size of $0.4 \mathrm{~mm}$ and an optimum carbohydrate release yield of approximately $65 \%$ was achieved. Bead size did not significantly affect cell disintegration, protein and carbohydrate release of Tetraselmis suecica in the same study, indicating a weaker cell wall (Postma et al., 2017). Protein release of $99 \%$ for T. suecica with a bead size of 0.3 $\mathrm{mm}$ was achieved at $400 \mathrm{sec}$ of processing time where a plateau is observed. Maximum carbohydrate release did not reach a plateau and was only observed at the end of the experiment, i.e. $900 \mathrm{sec}$ of processing time (Postma et al., 2017). Small bead size also improved the kinetics of Nanochloropsis pretreatment in a turbine mill (Pan et al., 2017). More than $90 \%$ cell disruption ${ }^{1}$ was achieved at 25 min with 0.3-0.4 mm beads, whereas $45 \mathrm{~min}$ were required for a similar result with $0.8-1.0 \mathrm{~mm}$ size. A further increase of bead size to $1.8-2.0 \mathrm{~mm}$ led to a dramatic drop in the mill performance $(65 \%$ cell disruption at $55 \mathrm{~min}$ ). Optimal bead sizes for the disruption of Chlorella strain P12 with a $4.3 \mu \mathrm{m}$ cell diameter, depended on the type of instrument used (Doucha and Lívanský, 2008). An optimal bead diameter of 0.3-0.5 mm was found for the Dyno-Mill and LabStar LS 1 bead mills, whereas the optimal bead diameter for the homogenizer MS 18 was $0.5-0.7 \mathrm{~mm}$ (Doucha and Lívanský, 2008). However, $1.3 \mathrm{~mm}$ glass beads were optimum for the bead milling of P. cruentum leading to a cell disintegration efficiency of 50\% (Montalescot et al., 2015). It is clear from the above that bead size alone cannot efficiently describe the process; other factors, such as the bead density affect the disruption efficiency. Beads with higher densities has been shown to perform better because they can tranfer higher energy to the cells (Hopkins 1991).

The milling chamber fill ratio is another important parameter. For $C$. vulgaris, increasing the chamber filling ratio had a positive effect on milling efficiency. For example, when using $\mathrm{ZrO} 2$ beads of $0.3 \mathrm{~mm}$ diameter in homogenizer MS 18, increasing the filling ratio from $60 \%$ to $75 \%$ and $80 \%$ increased cell disintegration from $65 \%$ to $83 \%$ and $85 \%$ respectively (Doucha and Lívanský, 2008). Similarly, when using $\mathrm{ZrO}_{2}$ beads $0.3-0.4 \mathrm{~mm}$ in the Dyno-Mill KD $20 \mathrm{~S}$ increasing fill ratio from $75 \%$ to $85 \%$ increased cell disintegration from $75 \%$ to $83 \%$ (Doucha and Lívanský, 2008). For $P$. cruentum increasing the filling ratio from $35 \%$ to $65 \%$ not only improved cell disruption, but also led to a shift in the optimum bead size from $1.3 \mathrm{~mm}$ to $0.65 \mathrm{~mm}$ (Montalescot et al., 2015). Continuous bead milling can be performed in single and multi-pass operation and the flow rate can also affect the performance. Usually increasing the flow rate reduces cell disintegration efficiency, by reducing the residence time in the milling chamber (Doucha and Lívanský, 2008; Montalescot et al., 2015). For example, increasing the feed rate from 12

\footnotetext{
${ }^{1}$ As determined by microscopic counting, in a hemocytometer, of intact cells before and after disintegration
} 
$\mathrm{Kg} \mathrm{h}^{-1}$ to $18 \mathrm{Kg} \mathrm{h}^{-1}$ reduced cell disintegration from $92 \%$ to $70 \%$. Energetically, it is evident that an optimized process with the shortest duration of treatment is desired and a compromise on the disruption ratio may need to be reached.

During bead milling cell disruption ${ }^{2}$ follows first-order kinetics (Doucha and Lívanský, 2008). Disintegration rates of $N$. gaditana show a sharp increase in the initial minutes and a plateau of $95 \%$ disintegration is reached at around $20 \mathrm{~min}$ (Safi et al., 2017a). Protein release in the same work reached a 50\% yield plateau at around $8 \mathrm{~min}$, suggesting that full cell disruption is not always required for efficient extraction of targeted molecules. For T. suecica the kinetics of cell wall disruption and protein release are identical and reach a $99 \%$ plateau after $6.7 \mathrm{~min}$. A similar carbohydrate release on the other hand is achieved after 15 min without reaching a plateau (Postma et al., 2017).

641

642

643

644

645

646

647

648

649

650

651

652

653

654

655

656

657

658

659

660

661

662

663

664

665

666

667

668

669

670

671

\section{2}

673

674

675

676

677

Increasing the solids content of the microalgae biomass slurry has a positive effect both on the yield of extraction and the process energy consumption up to a point. After that threshold the process becomes inefficient. For the extraction of lipids from Schizochytrium this limit was $50 \mathrm{~g} \mathrm{~L}^{-1}$ of biomass (Byreddy et al., 2016), and the disruption of Nannochloropsis cells became inefficient after a $18 \%$ volume of cell concentration (Pan et al., 2017). Assuming a near water cell density (Mathimani and Mallick, 2018) and a $10 \%$ biomass dry weight content, the $18 \% \mathrm{v} / \mathrm{v}$ can be estimated at around $2 \% \mathrm{DW}$, a surprising low concertation limit for the process. On the other hand, the extraction of water-soluble protein from Nannochloropsis gaditana, was energy efficient at $100 \mathrm{~g} \mathrm{~L}^{-1}$ but with around $50 \%$ protein yield (Safi et al., 2017a).

Besides bulk molecules such as lipids and carbohydrates, bead milling pretreatment can improve the yields of high-value molecules found in microalgae. In the lab scale, bead milling of A. platensis biomass in 4 cycles of $25 \mathrm{sec}$ at $30 \mathrm{~Hz}$, allowed almost $100 \%$ extraction of proteins and phycocyanin at $46 \mathrm{~g} 100$ $\mathrm{g}^{-1}$ biomass, and $95 \mathrm{mg} \mathrm{g}^{-1}$ biomass, respectively (Jaeschke et al., 2019). Bead milling pretreatment has also been used in lutein extraction from Scenedesmus almeriensis. When the dry biomass was treated for $5 \mathrm{~min}$, followed by an alkaline treatment and hexane extraction around $50 \%$ of lutein extraction yield was achieved. Addition of alumina powder in the biomass at 1:1 ratio acted as an extra disintegrating agent and increased lutein yield to $98 \%$ (Cerón et al., 2008). Bead milling of $C$. vulgaris for $1 \mathrm{~h}$ allowed yields of 50\% chlorophyll and $30 \%$ carotenoids extracted with supercritical $\mathrm{CO}_{2}$ and ethanol as a cosolvent (Safi et al., 2014). B-phycoerythrin, a natural high-value pigment was obtained from Porphyridium cruentum at a yield of $1.35 \mathrm{mg} \mathrm{g}^{-1}$ of wet biomass after bead milling (Ruiz-Ruiz et al., 2013). Although these results are promising, bead milling pretreatment was used in combination with other treatments, such as freeze drying of the biomass, alkaline pretreatment, and addition of alumina powder as a second disintegration agent. Such steps would increase complexity and cost of an industrial process and their economic and energetic viability would have to be assessed.

In the end, bead milling is a very complex process and many more parameters, like bead density, agitation speed, agitators design, and solid content of biomass can affect the outcome. The microalgae cell wall robustness is also a critical factor as it can vary between very weak like Porphyridium cruentum to very tough like Nannochloropsis oculata (Montalescot et al., 2015). Therefore, optimization can be tedious but also very precise if all parameters are carefully considered. The applicability of statistical design of experiments to such optimisation is evident.

\subsubsection{High-pressure homogenization (HPH)}

High-pressure homogenization (HPH) is typically used for emulsification purposes but is also suitable for the large-scale disruption of microalgae cells (Günerken et al., 2015a). Typically, a cell suspension is pumped at high pressures through a valve, colliding with an impact ring and then exiting from the high-pressure area into the environment where a high-pressure drop occurs (Middelberg, 1995). Various mechanisms of cell breakage (Figure 5) have been proposed including: shear due to sudden pressure

\footnotetext{
${ }^{2}$ As measured by counting undisrupted cells before and after milling in a Bürker chamber
} 
drop, shear stress, cavitation and impingement of the cells to the surface of the valve at high velocities (Middelberg, 1995). Several of these mechanisms of cell disruption can occurr simultaneously and which one is prevalent may also be species dependent (Middelberg, 1995). However, in most cases cell disruption is caused by shear stress and pressure drop between the valve and the vessel, as well as cell impingement onto the valve walls (Halim et al., 2012). The impingment stress was reported as being proportional to the operating relative pressure in some types of homogenisers (Chisti and Moo-Young, 1986). As pressure drop is one of the main cell-breaking mechanisms, the system operating pressure is critical for process performance (Balduyck et al., 2018; Halim et al., 2012; Onumaegbu et al., 2018; Samarasinghe et al., 2012). Increasing the pressure in the HPH of Chlorella sp. from 250 to 1400 bar increased cell rupture ${ }^{3}$ from $10 \%$ to $80 \%$ (measured by counting undisrupted cells before and after HPH in a Neubauer haemocytometer chamber) and subsequently the recovered lipids from $20 \%$ to $100 \%$ (Yap et al., 2014). Similarly, in the HPH treatment of Desmodesmus sp. F51 increasing the pressure from 689.5 to 2758 bar increases the release of carotenoids from around $0.02 \mathrm{mg} \mathrm{g}^{-1}$ to around $0.28 \mathrm{mg} \mathrm{g}^{-1}$ and the release of chlorophylls from around $0.01 \mathrm{mg} \mathrm{g}^{-1}$ to almost $1.5 \mathrm{mg} \mathrm{g}^{-1}$ (Xie et al., 2016). Complete disruption of $N$. gaditana cells occurred at 1500 bar. However, the protein release had already peaked at a much lower pressure (1000 bar), with a yield of 50\%, indicating that partial cell breakage is enough for the sufficient extraction of desired compounds (Safi et al., 2017a). As with other disruption and extraction methods, the method's influence on the target compound degradation is an important quality factor to consider during a biorefinery process.

\section{Figure 5}

The number of passes also has a positive impact on HPH extraction yields (Balduyck et al., 2018; Samarasinghe et al., 2012). Increasing the number of passes from 1 to 4 increased carotenoid release from Desmodesmus sp. F51 from around $0.28 \mathrm{mg} \mathrm{g}^{-1}$ to around $0.42 \mathrm{mg} \mathrm{g}^{-1}$, and chlorophyll release from $1.5 \mathrm{mg} \mathrm{g}^{-1}$ to $2.4 \mathrm{mg} \mathrm{g}^{-1}$ (Xie et al., 2016). Five passes were optimal for release of carbohydrates and proteins from dilute solutions of $C$. vulgaris treated at 1500 bar (Carullo et al., 2018). After five passes of Chlorococcum sp. cells more than $90 \%$ disruption was achieved (Halim et al., 2012). Increasing the number of passes to 6 had a positive effect on both the total protein and reducing sugars extraction yields from HPH treated $N$. oculata (Shene et al., 2016). Pretreatment of Nannochloropsis sp. with HPH at $150 \mathrm{MPa}$ required 6 passes to maximize extraction of green and red pigments, as deduced from increases in spectral intensities of the extracts at $415 \mathrm{~nm}$ and $620 \mathrm{~nm}$, respectively (Grimi et al., 2014). In general, HPH exhibits a first order decrease of cell disruption rate after each passage through the homogenizer (Halim et al., 2012). The rupture of Nannochloropsis sp., Chlorella sp. and T. suecica cells followed an exponential decay as a function of the number of passes (Spiden et al., 2013).

Smaller effects on HPH performance were attributed to cell concentration and culture stress level (Samarasinghe et al., 2012). Increasing the cell concentration of Desmodesmus sp. F51 from 2 and up to $90 \mathrm{~g} / \mathrm{L}$ did not affect the particle size distribution of HPH treated cells nor the release of carotenoids and chlorophylls (Xie et al., 2016). Increasing the cell concentration of $N$. oculata from $1.78 \%$ up to $8 \%$ w/w had little effect on the yield of lipids extracted (Shene et al., 2016). Indeed, it was found for Nannochloropsis sp. that important processing parameters such as flow rate, power draw and disruption efficiency were independent of cell concentration up to $25 \% \mathrm{w} / \mathrm{w}$ (Yap et al., 2015). As $25 \%$ is a typical concentration target of many harvesting/dewatering methods the ability to effectively break cells at these concentrations makes HPH a potential method for industrial microalgal cell disruption.

The method is also affected by the microalgae species biological properties. More specifically by cell wall toughness and its resistance to disruption. For example, only 170 bars are enough to break $T$. suecica cells, whereas Chlorella sp. cells require 1070 bar, and Nannochloropsis sp. 2000 bar (Spiden et al., 2013).

\footnotetext{
${ }^{3}$ As measured by counting undisrupted cells before and after HPH in a Neubauer haemocytometer chamber
} 
Two major mechanisms of cell disruption are reported during ultrasonication. Generation of highpressure bubbles and their cavitation, which generates shock waves that cause high shear forces (Gerde et al., 2012; Günerken et al., 2015b; Soo Youn Lee et al., 2017). The additional effect of free radical generation and oxidative degradation of cells has also been reported (Gerde et al., 2012). Increasing ultrasonication power and treatment time have a positive effect on cell disruption (Greenly and Tester, 2015; Keris-Sen et al., 2014; Meng Wang and Yuan, 2015; B. Zhang et al., 2018). Increasing the power increases bubble generation but reduces pressure inside the bubbles (Wang and Yuan, 2016). Beyond the optimum power and time values, undesirable effects on released products can occur, such as oxidative degradation (Gerde et al., 2012), and reduction of fatty acids chain size and double bond saturation (Cheng et al., 2014). Increasing the frequency of ultrasonication, positively affects cell disruption. Optimum sonication frequency is species depended and should be determined for each microalgae species (Kurokawa et al., 2016). Application of a pulsed mode improved protein extraction yield from $C$. vulgaris FSP-E (Chia et al., 2019). The pulsed mode has many advantages such as energy input reduction, lower heat generation during treatment, hence reduction in the extracted protein denaturation. This is important as temperature during ultrasonication can reach as high as $93{ }^{\circ} \mathrm{C}$ if not controlled (de Farias Silva et al., 2020). Ultrasonication efficiency seems to be independent of cell concentration at low to medium concentrations (1.5 to $14.1 \mathrm{~g} \mathrm{~L}^{-1}$ ) (Gerde et al., 2012). At higher cell concentrations a significant reduction in disruption efficiency can occur (Greenly and Tester, 2015; Meng Wang and Yuan, 2015) and has been attributed either to increased viscosity or reduced energy input per cell (Meng Wang and Yuan, 2015). Cell disruption in ultrasonication follows first order kinetics. The constant of disruption rate is directly proportional to the power level and has a parabolic relationship to cell concentration (Halim et al., 2013).

\section{$748 \quad$ Figure 6}

749 Cell aggregate formation during flocculation adversely affects cell disruption by ultrasonication. Cell bubble generation and collapse (Wang et al., 2015). The formation of microalgae cell aggregates by flocculation can occur naturally or be induced during harvesting/concentration (Muylaert et al., 2017). As flocculation is one of the most efficient concentration methods of microalgae biomass, its negative effect on cell disruption by ultrasonication demonstrates that careful selection of all downstream processes is required when assembling multiple methods in the same process.

Ultrasonication performed poorly in many comparative studies of cell disruption methods. It was less effective compared to microwave, electroflotation and thermal treatment (Florentino de Souza Silva et al., 2014), microwave and thermal treatment (McMillan et al., 2013), High-Pressure Homogenization, sulfuric acid and bead beating (Halim et al., 2012), Pulsed Electric Field, and High-Pressure Homogenization (Grimi et al., 2014). For example, ultrasound was not effective when applied in the pretreatment of microalgae with a very resistant cell wall such as $H$. pulvialis cysts. Even at $600 \mathrm{~W}$ for $30 \mathrm{~min}$ at $20 \mathrm{kHz}$ frequency and pulses $1 \mathrm{sec}$ on $3 \mathrm{sec}$ off a very low $12 \%$ astaxanthin yield was observed (Liu et al., 2018). In another study $80 \%$ extraction efficiency of astaxanthin was achieved only when ultrasound pretreatment of the $H$. pluvialis biomass was performed in a $2 \mathrm{M}$ sodium hydroxide solution (Haque et al., 2016). Although careful optimization of all these methods is required before safe conclusions can be drawn, it seems that ultrasonication is not a very effective method for cell disruption. It also suffers from the inability to handle large cell concentrations. Despite that, it can be useful in combination with other methods as it can enhance the disruption efficiency of other pretreatment methods. This will be discussed in following sections.

\subsubsection{Pulsed Electric Field}

Pulsed Electric Field is based on the exposure of microalgae cells to an intense electric field for very short durations (pulses). When the applied electric field is above a threshold it can induce reversible or irreversible pores creation (electroporation) on the cell membranes. Irreversible electroporation can 
facilitate intracellular material extraction (Figure 7) (Luengo et al., 2015). The microalgae suspension must not contain ions in order to be non-conductive. The medium of marine microalgae that contains significant salt concentrations, must be removed before PEF treatment, for example by electrodialysis, or cell washing and resuspension, increasing process steps, cost and energy. PEF is therefore more suitable for freshwater microalgae treatment (Günerken et al., 2015b). The cell membranes permeabilization (electroporation) is dependent on the electric field energy (Carullo et al., 2018). The main effect of PEF is pore creation in the cell membranes and does not lead to total cell disruption and cellular debris generation (Carullo et al., 2018). Temperature increase during PEF treatment is generally small (Picart and Cheftel, 2003), for example during PEF treatment of $C$. vulgaris the sample temperature increased from $20^{\circ} \mathrm{C}$ to $38^{\circ} \mathrm{C}$ depending on the operating parameters; the effect of this temperature increase on the yield of extracted proteins and their functionality were not investigated (Scherer et al., 2019). When very high treatment intensities were applied, e.g. higher than $35 \mathrm{kWh} \mathrm{m}^{-3}$ in the PEF treatment of Synechocystis PCC 6803, it led to limited cell disruption (approx.10\%), while the cell majority (around 87\%) remained intact but with damaged membranes (Sheng et al., 2011).

\section{Figure 7}

PEF efficiency is affected by the microalgae culture's growth state and cell size. Larger cells are more susceptible to electroporation, whereas smaller cells are more resistant (Safi et al., 2017a). The large size of $H$. pulvialis cells $(20 \mu \mathrm{m})$ may, therefore, have aided PEF treatment, as a $96 \%$ astaxanthin extraction efficiency, using ethanol, was reported (Martínez et al., 2019). In contrast, the small cell size $(2-8 \mu \mathrm{m})$ of $C$. sorokiniana (Azaman et al., 2017) may have a negative impact on PEF treatment. For example, a yield of $3.25 \mathrm{mg} \mathrm{g}^{-1} \mathrm{DW}$ of pigments was achieved after PEF treatment, an improvement of $14 \%$ compared to the untreated sample (Leonhardt et al., 2020). Both species have rigid cell walls; $H$. pulvialis with a resistant algaenan layer, and $C$. sorokiniana a glucosamine rich and chitin-like layer. Cell wall rigidity can lead to inefficient extraction of molecules even at very high intensities and number of pulses (Safi et al., 2017a). This has been confirmed by comparing the PEF efficiency between a wild type strain of $C$. reinhardtii with cell wall and a mutant without cell wall (T Lam et al., 2017). A dramatic increase on protein extraction yields was observed in the cell wall free mutant even at very low power intensities. The effect could be repeated when the wild strain's cell wall was removed by enzymatic digestion.

Due to its relatively mild effect on cell integrity, PEF is often described as a mild or selective pretreatment method that can specifically target intracellular molecules, such as low molecular weight proteins and carbohydrates (Carullo et al., 2018; Safi et al., 2017a; T Lam et al., 2017). Although a significant increase in the release of water-soluble intracellular components is induced by PEF, their yields are relatively low (around or below 10\%) even at relatively high intensities indicating only partial success of PEF as a pretreatment method. In all these studies the treated microalgae had a full cell wall, that may explain the low yields obtained.

The low levels of lipids released with PEF from Auxenochlorella protothecoides cells is possibly because the generated pores are more permeable to smaller water-soluble molecules rather than the larger lipid droplets (Eing et al., 2013). This can enable an easier separation of carbohydrates and proteins from lipids that could be sequentially extracted by organic solvents (Eing et al., 2013). PEF treatment of wet Synechocystis PCC 6803 biomass increased the lipid yields and lowered the solvent to biomass ratio from 10 to 5 as it allowed the penetration of isopropanol through the pores to extract lipid molecules (Sheng et al., 2011). The kinetics of lipid extraction from Ankistrodesmus falcatus with the green solvent ethyl acetate were relatively slow and around $2 \mathrm{~h}$ were required for the process to plateau at a yield of around $2500 \mu \mathrm{g} \mathrm{L}^{-1}$. After PEF treatment the lipid extraction was almost time independent as increasing extraction time between 0 and $2 \mathrm{~h}$ lead to a marginal increase in lipids from $9000 \mu \mathrm{g} \mathrm{L}^{-1}$ to almost $9800 \mu \mathrm{g} \mathrm{L}^{-1}$ (Zbinden et al., 2013). Although a yield increase is also shown, extraction experiments with and without PEF treatments were performed with different microalgae samples, and therefore the effect of PEF on the yield remains inconclusive (Zbinden et al., 2013). Similarly, the PEF treatment of A. protothecoides increased lipid extraction with 100\% ethanol from around 30 to around $220 \mathrm{mg} \mathrm{g}^{-1}$ of dry weight biomass (Eing et al., 2013). 


\subsubsection{Drying}

Drying is the decrease of microalgae biomass moisture content to around $10 \%$. It is a post harvesting and dewatering process aims at improving the stability of the final product. The main challenges of drying are the long time and high energy input required and the associated cost increase. The simplest drying technology is sun drying as it requires low capital and operating cost (Ansari et al., 2018). However, long process time is needed for efficient water removal from the sample, even as high as 72 $\mathrm{h}$ (Guldhe et al., 2014). Sun drying can decrease the extraction yield of biomolecules from microalgae compared to untreated biomass (Ansari et al., 2018) possibly due to degradation reactions or due to consumption from microbial contamination during the long drying times. Convection drying utilizes hot air to remove moisture from the biomass. It has shorter process times, up to $12 \mathrm{~h}$ and leads to less biomolecule degradation compared to sun drying (Ansari et al., 2018). The lipids extracted from oven dried biomass has slightly lower saponification and acid values compared to sun dried biomass, indicating lower free fatty acid values.

Freeze drying, also called lyophilization, is a very mild drying method that does not destroy the biomolecules of the biomass samples (Ansari et al., 2018). It is based on the sublimation of ice from a frozen sample into the vapor phase inside a vacuum. Freeze-drying can have long process time, usually around $24 \mathrm{~h}$. Due to the requirement for deep freezing of the sample, and maintaining a vacuum and a negative temperature in the freeze-drier, it is the most energy consuming and expensive method, typically 1 or 2 orders higher than the rest (Table 6). Its long process time, high energy requirement and high cost should limit application of freeze-drying for very sensitive and high-value products. Spray drying is based on heating of the microalgae slurry as it passes through a spraying nozzle which leads to the formation of a dry powder as the moisture rapidly evaporates from the sample droplets. |Samples of freeze-dried $P$. tricornutum cells were found more prone to lipolysis, and spray dry lipolysis ed samples were more sensitive to oxidation caused by the reduction of the antioxidant carotenoid content (Ryckebosch et al., 2011). Drum drying is a mature drying technology with applications in the food industry. It has lower energy requirements and costs compared to spray drying (Table 6) but can process only up to $1000 \mathrm{Kg} \mathrm{h}^{-1}$ of sample compared to the $10000 \mathrm{Kg} \mathrm{h}^{-1}$ maximum upper limit for spray drying. This big difference in processing capacity if favor of spray drying can compensate for the slightly higher energy and operational costs, and make spray drying an attractive drying method (Fasaei et al., 2018).

Drying microalgae before extraction of valuable components clearly adds to the treatment cost while greatly increasing the extraction efficiency. Recent technology on extraction from wet biomass is promising but the cross-over point where the lower extraction efficiency of wet extraction can be accepted has not been reached.

Table 6

\subsection{Chemical methods}

\subsubsection{Hydrothermal}

Cell wall disruption via hydrolysis is variably referred in the literature as water bath treatment (McMillan et al., 2013), autoclave (Florentino de Souza Silva et al., 2014), hydrothermal pretreatment (Xiao et al., 2019) and steam explosion (Lorente et al., 2018). In all these variations two main mechanisms are thought responsible for the microalgae cell disruption; cell wall rupture due to internal pressure buildup from the heating, and hydrolysis of cell wall components. Due to this dual effect the method can be classified both as physical and chemical. At lower temperatures where hydrolytic reactions of the cell wall components are not yet favoured disruption due to internal pressure build-up is the prevailing mechanism (McMillan et al., 2013). Even at such mild treatment conditions, e.g. $90{ }^{\circ} \mathrm{C}$, for 20 min, 
extensive disruption ${ }^{4}$ of $87 \%$ for $N$. oculata cells was observed. At higher temperatures the hydrolysis reactions of the microalgae structural components such as the cell wall polysaccharides becomes significant, leading to the production of monomeric sugars and the reduction of cell wall integrity (Xiao et al., 2019). In the steam explosion variation of the method the microalgae slurry is heated under pressure with saturated steam to the desired temperature, and at the end of the reaction the slurry undergoes rapid decompression (explosion) through a release valve (Lorente et al., 2017). The rapid change in pressure can create an additional cell disruption effect.

The hydrothermal method has been extensively used to pretreat lignocellulosic biomass, in order to remove hemicellulose (Garrote et al., 1999) and enhance the enzymatic digestibility of cellulose (Nitsos et al., 2013), and to subsequently increase the bioethanol (Ruiz et al., 2012) and biomethane (Antwi et al., 2019) production yields. The method can also be applied to microalgae that have a carbohydrate cell wall composition. For example, it is very efficient in the release of carbohydrates from microalgae. Carbohydrate yields of $44 \%$ of total carbohydrate content from $N$. gaditana (Lorente et al., 2015), 60\% (Fu et al., 2018) and $80 \%$ (Xiao et al., 2019) from C. pyrenoidosa, $97 \%$ from C. vulgaris (Xiaojian et al., 2017) have been achieved. At prolonged pretreatment times the released biomolecules can further react to form degradation products (Córdova et al., 2018), such as furans and organic acids from the dehydration (Horvat et al., 1985; Mussatto and Roberto, 2004; Palmqvist and Hahn-Hägerdal, 2000), or from Maillard reactions (Fu et al., 2018) of the carbohydrates with amine containing groups. Bioethanol production from hydrothermally treated Schizocytrium sp. slurry after enzymatic hydrolysis reached $90 \%$ of the theoretical maximum ethanol yield (Kim et al., 2012). Hydrothermal pretreatment increased the yield of biogas from the anaerobic digestion of microalgae biomass by $11 \%$ (Martín Juárez et al., 2018) and 28\% (Passos et al., 2015) for mixed microalgae biomass and 57\% for pure C. pyrenoidosa (Xiao et al., 2019). The production of toxic compounds due to the released molecules degradation during steam explosion led to a reduction of biomethane yield due to anaerobic digestion inhibition (Córdova et al., 2018).

\section{Table 7}

Two stages can be observed during hydrothermal treatment of microalgae based on the temperature regimes. Initially and up to $100{ }^{\circ} \mathrm{C}$ the release of high molecular weight intracellular components such as starch and protein occurs; the gelatinization of starch and denaturation of proteins can lead to an increase in the medium viscosity; at $140-160^{\circ} \mathrm{C}$ the macromolecules are hydrolyzed into oligomers of lower molecular weight and the viscosity decreases (Chen et al., 2019a; McMillan et al., 2013). The microalgae slurries produced from hydrothermal pretreatment, exhibited shear thinning behavior, suggesting non-Newtonian fluid behaviour (Chen et al., 2018). The ability of viscosity reduction by increasing the temperature or the shear rate can be valuable as it would allow the processing of high biomass concentrations in downstream unit operations.

A kinetic study showed that the treatment temperature, time and pressure were the most important parameters of hydrothermal pretreatment in terms of carbohydrate release, whereas temperature was the main factor that controlled protein release (Xiaojian et al., 2017). This dependence of carbohydrate release on time and temperature is similar in the hydrothermal pretreatment of lignocellulosic biomass, due to the hydrolytic reaction that dominates it. To express the combined effect of time and temperature the severity factor $\left(\log R_{\mathrm{o}}\right)$ has been established in the hydrolysis of lignocellulosic materials, that can be calculated from the equation

\footnotetext{
${ }^{4}$ As measured by counting the number of intact cells treated after a specific time interval against those initially determined from the control, using a microscope
} 


$$
R_{o}=t * \exp \left(\frac{T_{(t)}-100}{14.75}\right)
$$

where, $t$ is the pretreatment time and $\mathrm{T}_{(\mathrm{t})}$ the pretreatment temperature for holding time $\mathrm{t}$.

It is possible that due to similarities in the chemical composition of carbohydrates in plants and microalgal cell walls, the equation can correlate the effects of microalgae pretreatment with time and temperature. Some evidence towards that can be seen in Table 7. Although the data points correspond to yields from different studies, with different microalgae species, e.g. C.vulgaris (Mendez et al., 2013), $N$. gaditana (Lorente et al., 2015) C. pyrenoidosa (Xiao et al., 2019), different mixing and heating régimes, e.g. stirring in reactor (Qu et al., 2018), lack of mechanical mixing in steam explosion (Lorente et al., 2015) and biomass concentrations ranging from $16 \mathrm{~g} \mathrm{~L}^{-1}$ (Mendez et al., 2013) up to $20 \% \mathrm{w} / \mathrm{w}$ (Qu et al., 2018)), the increase of biomolecules release or extraction yield with increasing severity can be clearly seen.

Significant protein release from hydrothermally treated microalgae biomass is also possible; $47 \%$ (Xiao et al., 2019) and 83\% (Fu et al., 2018) of protein was isolated from C. pyrenoidosa, and $76 \%$ from $C$. vulgaris (Xiaojian et al., 2017). Lower protein recovery (approx. 20\%) is observed at lower severity factor ( $\log R o$ ) values (approx. 2). As with carbohydrates, protein release is also well correlated to the treatment's severity factor. Cell wall disruption also allowed the subsequent extraction of lipids, with yields of $60 \%$ from $N$. salina (Lee and Han, 2015a), 68\% from C. vulgaris (Xiaojian et al., 2017) and $84 \%$ from Nannochloropsis sp. (Qu et al., 2018) reported. After the hydrothermal pretreatment of $C$. vulgaris it was shown that the lipids remained in the biomass and were not detected in the pretreatment liquid that was rich in carbohydrates and protein (Xiaojian et al., 2017). This may allow the selective separation of water-soluble molecules and lipids, in comparison to other cell disruption methods like bead beating that generate difficult to separate water-oil emulsions.

Other applications include the extraction of carotenoids from $H$. pluvialis at yields higher than $85 \%$ (Mendes-Pinto et al., 2001). Near complete extraction of astaxanthin was shown by hydrothermal disruption of $\mathrm{H}$. pluvialis cells at $200{ }^{\circ} \mathrm{C}$ for $10 \mathrm{~min}(\operatorname{logRo} 4)$ (Cheng et al., 2017). The chemicals released from hydrothermal treatment of $\mathrm{H}$. pluvialis at $200^{\circ} \mathrm{C}$ for $20 \mathrm{~min}(\log \mathrm{Ro} 4.2)$ showed significant antioxidant and antimicrobial activity. The antimicrobial activity was attributed to extracted short chain fatty acids, while the antioxidant activity was to vitamin E, penolics, as well as carbohydrate degradation products (Rodríguez-Meizoso et al., 2010). The extraction of phenolic compounds from Chlorella $s p$. by mild hydrothermal treatment is also possible. Treatment of Chlorella sp. biomass at a concentration of $20 \mathrm{wt}$. \% for $5 \mathrm{~min}$ at $163{ }^{\circ} \mathrm{C}(\operatorname{logRo} 2.6)$, yielded $58.73 \mathrm{mg}$ of gallic acid equivalent $\mathrm{g}^{-1}$ that exhibited significant antioxidant activity (inhibiting by $68.5 \%$ the DPPH radical) (Zakaria et al., 2017). Temperature had a significant effect on extraction yield. Increasing the temperature from $100{ }^{\circ} \mathrm{C}$ to 170 ${ }^{\circ} \mathrm{C}$ increased both the total phenolic content and the antioxidant activity of the extracts. Further increases of the temperature up to $250{ }^{\circ} \mathrm{C}$ led to a decrease of the phenolic content and antioxidant activity by almost $50 \%$, to levels comparable to those at $100^{\circ} \mathrm{C}$. (Zakaria et al., 2017). This was attributed to thermal degradation of the extracted phenolics. Increase of time from 5 to $20 \mathrm{~min}$ decreased phenolic content and antioxidant activity of the extracts by approximately $10 \%$ (Zakaria et al., 2017). Increasing the biomass concentration from $5 \mathrm{wt}$ \% to $20 \mathrm{wt}$. \% increased phenolic content by approx. $50 \%$. Antioxidant activity, however, peaked at $12.5 \mathrm{wt}$. $\%$ and remained almost constant up to $20 \mathrm{wt}$. \% of biomass concentration, but no explanation for this phenomenon was offered (Zakaria et al., 2017).

Hydrothermal treatment of biomass at very high temperatures (above $230{ }^{\circ} \mathrm{C}$-supercritical water) can lead to cellular structure disintegration through biomass carbonization, that can also be beneficial for lipid extraction (Kröger et al., 2018). At even higher temperatures (e.g. $260,300,340{ }^{\circ} \mathrm{C}$ ) the biomass undergoes hydrothermal liquefaction (HTL) and is directly converted to hydrothermal bio-oil that can be used as a biofuel (B. Zhang et al., 2018). This is no longer a pretreatment method but a direct conversion method of microalgae biomass into the final product. Its main advantages are that water removal is not required and that it is a single step process, but it is limited to biofuel production, and therefore maybe more suited for lower value microalgae or microalgae debris after the extraction of valuable molecules. 
Overall hydrothermal pretreatment has many advantages including lack of reagents other than water, ability to operate at high solids content, ability to pretreat a variety of microalgae species and ease of post treatment separation and fractionation of compounds. Careful optimization is required, to minimize degradation of valuable products due to the high temperatures employed. Another disadvantage is the energy input required for the reaction to take place, however, significant energy can be recovered by heat exchange (Chen et al., 2019b) and even solar heated hydrothermal reactors showed significant extraction yields minimizing energy requirements of the process (Xiao et al., 2019).

\subsubsection{Acid treatment}

The pretreatment of microalgae with dilute solutions of inorganic acids can be considered as a hydrothermal pretreatment variation. The rate of hydrolytic reactions at elevated temperatures in water, are enhanced by the acid catalyst's addition. High carbohydrate, lipid and protein yields can be achieved at lower temperatures and shorter reaction times. Acid concentration employed is usually between 1-5 $\%$ and temperatures between $110^{\circ} \mathrm{C}$ and $150^{\circ} \mathrm{C}$ have been reported; but the specific conditions must be tailored to the target molecules to be extracted. Sulfuric acid is most commonly used for acid pretreatment due to its low cost and efficiency. Other acids such as nitric acid have also been tested, but significant reduction in the yield has been observed at higher acid concentrations (Lee et al., 2014; Lee and Han, 2015b). This is probably a result of the nitric acid's oxidative action that would degrade the released molecules. Hydrochloric acid gave superior saccharification results compared to sulfuric acid and nitric acid at concentrations ranging from $0.2 \mathrm{M}$ to $2 \mathrm{M}$, in the hydrolysis of Hindakia tetrachotoma ME03 biomass (Onay, 2019).

A modified version of the severity factor $\left(\log R_{0}\right)$ from the hydrothermal pretreatment can be expressed in terms of time $(\mathrm{t})$, temperature $(\mathrm{T})$ and acid catalyst concentration (related to $\mathrm{pH}$ ). The Combined Severity Factor (CSF) is given by the equation:

$$
C S F=\log \left[t \exp \left(\frac{T-100}{14.75}\right)\right]-p H
$$

A good correlation between the process CSF and the carbohydrate release or the lipid extraction yields can be obtained (Table 8). For N. gaditana a carbohydrate yield of $50 \%$ was achieved at a CSF 0.4 and increased to $59 \%, 63 \%$ and $89.7 \%$ for CSFs of $0.75,1.0$ and 1.4, respectively (Lorente et al., 2015). The pretreatment of Chlorella sorokiniana and P. tricornutum at CSF of 1.4, leads to almost complete carbohydrate recovery yields (95\% and $96 \%$, respectively). The big advantage of the process is that these high carbohydrate extraction yields are achieved only after 5 min of pretreatment time. At higher CSFs of 1.87 both $N$. gaditana and C. sorokiniana showed reduced carbohydrate yields, at $69 \%$ (Lorente et al., 2017) and $79.2 \%$ (Lorente et al., 2018) respectively; possibly due to released sugar degradation. Released carbohydrates from microalgae have been used to produce bioethanol with increased yield compared to the untreated biomass (Choi et al., 2010; Ngamsirisomsakul et al., 2019). The degradation products generated from acid hydrolysis can lead to inhibition of fermentation-based microalgae valorisation processes (Martín Juárez et al., 2018). Pretreatment liquid neutralization may also be required as the low $\mathrm{pH}$ values can significantly reduce microbial growth.

\section{Table 8}

Lipid extraction yields remain relatively low $(<30 \%)$ below CSF values of 1.4, whereas lipid yields up to $88 \%$ are reported at CSF of 1.9 (Lee et al., 2014). This indicates that relatively high cellular wall degradation is required to enable efficient intracellular lipids solvent extraction Although the degree of cell disruption is not reported by the authors, it is possible that at these higher CSF' values where lipid extraction is efficient, extensive cell wall disruption has occurred. Optimal carbohydrate-hydrolysis and lipid-extraction yields seemed to occur in a very narrow parameter range (CSF values between 1.4 and 
2). This can lead to severe degradation of the released products even with minute changes in the process control. Moderate protein release around 50\% is also possible with CSF values of approximately 2 (Lorente et al., 2017).

Acid treatment has also showed promising results in extraction of high-value molecules. Astaxanthin extraction from $\mathrm{H}$. pluvialis by treatment with $4 \mathrm{M} \mathrm{HCl}$ at $70{ }^{\circ} \mathrm{C}$ for $60 \mathrm{~min}$ (CSF 1.5) achieved a yield of $80 \%$ (Liu et al., 2018). Lutein extraction yield of $3.5 \mathrm{mg} \mathrm{g}^{-1}$ C. pyrenoidosa biomass was achieved with $16 \% \mathrm{HCl}$ treatment for $41 \mathrm{~min}$ (Arun, 2017).

In general, dilute acid pretreatment is a very fast and efficient pretreatment method for the extraction of carbohydrates and lipids from microalgae. Application for extraction of high value molecules may also become possible in the future. However, due to the acids aggressive nature, careful pretreatment conditions optimization is required to avoid the extracted molecules degradation, especially the proteins, antioxidants, and pigments.

\subsubsection{Alkaline treatment}

Alkaline treatment involves biomass exposure to a basic aqueous medium at elevated temperature. Like acid hydrolysis, it can also be considered as a hydrothermal pretreatment variation with addition of a basic catalyst. A fundamental difference concerns the operatory condition of theses pre-treatments, especially adapted for lower temperatures, (below $120^{\circ} \mathrm{C}$ ), and longer treatment time that can span up to several days (Mahdy et al., 2014a). Alkaline pretreatment can target the hydrolysis of ester bonds and hydrogen bonds between polysaccharide and non-polysaccharide cell wall components, especially at lower temperatures (Costa and Plazanet, 2016). For this reason, it has been extensively used for the extraction of hemicellulose from lignocellulosic biomass. At low temperature microalgae alkaline pretreatment induces a mercerization-like effect accompanied by cell wall swelling and an improvement of protein extraction yields (Phong et al., 2018). At higher temperatures intramolecular glycoside bonds are also affected leading to the hydrolysis of cell wall and intracellular carbohydrates.

Like acid pretreatment the combined effect of time (t), temperature (T) and base catalyst concentration (pOH), can be expressed by a modified Combined Severity Factor (CSF') that is given by the equation:

The CSF' can describe the effect of pretreatment on the hydrolysis of carbohydrates, release of protein and lipid extraction from microalgae. Again, a narrow range of CSF' values (between 1.2 and 2.5) provides the optimal carbohydrate hydrolysis yields (80 to $100 \%$ ) that have been reported. Approximately $80 \%$ of total carbohydrates were recovered in the hydrolysates of H. tetrachotoma ME03 (Onay, 2019) and a mixed microalgae culture (Shokrkar et al., 2017) at CSF' 2.4 and 2.5, respectively. Complete carbohydrate recovery was possible for $C$. vulgaris ESP6 at a much lower CSF' of 1.3 (Liu et al., 2012). Protein release yields from a mixed extraction yield was moderate at $32 \%$, however very low $\mathrm{CSF}^{\prime}$ values were tested $\left(\mathrm{CSF}^{\prime}<-2.9\right)$. These values were obtained by pretreatment temperatures up to 75 ${ }^{\circ} \mathrm{C}$ and prolonged pretreatment times of up to $48 \mathrm{~h} ; \mathrm{CaO}$ (lime) was used as the alkaline catalyst. Similar results were found for the pretreatment of $C$. vulgaris with $42 \%$ protein yield at CSF' - 1.8 (Mendez et al., 2013). The extraction of lipids by enzymatic hydrolysis of alkaline pretreated Nannochloropsis sp. was comprehensively studied for a variety of temperature, time and $\mathrm{pH}$ pretreatment conditions (Wu et al., 2017). Alkaline treatment was followed by an enzymatic hydrolysis step with a cocktail of commercial enzymes (cellulase, protease, lysozyme, and pectinase). The results show a very good correlation with CSF'. Maximum lipid extraction yields were obtained at low CSF' values, between -0.9 and -0.3 , much lower compared to those required for maximum carbohydrate release shown above. They are also lower compared to the CSF values required for quantitative lipid extraction by acid pretreatment. This could be due to differences in cell wall resilience between species. Also, the results of this study 
are not directly comparable to the rest alkaline pretreatment studies as it employs an extra enzymatic hydrolysis process step, after alkaline treatment, leading to increased cell wall degradation and easier lipid extraction. Further increasing the severity beyond -0.3 leads to a reduction in the lipid yield, probably due to lipid degradation.

Alkaline pretreatment is also used to enhance the production of bio-methane from microalgae anaerobic digestion. The pretreatment of $C$. vulgaris and Scenedesmus sp. at low CSF' values led to marginal increases in the methane yield (20\% improvement at the base case) (Mahdy et al., 2014a). Similar results were obtained in the alkaline pretreatment of mixed microalgae culture at low CSF' $(0.24)$ that led to a $25 \%$ improvement of methane yield (Solé-Bundó et al., 2017). The $\mathrm{NaOH}$ pretreatment of $C$. vulgaris at CSF' -1.8 gave a 68.8\% methane yield (Mendez et al., 2013). $\mathrm{NaOH}$ pretreatment of mixed microalgae biomass significantly increased methane production from approximately $162 \mathrm{~mL} \mathrm{CH}_{4} \mathrm{~g}^{-1}$ of volatile

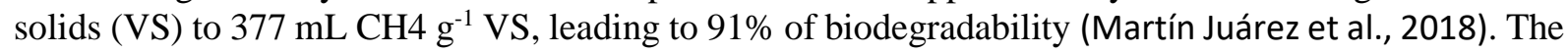
enhanced extraction of the carotenoid lutein from Scenedesmus almeriensis by alkaline pretreatment has also been studied (Cerón et al., 2008). The recovery yield can be related to CSF' over a very narrow range, between -2 and 0 with the maximum recovery of $90 \%$ achieved at -0.8 The rapid lutein yield decrease shows that optimization of parameters is critical for extraction of sensitive molecules to avoid loss through degradation reactions.

\subsubsection{Oxidative pretreatment}

\subsubsection{Ozonolysis.}

Exposure to oxidative agents can be a very aggressive treatment of biological materials. It has been traditionally used in the pulp and paper industry for pulp bleaching, as a more environmentally friendly alternative to traditional chlorine-based processes (Rounsaville and Rice, 1996). Bleaching is achieved by removing the residual and recalcitrant lignin that remains after the pulping process. It has also been applied as a pretreatment method of lignocellulosic biomass to enhance enzymatic hydrolysis (GarcíaCubero et al., 2009), and as a cell disruption method for treatment of microalgae (Keris-Sen and Gurol, 2017). As with pretreatment of lignocellulosic biomass, ozonolysis of microalgae cells can increase the enzymatic cell wall saccharification leading to $81 \%$ glucose yields. Pretreatment efficiency increases with the ozone dose administered up to a maximum and then gradually decreases. Low glucose yields at low ozone doses is attributed to insufficient cell wall disruption, whereas low yields at high ozone dosages is the result of carbohydrates degradation (Keris-Sen and Gurol, 2017). Thus, an ozone dose optimization is to be determined in order to improve the yield of glucose.

Exposure of microalgae cells to ozone could be performed by conventional bubbling of ozone or under pressure assisted ozonation with compression and decompression cycles (Huang et al., 2014). Ozonolysis leads to cell rupture and the release of intracellular material in the medium that is accompanied by measurable increases of total organic compounds, nitrogen and phosphorus. Increasing the ozone pressure as well as the number of compression and decompression cycles is beneficial for the lipid extraction; optimization of the two parameters led to $27 \%$ lipid yield ( $\mathrm{g} \mathrm{g}^{-1}$ biomass) (Huang et al., 2014). Two mechanisms of pretreatment were identified. Under conventional ozonation, oxidation increases cell wall permeability and cytoplasm release. In the pressure assisted system, compression increases dissolved gas inside the cytoplasm and during decompression gas expansion occurs. Repetition of the compression decompression cycle induces additional stress to the cells and increases disruption efficiency and lipid extraction yields (Huang et al., 2014).

Ozonation of the filamentous cyanobacteria A. platensis has been investigated in various ozone doses. At low ozone concentrations $\left(5-15 \mathrm{mg} \mathrm{L}^{-1}\right)$ the dominant effect observed was the filament's shear into smaller fragments. At higher ozone doses (up to $510 \mathrm{mg} \mathrm{L}^{-1}$ ) an increase in filament transparency accompanied by the release of intracellular organic material was observed; these cellular material subsequently formed clusters (Akao et al., 2019). Similar effects were observed in the ozonation of mixed microalgae cultures for the production of methane through anaerobic digestion (Cardeña et al., 
2017). At optimal ozonation pretreatment conditions a $66 \%$ increase in the methane yield was obtained. Under these conditions cells exhibited fragmentation in the cell walls due to oxidation leading to cell lysis and better access of hydrolytic enzymes from the anaerobic bacteria to the intracellular material (Cardeña et al., 2017). Ozonation pretreatment leads to significant increases in the oil extraction yield up to $100 \%$ in some cases (Lin and Hong, 2013).

\subsubsection{Hydrogen peroxide}

$\mathrm{H}_{2} \mathrm{O}_{2}$ is an alternative oxidizing agent for the pretreatment of microalgae with a similar mechanism to ozonation. Oxidation of mixed microalgae culture with $\mathrm{H}_{2} \mathrm{O}_{2}$ leads to biomass solubilization of $23 \%$ and a $173 \%$ increase in the methane production yield corresponding to $67 \%$ biodegradability (Martín Juárez et al., 2018). Astaxanthin extractability of $54.5 \%$ from $\mathrm{H}$. pluvialis was possible by treatment with $2 \mathrm{M}$ of $\mathrm{H}_{2} \mathrm{O}_{2}$ (Haque et al., 2016).

An alternative method to increase oxidation capacity is to combine the $\mathrm{H}_{2} \mathrm{O}_{2}$ with iron ions in order to induce Fenton-like reactions. The two chemicals react to create hydroxyl radicals $\left(\cdot \mathrm{OH}^{-}\right)$that attack the microalgae's organic molecules. The combined use of $\mathrm{H}_{2} \mathrm{O}_{2}$ with $\mathrm{FeSO}_{4}$ significantly increased lipid extraction efficiency from C. vulgaris to $78 \%$ of total lipids compared to $41 \%$ when $\mathrm{H}_{2} \mathrm{O}_{2}$ was used alone, (Steriti et al., 2014). A Fenton-like reaction with $\mathrm{FeCl}_{3}$ as the cell disruption reagent for lipid extraction from Chlorella sp. KR-1, was improved by simultaneous UV-irradiation of the reaction mixture. The unaided Fenton-like reaction yielded $80 \%$ of total lipids at $0.5 \% \mathrm{H}_{2} \mathrm{O}_{2}$. The UV-Fentonlike reaction experiment improved the lipid yield to $85 \%$ at a reduced $0.3 \% \mathrm{H}_{2} \mathrm{O}_{2}$ consumption (Seo et al., 2015a). The substitution of $\mathrm{H}_{2} \mathrm{O}_{2}$ with the persulfate ion $\left(\mathrm{S}_{2} \mathrm{O}_{8}{ }^{2-}\right)$ was also investigated. The persulfate ion reacted with $\mathrm{Fe}^{3+}$ to generate $\mathrm{SO}_{4}{ }^{-{ }^{-}}$and $\mathrm{S}_{2} \mathrm{O}_{8}{ }^{-{ }^{-1}}$ radicals instead of the $\cdot \mathrm{OH}^{-}$radicals of the typical Fenton reaction (Seo et al., 2016). The persulfate reagent at $2 \mathrm{mM}$ concentration led to improved lipid extraction yield $95 \%$, compared to $80 \%$ for $0.5 \%(\mathrm{v} / \mathrm{v}) \mathrm{H}_{2} \mathrm{O}_{2}$ at the same pretreatment conditions.

The aggressive nature of all the oxidative pretreatment reactions leads to chemical alterations of the targeted biomolecules. Most affected are the sensitive pigments like chlorophyll. The partial or complete destruction of chlorophyll in the oxidation pretreatment of microalgae samples has been reported for ozonation (Huang et al., 2014; Kamaroddin et al., 2016) and Fenton-like reaction pretreatments (Seo et al., 2015a, p.). Additionally, significant chemical changes are observed in the composition of the extracted lipids. These changes are mainly the significant increase of saturated and monounsaturated fatty acids and the reduction in polyunsaturated fatty acids. The Fenton pretreatment of C. vulgaris increased the saturated, monounsaturated and C18:2 fatty acids in the extracted lipid from $35 \%(\mathrm{w} / \mathrm{w})$ in the untreated sample to $80 \%(\mathrm{w} / \mathrm{w})$ after pretreatment. At the same time the content of polyunsaturated fatty acids in the cells pretreated by Fenton reaction was dramatically decreased from $60 \%$ to $20 \%$ (w/w) (Concas et al., 2015a). In another study of C. vulgaris pretreated by Fenton reaction the polyunsaturated fatty acids content decreased from $21 \%(\mathrm{w} / \mathrm{w})$ to $4.75 \%(\mathrm{w} / \mathrm{w})$ (Concas et al., 2015b). Similarly, the ozonation of $C$. vulgaris decreased the concentration of saturated fatty acids to very small or non-detectable amounts, and even decreased the content of some saturated fatty acids, probably due to very severe oxidation conditions (Huang et al., 2014). The sensitivity of polyunsaturated fatty acids to oxidation was also shown in the ozonation of $D$. salina where accumulation of saturated fatty acids and even some hydrocarbons were detected in the extracted lipids (Kamaroddin et al., 2016).

The reduction in chlorophyll content is considered beneficial when the isolated lipids are transformed into biodiesel as chlorophyll deactivates the esterification catalyst (Seo et al., 2015a). Equally beneficial is the reduction in polyunsaturated fatty acids and the increase in saturated, as the corresponding saturated fatty acid methyl esters (biodiesel) are more resistant to oxidation and degradation from oxygen, heat, light etc. (Concas et al., 2015a; Steriti et al., 2014). However, if the targeted products are high added value molecules such as unsaturated fatty acids (e.g. $\omega 3$ fatty acids) pigments (e.g. chlorophyll, carotenoids) and antioxidants (e.g. astaxanthin) that are sensitive to oxidation, such pretreatment methods may be detrimental to the product quality and/or yield. If optimization of oxidative processes to minimize product degradation is not possible, they should be exclusively used for the 
production of bulk products such as fermentable sugars (Keris-Sen and Gurol, 2017), biogas(Martín Juárez et al., 2018) and biodiesel (Steriti et al., 2014).

\subsection{Enzymatic methods}

Enzymatic treatment is even more species specific than the methods described above. Microalgal cell walls are chemically complex and may contain several carbohydrates (cellulose, hemicellulose, pectin or chitin), protein or other organic polymers such as sporopollenin and algaenan. They are also structurally complex as these polymers are often organized in layers. Cell wall structure and composition varies between species and as a result the enzymatic activities on cell walls of different species will differ. Successful enzymatic disruption of such complex structures requires combinations of the necessary enzymatic activities. Indeed, the treatment of $N$. gaditana with Alkalase -a protease with esterase activity for peptide and amino acid esters- showed only 35\% protein release (Safi et al., 2017b). Although significant hydrolysis of protein can be achieved, cell wall integrity was not compromised and cell breakage was not detected, because the remaining structural components remain intact. Another disadvantage of the protease is the reduction of the released protein functionality due to their hydrolytic fragmentation (Safi et al., 2017a).

Similarly, treatment of Scenedesmus sp. with lysozyme -an enzyme that hydrolyses cell wall peptidoglycan by specifically degrading $\mathrm{N}$-acetylglucosamine- increased the lipid extraction yield by only $16.6 \%$ compared with cellulase treatment alone (Taher et al., 2014). Lysozyme treatment on $C$. vulgaris thinned and delaminated the outer wall and removed hair-like fibers from the cell's surface (Gerken et al., 2013). This study compared many enzymes (chitinase, chitosanase, b-glucuronidase, pectolyase, trypsin, laminarinase, lyticase, phospholipase A1, sulfatase, b-glucuronidase and sulfatase) and showed that lysozyme was the only enzyme able to increase cell permeability when applied alone. When lysozyme and sulfatase were combined the permeabilization of $96 \%$ of the cell population was achieved. In other experiments lysozyme treatment, enabled high protein and pigments extraction from Chlorella sp., Scenedesmus sp. and Chlamydomonas sp. (Al-Zuhair et al., 2017). This required a 30fold increase in the pretreatment time (16h) compared to the previous study (Taher et al., 2014).

The combination of a protease with a cellulase is a typical enzymatic treatment strategy as it can target the two main cell wall components, proteins/peptides and cellulose and/or other carbohydrates. In the treatment of $C$. reinhardtii and $C$. vulgaris Alkalase and Viscozyme (a multienzyme with b-glucanase, arabinase, hemicellulase, xylanase and other activities) led to almost complete protein and carbohydrate solubilization (Mahdy et al., 2014b). Cellulase, pectinase and lysozyme were used together for lipid extraction from Nannochloropsis sp. with a $22 \%$ recovery yield (Chen et al., 2017). In some cases, the cellulase-protease combination performed poorly. For example, treatment of $H$. pluvialis by combined protease $\mathrm{K}$ and drierase (a cellulase, hemicellulase and pectinase mix) did not enhance the extraction efficiency of astaxanthin. This was attributed to the enzymes inability to attack the cell wall sporopollenin, a very recalcitrant polymer (Mendes-Pinto et al., 2001). This underlines the importance of selecting the appropriate mix of enzymatic activities according to the microalgae specie.

Combination of carbohydrate hydrolyzing enzymes is another strategy for cell wall disruption. The combined use of cellulase and pectinase at 1:1 ratio and $7000 \mathrm{U} \mathrm{mL}^{-1}$ total enzyme dosage enabled $71 \%$ astaxanthin extraction (Ye et al., 2020). The combined treatment of Nannochloropsis sp. with Cellulyve ${ }^{\circledR}$ 50LC (cellulase) and Feedlyve ${ }^{\circledR}$ GMA (Endo- $\beta$-1,4-mannanase) led to a lipid extraction yield of $90 \%$ (Zuorro et al., 2016). Treatment with carbohydrase cocktails has also been performed in tandem, when the enzymes have different temperature optima simultaneous treatment would lead to denaturation and loss of some enzymatic activity. For example, treatment of mixed cultures with $\beta$ glucosidase/cellulase at $65^{\circ} \mathrm{C}$, followed by $\alpha$-amylase at $95^{\circ} \mathrm{C}$ and an amyloglucosidase at $55^{\circ} \mathrm{C}$ yielded $95 \%$ of total sugars (Shokrkar et al., 2017). A similar total sugar yield of $92 \%$ was achieved by the same treatment strategy in the case of $H$. tetrachotoma ME03 (Onay, 2019). Fermentation of the sugar hydrolysates gave approximately $90 \%$ of theoretical bioethanol yield. It is also worth noting that the enzymatic reaction sequence initially targeted the cell wall structural carbohydrates (cellulase and b- 
glucosidase activities) followed by the intracellular storage carbohydrates (a-amylase and amyloglucosidase activities). This enzyme specificity towards the targeted molecules could be useful in hydrolysis products separation e.g. carbohydrates and proteins. This can be achieved by sequential treatment, first with proteases to enable protein release, followed by carbohydrate hydrolysing enzymes to remove sugars from the microalgae biomass.

A variation of enzymatic pretreatment is autolysis. It occurs when the microalgae cells under stress produce cell wall degrading enzymes leading to cell lysis. When $C$. reinhardtii is exposed to nitrogen depletion stress the production of autolysin is induced. Autolysin is a protease that targets proline-rich areas in $C$. reinhardtii cell wall polypeptides. Its synthesis can be enough to enable extensive cell disruption and quantitative protein and lipid release (Sierra et al., 2017). The main benefits of this strategy are the expensive enzyme redundancy and conservation of intracellular protein integrity. Another strategy to reduce the high cost of enzymes is their in-situ production by coculturing the microalgae with an enzyme producing microorganism. For this reason, $C$. vulgaris was co-cultured with the bacterium Flammeovirga yaeyamensis that could release amylase, cellulase, and xylanase in the growth medium (Chen et al., 2013). The collected microalgae cells showed damage to the cell walls induced from the enzymes during co-culture. The supernatant from the co-culture was used to pretreat C. vulgaris cells in a separate pretreatment process, significantly increasing the release of hydrolyzed sugars and lipids.

The non-specific enzymatic pretreatment of microalgae is also possible with the use of oxidizing enzymes. For example, manganese peroxidase (a lignin degrading enzyme using $\mathrm{Mn}^{2+}$ ions as oxidizing mediators) was produced by the white-rot fungi Anthracophyllum discolor. The enzymatic extract was used for the pretreatment of Botryococcus braunii to enhance methane production (Ciudad et al., 2014). The enzymatic pretreatment increased methane production from approximately $320 \mathrm{~mL} \mathrm{CH}_{4} / \mathrm{g}$ VS to $521 \mathrm{~mL} \mathrm{CH}_{4} / \mathrm{g}$ VS that corresponds to $90 \%$ of biodegradability, compared to $60 \%$ biodegradability of the untreated microalgae cells. A complex enzymatic broth containing laccase (another lignin oxidizing enzyme) from the fungus Trametes versicolor exhibited similar improvement in methane production from the anaerobic digestion of pre-treated mixed microalgae cultures (Hom-Diaz et al., 2016).

Despite the promising results, high enzyme cost is the major hurdle to be overcome for application of enzymatic processes to biorefineries. Several strategies have been employed towards this end, such as co-cultivation and autolysis that were discussed above. Another strategy concerns the optimization of the enzyme production process to reduce production cost through increased productivity and yield. Reduction of cost through lowering the enzyme dosage has also been achieved by optimizing the enzymatic cocktail and by discovery of new more potent enzymes. Such approaches in bioethanol production from lignocellulosic biomass have reduced the enzyme production costs by a factor of ten (10) (Dahiya, 2020).

Table 9

\subsection{Novel downstream processing concepts}

\subsubsection{Combinations of cell disruption methods}

Combinations of disruption methods have been frequently investigated to increase pretreatment efficiency. One example is the combination of heat treatment together with High Pressure Homogenization. This led to an initial increase in viscosity due to increased solubilization of polymers, such as proteins and carbohydrates, and a subsequent reduction of viscosity from the HPH treatment caused by a decrease in the molecular weight due to increased shear thinning (Bernaerts et al., 2018, 2017). The combination allowed the treatment of cells at high concentrations, e.g. Nannochloropsis sp pastes of $20-25 \%$ solids (Olmstead et al., 2013). The thermal pretreatment increased cell wall susceptibility to mechanical disruption by HPH and improved lipid extraction yields (Halim et al., 2016).

Ultrasonication is a pretreatment method with moderate efficiency, however, it can be easily combined with other methods to increase cell disruption capability. When used together with $\mathrm{H}_{2} \mathrm{O}_{2}$ oxidation a 
two-fold increase of $C$. pyrenoidosa cell lysis was achieved, compare to ultrasonication alone (Z. Duan et al., 2017). Combined with alkali pretreatment it could improve cell disruption, protein solubilization and protein yield from $C$. sorokiniana and $C$. vulgaris, compared to either pretreatment method on its own (Phong et al., 2018). Improved cell lysis was also observed when ultrasonication was combined with physical pretreatment methods such as pressure drop through nozzle spraying (M. Wang and Yuan, 2015). When Parachlorella kessleri was treated with HPH low protein and carbohydrate yields of $11 \%$ and $20 \%$, were obtained, respectively. When HPH was preceded by ultrasonication these values increased to $89 \%$ and $74 \%$, respectively (Zhang et al., 2019a). Ultrasonication in combination with a two-phase system of methanol/ $\mathrm{K}_{3} \mathrm{PO}_{4}$ solution can effectively combine cell-lysis and partition of proteins from cellular debris in one step (Phong et al., 2017). Cell lysis and recovery of protein in a single step is also possible with the combination of ultrasonication in an ionic liquid, that led to $95.0 \%$ protein recovery (Sze Ying Lee et al., 2017). Despite these interesting concepts, the major drawback of ultrasonication remains its inability to process high cell concentration cell-pastes. Ultrasolication at 400 $\mathrm{W}$ has been used in combination with the ionic liquid cholinium 2-hydroxy-3morpholinopropanesulfonate to extract $95 \%$ of total protein from $C$. vulgaris cells. Cell disruption and protein extraction were performed in a single step as the ionic liquid (as a $50 \mathrm{mM}$ aqueous buffer) was a suitable solvent for protein extraction (Lee et al., 2017). The processing time was $30 \mathrm{~min}$ and biomass concentration was $6 \mathrm{~g} \mathrm{~L}^{-1}$ (Lee et al., 2017).

\subsubsection{Novel cell disruption methods}

\subsubsection{1. $\mathrm{CO}_{2}$ explosion}

Cell lysis via $\mathrm{CO}_{2}$ explosion is an interesting method for microalgae pretreatment. The method includes cell pressurization with $\mathrm{CO}_{2}$ that leads to increased intracellular gas concentration. It is followed by the rapid pressure release that causes expansion of intracellular gas and leads to cell disruption. It has already been shown to work for lipid extraction from the lipid producing yeast Rhodotorula glutinis, where $\mathrm{CO}_{2}$ explosion was performed at 35 bar, leading to significant cell breakage and release of intracellular lipids to the aqueous phase (Howlader et al., 2017). The method has also been used for the extraction of carotenoids and chlorophylls from B. braunii (Uquiche et al., 2016). Pretreatment at $21^{\circ} \mathrm{C}$ and 130 bar increased the pigments extraction yield 10-fold compared with non-treated cells. $\mathrm{CO}_{2}$ explosion is similar to steam explosion, but the lack of heating reduces degradation reactions and could be a viable method for the extraction of valuable and sensitive intracellular molecules. Lately, a continuous $\mathrm{CO}_{2}$ explosion system was described that can effectively disrupt Neochloris oleoabundans UTEX 1185 cells. The continuous method reduced $\mathrm{CO}_{2}$ consumption between 2-4 fold, reduced the process time 3-9 fold, and increased biomolecule yields by more than 2 fold compared to the batch method (Günerken et al., 2019). Other non-reactive gasses such as $\mathrm{N}_{2}$ can also be used for cell lysis through explosive decompression (Simpson, 2010).

\subsubsection{Electricity-based methods}

High voltage electric discharges (HVED) utilizes electrodes of needle-plate geometry to deliver high voltage pulses to microalgae suspensions. Electroporation of cells similar to that hown for PEF is also present in HVED treatment. HVED additionally induces thermal and mechanical effects to the cells due to cavitation and shockwave formation (Zhang et al., 2019c). Application of HVED (40 kV cm$\left.{ }^{-1}, 4 \mathrm{~ms}\right)$ to Nannochloropsis sp. allowed the selective release of ionic components and small molecular weight water soluble components. Aggregation of the cells as a result of the electric discharge was also observed (Grimi et al., 2014). These findings were also confirmed in the HVED treatment of $1 \% \mathrm{w} / \mathrm{w}$ Parachlorella kessleri suspensions at similar conditions $\left(40 \mathrm{kV} \mathrm{cm}^{-1}, 8 \mathrm{~ms}\right)$ that led to release of ionic cell components and carbohydrates but protein yield was only $15 \%$ w/w (Zhang et al., 2019b). For this reason, HVED was proposed as a first treatment step for the selective release of low molecular weight 
and water-soluble molecules, followed by organic solvent extraction of chlorophylls, carotenoids and lipids (Zhang et al., 2020). Application of HVED to B. braunii cell collonies allows the easy separation of the cells from their hydrocarbon extracellular matrix. Subsequantly cells sink to the bottom while the hydrocarbon matrix rises to the surface of the process vessel, allowing for easy separation and collection (Guionet et al., 2019).

Non-thermal plasma is another electricity-based method where a needle to plate electrode geometry is placed in an argon filled reactor. The application of high voltage $(17 \mathrm{kV}, 30 \mathrm{~mA})$ between the electrodes generated an intense core plasma towards the microalgae biomas that led to 65-70\% cell rupture of $N$. gaditana cells and $18.7 \%$ lipid extraction (Matos et al., 2019). The method decreased the content of polyunsaturated $\omega-3$ fatty acids from $31 \%$ to $11 \%$ making it more suitable to biofuels applications. Nanowire-assisted electroporation of Chlorella sp. with copper oxide nanowire-modified threedimensional copper foam electrodes $(10 \mathrm{sec}, 2 \mathrm{~V})$ led to complete inactivation and disruption of the cells and release of organic matter in the liquid phase $\left(50 \mathrm{mg} \mathrm{L}^{-1}\right)$ with a very low energy consumption 0.014 $\mathrm{kWh} \mathrm{kg}^{-1}$ (Bai et al., 2019). Osmotic shock of A. platensis at the same pretreatment conditions led to the highest lipid yield (8.9\% extracted with chloroform/methanol 1:2 v/v) compared to ultrasonication, autoclave, acid and alkaline treatments (Sumprasit et al., 2017)

\subsubsection{Osmotic shock}

Osmotic shock is a simple and effective microalgae pretreatment method. When microalgae cells are suspended in high concentration salt solutions, the density difference between cytoplasm and salt solution creates an osmotic pressure across the cellular membrane that can lead to cell disruption. Treatment of C. vulgaris cells in a $10 \% \mathrm{w} / \mathrm{v} \mathrm{NaCl}$ solution for $48 \mathrm{~h}$ yielded $86 \%$ of total lipids. Microscopic observations showed that osmotic shock acts by creating holes in the cell membranes and does not lead to complete cell disintegration. The disruption effect treatment is also more homogeneous in the cell population (Heo et al., 2017). Effectiveness of the osmotic shock treatment depends on the concentration of the salt solution. When $6 \% \mathrm{w} / \mathrm{v}$ solutions of $\mathrm{NaCl}$ and sorbitol were used for the pretreatment of $C$. reinhardtii, lipid yields were not increased compared to the untreated cells (Yoo et al., 2012). When cell wall-free mutants were treated at the same conditions, lipid yield for sorbitol and $\mathrm{NaCl}$ increased to $20 \%$ and 35\%, respectively (Yoo et al., 2012). The type and concentration of salts, incubation time and concentration of biomass are all important factors affecting the efficiency of the method (Krishna Koyande et al., 2020). Osmotic shock has been used for extraction of protein from $C$. vulgaris biomass. Treatment with magnesium sulphate at $100 \mathrm{~g} \mathrm{~L}^{-1}$ for $10 \mathrm{~min}$ resulted in a high (> 90\%) protein recovery. Increasing the biomass concentration from $0.25 \% \mathrm{w} / \mathrm{w}$ to $5 \% \mathrm{w} / \mathrm{w}$ resulted in a slight decrease of protein yield to approximately $80 \%$ (Krishna Koyande et al., 2020). Osmotic shock is an attractive cell disruption method due to its simplicity and promising yields in biomolecules extraction. Although prohibitively high treatment times of $48 \mathrm{~h}$ are often reported, low treatment times of $10 \mathrm{~min}$ ware also shown, indicating that optimization of the method can reduce treatment time to more realistic levels.

\subsubsection{Ionic liquids}

Ionic liquids are organic salts with low melting points below $100{ }^{\circ} \mathrm{C}$. The cation contains heteroatoms in the organic structure, usually nitrogen. The cations can be imidazolium, pyridinium, ammonium, cholinium and phosphonium, among others (Orr et al., 2016). The anions can be either organic or inorganic. Many ionic liquids are found in liquid form at room temperature and are very stable chemically and thermally. (Nitsos et al., 2013). These useful properties have classified them as green solvents. Ionic liquids have the ability to form hydrogen bonds, which allows them to interact with biopolymers such as cellulose found in the cell wall of microalgae. The recalcitrance of cellulose is based on the large number of hydrogen bonds formed between the cellulose microfibrils. The hydrogen bond capacity of ionic liquids allows the disruption of these interfibrillar hydrogen bonds of cellulose and can dissolve the cellulose structure. This leads to compromised microalgae cell wall structures and 
allows the more efficient extraction of intracellular or cell wall components of the microalgae (Chen et al., 2018). The chemical hydrolysis of cellulose by ionic liquids has also been proposed (van Spronsen et al., 2011). Interaction with other cell wall components like hemicelluloses and proteins is also possible, although the complexity of the cell wall composition and variation between species make the exact mechanism of action still unclear (Orr et al., 2016).

Imidazolium based ionic liquids are very commonly used for microalgae pretreatment and are very effective at improving lipid extraction (Orr et al., 2016). For example, pretreatment of $C$. vulgaris with different types of imidazolium based ionic liquids (Table 10) led to complete cell lysis and extraction yields ranging from 45 to $98 \%$ of total lipids (Teixeira, 2012). However, employment of high temperature $\left(140^{\circ} \mathrm{C}\right)$ for $30 \mathrm{~min}$ increases the energy input of the method. The requirement of heating to relatively elevated temperatures is relatively common in ionic liquid treatments, which could potentially render them less energy efficient (Orr et al., 2016). For this reason, microalgae treatment with ionic liquids at room temperatures has attracted some attention. Disruption of $C$. vulgaris cells was achieved with a variety of ionic liquids at ambient temperature for $16 \mathrm{~h}$. Extraction of lipids from the pretreated cells with hexane showed significant improvement compared to untreated biomass ( $5 \% \mathrm{~g} \mathrm{~g}^{-1}$ biomass lipid extraction yield). The best result $\left(25 \% \mathrm{~g} \mathrm{~g}^{-1}\right.$ biomass lipid extraction) was shown for a phosphonium ionic liquid tributylmethylphosphonium propanoate (Orr et al., 2016). These results however were performed with freeze dried biomass, that can facilitate the easier extraction of lipids due to structural damage to the cell membranes. Depending on pretreatment conditions, milder effects of ionic liquids on the lipid extraction yields from wet microalgal biomass (20\%-40\% of total oils) compared to freeze dried biomass (80-90\% of total oils) have been observed (Zhang et al., 2018). In the same study optimization of the pretreatment and extraction process using the phosphonium salt tributylmethylphosphonium propanoate could increase the oil yield at $80 \%$ (Zhang et al., 2018). The use of butyrolactam, caprolactam, propylammonium and hydroxypropylammonium based ionic liquids in the treatment of wet Chlorella sp. and Chlorococcum sp. achieved very good cell disruption. The best results were demonstrated by butyrolactam hexanoate with efficiency of $76 \%$ and $84 \%$ for Chlorella $s p$. and Chlorococcum sp., respectively (Shankar et al., 2017). These results were obtained at room temperature, but long treatment times of 24 hours were required. Pigment extraction has also been reported with ionic liquids. Extraction of $85 \%$ of total astaxanthin was achieved with the treatment of H. pluvialis with a $40 \% \mathrm{w} / \mathrm{w}$ aqueous solution of 1-Butyl-3-Methylimidazolium Chloride for $1 \mathrm{~h}$ at 60 ${ }^{\circ} \mathrm{C}$. Astaxanthin was extracted with methanol (Liu et al., 2018).

Table 10.

\subsubsection{Viral cell lysis}

A very novel approach, appealing for its low energy requirement is the viral lysis of microalgae cell walls. For example, infection of Chlorella variabilis by the Chlorella-virus Paramecium bursaria led to almost complete cell lysis and lipid yields comparable to microwave and ultrasonication (Kim and Kim, 2018). The method also proved successful in the production of bioethanol from starchaccumulating $C$. variabilis when combined with amylase treatment of the released starch and fermentation (Cheng et al., 2013). Viral production and cell lysis efficiency was significantly influenced by the carbon to nitrogen ratio of the culture when viral infection was done in situ (Y.-S. Cheng et al., 2015). This approach allows for nitrogen content manipulation to optimize lipid or carbohydrate production and hence, cell lysis. Additionally, it reduces the processing times of viral cell lysis (Kim and Kim, 2018).

\subsubsection{Cell disruption by contact}

Cell disruption of Aurantiochytrium sp. was achieved with a poly-dimethylaminomethylstyrene coated nylon membrane. The membrane was submerged in a culture of microalgale cells and the culture was shaken bringing the membrane and cells into contact. Contact of the negatively charged cell surface with 
the functionalized membrane's positive charged surface led to electrostatic interactions -possibly rearrangements in the phospholipid bilayer- and cell lysis. Although cell disruption efficiency was relatively low (26\%) the method is very promising due to its simplicity and low energy requirements. (Yoo et al., 2013).

A similar effect was noticed when C. vulgaris cells were contacted with silver nanoparticles (Abdul Razack et al., 2016). Silver nanoparticles are known for their bacteriocidal properties that are promoted by a positive surface charge (Abbaszadegan et al., 2015), and therefore a similar cell lysis mechanism may be in action. The proposed method, however, included drying of the cells both pre and post treatment and its efficiency on wet microalgae could vary.

\subsubsection{Combined harvesting and cell disruption}

Among the most promising novel approaches are those combining harvesting with microalgae biomass pretreatment. Such methods if properly optimized can have significant benefits for both capital investment and operating costs as they reduce the number of downstream unit operations required. One such example is electroflotation, by alternating current (Florentino de Souza Silva et al., 2014). Introduction of the alternating current that breaks water molecules and creates oxidative species like $\mathrm{O}_{3}$, $\mathrm{H}_{2} \mathrm{O}_{2}$ and $-\mathrm{OH}$. These in turn cause cell disruption through oxidative reactions. The method achieved very high harvesting efficiency of $99 \%$ at 140 min processing time. Lipid extraction yield with chloroform-methanol increased from 5\% in untreated cells to $25 \%$ when pretreated with electroflotation. In a similar approach ozonoflotation, combines the harvesting effect of gas bubbles with the oxidative pretreatment induced by the contact of ozone with the microalgae cell walls. The method could harvest $80 \%$ of the algal biomass and double the lipids yield (measured by extraction with chloroform-methanol $2: 1 \mathrm{v} / \mathrm{v}$ from lyophilized biomass), indicating significant cell disruption effects (Velasquez-Orta et al., 2014). Ozonation could potentially achieve the simultaneous disinfection, harvesting and pretreatment of cultures as was demonstrated by the short time in situ ozonation of D. salina (Kamaroddin et al., 2016). The study showed that ozonation of a mixed culture of the green alga D. salina and Halomonas, a Gram-negative bacterium representing bacterial contamination, with $8 \mathrm{mg} \mathrm{L}^{-1}$ of ozone for $10 \mathrm{~min}$ resulted 93\% sterilization efficiency without harming the microalgae cells (Kamaroddin et al., 2016). Ozone-flotation has been used for efficient harvesting and pretreatment of microalgae for biooil production through hydrothermal liquefaction (Nava Bravo et al., 2019). One of the major disadvantages of open pond systems is the high contamination from bacteria and other microorganisms as they are exposed to the natural elements. This problem can be enhanced when process water -that often carries a high bacterial load- is used as the culture medium. Reduction of bacterial load during cultivation or during harvesting and pretreatment with ozonation can make open pond systems more attractive for microalgae biorefineries.

Combined harvesting and pretreatment can also be achieved by a flocculation variation. Cells are harvested by coagulation-flocculation with ferric chloride at $200 \mathrm{ppm}$ and $\mathrm{pH} 3$ with $90 \%$ efficiency after $20 \mathrm{~min}$. In the second step, cells are pretreated with $0.5 \% \mathrm{H}_{2} \mathrm{O}_{2}$ at $90{ }^{\circ} \mathrm{C}$. Interaction of ferric ions with $\mathrm{H}_{2} \mathrm{O}_{2}$ forms a Fenton-like reagent with potent oxidation radicals leading to $80 \%$ lipid extraction efficiency. With oxidized pyrite $(20 \mathrm{mM})$ as catalyst, $90 \%$ lipid extraction and esterification were achieved (Seo et al., 2015b). As has been described in the oxidative pretreatment section, such methods may not be suitable for the valorization of antioxidants, pigments, and unsaturated fatty acids due to the severe influence of the oxidative reagents.

\subsection{Energy efficiency of downstream processing}

Among the reviewed microalgae harvesting methods, dissolved air flotation (Niaghi et al., 2015) and electroflocculation (Vandamme et al., 2011) appear to be the most energy efficient with $0.0025 \mathrm{kWh} \mathrm{m}^{-}$ ${ }^{3}$ and $0.15-1 \mathrm{kWh} \mathrm{m}^{-3}$ of sample, respectively. However, as these harvesting methods were performed at 
the laboratory scale, upscaling could alter the energy requirements of the processes. Centrifugation also shows a favorable energetic assessment with an energy range of $0.70-1.30 \mathrm{kWh} \mathrm{m}^{-3}$ required at high scale (Fasaei et al., 2018). The main advantage of centrifugation systems is their ability to deliver high harvesting efficiency (up to 99\%) and high solids concentrations (up to 20\%) at this energy range (Table 11). This makes centrifugation ideal as a dewatering process able to produce microalgae pastes. Its combination with other harvesting techniques therefore could establish efficient harvesting and dewatering operations (Fasaei et al., 2018). A scenario of combined membrane filtration and centrifugation for harvesting and dewatering required $0.84 \mathrm{kWh} \cdot \mathrm{kg}^{-1}$, which is inside the energy input range of centrifugation alone (Table 11). Flocculation combined with centrifugation in the same scenario considerably reduced the energy requirements to $0.06 \mathrm{kWh} \cdot \mathrm{kg}^{-1}$ (Fasaei et al., 2018). A similar energy input $\left(0.05 \mathrm{kWh} \cdot \mathrm{kg}^{-1}\right)$ was required for combined flocculation and membrane filtration. From these examples it is apparent that size increase induced through the formation of flocks greatly enhances the efficiency of both centrifugation and membrane filtration. On the other hand, the use of flocculants increases the cost to $0.97 € \mathrm{Kg}^{-1}$ compared to the $0.30 € \mathrm{Kg}^{-1}$ required for combined membrane filtration and centrifugation. Such scenarios provide good benchmarks for development of harvesting and dewatering systems tailored to the needs of specific microalgae biorefineries. Selection of the appropriate methods could depend on the application, for example value of isolated biomolecules and the energy content of the biomass for biofuel production.

The energy efficiency of High Pressure Homogenization cell disruption method has been extensively studied. Energy consumption is dependent on biomass concentration. Low cell densities clearly do not favor the treatment in terms of energy requirements. For example, $20 \mathrm{kWh} \mathrm{kg}^{-1} \mathrm{DW}$ is required for cell disintegration of $1.2 \%$, w/w C. vulgaris suspensions (Carullo et al., 2018). Increasing the concentration of Desmodesmus sp. F51413 from $2.0 \mathrm{~g} \mathrm{~L}^{-1}$ to $90 \mathrm{~g} \mathrm{~L}^{-1}$ reduced the specific energy consumption from $413 \mathrm{~kJ} \mathrm{~g}^{-1}$ to $9.19 \mathrm{~kJ} \mathrm{~g}^{-1}$ (Xie et al., 2016). This solids content increase does not affect carotenoid extraction yields that remains unchanged throughout the whole $2.0 \mathrm{~g} \mathrm{~L}^{-1}$ to $90 \mathrm{~g} \mathrm{~L}^{-1}$ range. Efficient disruption ( $>95 \%)$ of a $10 \%$ suspension of $N$. gaditana could also be achieved at high energy efficiency $\left(<0.5 \mathrm{kWh} \mathrm{kg}^{-1}\right.$ biomass). The method is also cost efficient with a reported price range of $0.15-0.25 €$ $\mathrm{kg}^{-1}$ of isolated protein (Safi et al., 2017a). Energy requirements are also dependent on cell wall robustness. The energy required for the disruption of single of $T$. suecica cells was $5.88 \times 10^{-5} \mathrm{~J}_{\text {cell }}{ }^{; 1}$ for Chlorococcum sp., it was $6.4310^{-5} \mathrm{~J} \mathrm{cell}^{-1}$ (Halim et al., 2013). The cell walls of T. suecica are made up from polysaccharides such as mannans, together with 2-keto sugars and glycoproteins. Chlorococcum $s p$. has a cell wall primarily of polysaccharides such as cellulose pectins, hydroxyprolinerich glycoproteins and arabinogalactan proteins. Correlation of cell wall strength to compositional differences are not easy. However, the authors have attributed the difference in energy disruption requirements to the thinner cell walls of $T$. suecica. For relatively fragile microalgae like Nannochloropsis sp. cell disruption and energy efficiency were independent of cell density up to $25 \%$ solids (Yap et al., 2015); although this effect could be related with the ease of cell wall disruption it remains to be investigated. Treatment of the relatively tough $B$. braunii was also energy efficient $(\sim 0.04$ $\mathrm{kWh} \mathrm{kg}^{-1}$ ) when extraction of the hydrocarbon rich extracellular matrix was considered (Tsutsumi et al., 2017).

Bead milling was less energy efficient compared to HPH for the disruption of $N$. gaditana cells for maximum protein release $\left(0.43 \mathrm{kWh} \mathrm{kg}^{-1}\right.$ and $0.32 \mathrm{kWh} \mathrm{kg}^{-1}$, respectively) (Safi et al., 2017a). Specific energy requirements were, reported for maximum protein release by bead milling from $T$. suecica $(0.49$ $\left.\mathrm{kWh} \mathrm{kg}^{-1}\right)$, Neochloris oleoabundans $\left(0.55 \mathrm{kWh} \mathrm{kg}^{-1}\right)$ and C. vulgaris $\left(0.72 \mathrm{kWh} \mathrm{kg}^{-1}\right)$, with experiments performed at $9 \%(\mathrm{w} / \mathrm{v})$ solids (Postma et al., 2017). It was also shown that energy efficiency can increase with the reduction of bead diameter, probably due to more efficient bead impacting. Maximum carbohydrate release was achieved at similar specific energy for $T$. suecica $\left(0.48 \mathrm{kWh} \mathrm{kg}^{-1}\right)$ and $C$. vulgaris $\left(0.72 \mathrm{kWh} \mathrm{kg}^{-1}\right)$ but higher energy input was required for $N$. oleoabundans $\left(0.94 \mathrm{kWh} \mathrm{kg}^{-1}\right)$. These values indicate that both HPH and bead milling can perform below the maximum specific energy limit of $0.682 \mathrm{kWh} \mathrm{kg}^{-1}$ for efficient target molecules extraction in the biorefinery, as set by the National Algal Biofuels Technology Roadmap target of the US Department of Energy (Postma et al., 2017). Bead milling treatment of B. braunii is also energy efficient $\left(\sim 0.08 \mathrm{kWh} \mathrm{kg}^{-1}\right)$. 
PEF pretreatment of $10 \%$ solids of $N$. gaditana cells was significantly less efficient compared to HPH and bead milling requiring an energy input of $10.42 \mathrm{kWh} \cdot \mathrm{kg}^{-1}$ for a very low $10 \%$ protein yield, compared to 50\% with the other methods at much lower energy inputs (Safi et al., 2017a). The very small size of $N$. gaditana cells $(2-4 \mu \mathrm{m})$ could adversely affect PEF efficiency and PEF should be only considered for larger microalgae cells. Protein extraction from $C$. reinhardtii by PEF pretreatment was equally inefficient in terms of energy input. Even at high energy input of $26.5 \mathrm{kWh} \mathrm{kg}^{-1}$ protein yields did not exceed 15\% (T Lam et al., 2017). The average cell size of $C$. reinhardtii was 4-5 $\mu \mathrm{m}$. In contrast disruption of the cell wall deficient mutant of $C$. reinhardtii, in the same study, was more energy efficient with $40 \%$ protein yield at $2.5 \mathrm{kWh} \mathrm{kg}^{-1}$ (T Lam et al., 2017). This shows that the cell wall of $C$. reinhardtii causes its resilience to PEF and indicates that PEF may be less suitable for microalgae species with a recalcitrant cell wall. Even at low biomass concentrations $\left(4 \mathrm{~g} \mathrm{~L}^{-1}\right) \mathrm{PEF}$ is still not as energy efficient as $\mathrm{HPH}$ and bead milling. Contradicting these results efficient extraction of molecules from $A$. protothecoides with PEF at $10 \%$ solids was reported with a $0.42 \mathrm{kWh} \mathrm{kg}^{-1}$ specific energy input (Eing et al., 2013). Average cell size was larger at $7 \mu \mathrm{m}$ and the studied microalgae is known to have a rigid cell wall consisting of a triple layer with an acetolysis-resistant material sandwiched between polysaccharides (Kalina et al., 1993). These discrepancies demonstrate how careful optimization may be needed for a more conclusive evaluation of a process potential, and that process efficiency can be species specific.

Hydrothermal treatment methods also appear to be energy efficient. An $87 \%$ disruption of $N$. oculata cells could be achieved with water bath heating at $0.01 \mathrm{kWh} \mathrm{L}^{-1}$ energy input (McMillan et al., 2013). Steam explosion of $C$. sorokiniana was very efficient as it enabled microalgal biomass solubilization in the range $65-73 \%$ with an energy input of $0.03-0.06 \mathrm{kWh} \mathrm{kg}^{-1}$ of volatile solids (Córdova et al., 2018). These studies, however, lacked information on solids content of the treated sample and therefore the more relevant specific energy input per unit biomass could be significantly higher. An energy input of $1.58 \mathrm{kWh} \mathrm{kg}^{-1}$ for the autoclaving of $S$. obliquus $\left(5 \mathrm{~min}\right.$ at $\left.121{ }^{\circ} \mathrm{C}\right)$ is a more accurate estimation of the energy requirements of hydrothermal treatment (Ansari et al., 2018). Even at these relatively mild pretreatment conditions five-fold higher energy is required compared to HPH and bead milling. Even higher energy input $\left(2.26 \mathrm{kWh} \mathrm{kg}^{-1}\right)$ was reported for the efficient disruption of Nannochloropsis oceanica at $10 \%$ solids by steam explosion. At these optimal pretreatment conditions extensive cell disruption and almost complete lipid recovery could be achieved (J. Cheng et al., 2015). Although the energy input is higher compared with previously discussed HPH and bead milling significant heat recovery is possible for hydrothermal and steam explosion pretreatment methods via heat exchange (Chen et al., 2019b).

Utrasound and osmotic shock treatments were in the same energy range as hydrothermal with $1.5 \mathrm{kWh}$ $\mathrm{kg}^{-1}$ and $1.72 \mathrm{kWh} \mathrm{kg}^{-1}$, respectively (Ansari et al., 2018). Enzymatic treatments are also very attractive and promising methods due to their low energy requirements. The treatment of a $10 \%(\mathrm{w} / \mathrm{v})$ slurry of $N$. gaditana with Alkalase could be performed at a specific energy input of $0.34 \mathrm{kWh} \mathrm{kg}^{-1}$ (Safi et al., 2017a). Although soluble protein yield was lower compared to HPH and bead milling in the same study, enzymatic reaction optimization and use of complementary enzymatic activities can greatly improve the reaction efficiency, as was previously discussed.

\section{Table 11}

Table 12

\section{Conclusion and outlook}

Although a significant amount of research on microalgae valorization has been conducted it cannot be considered exhaustive. The large number of available (as well as yet unexplored) microalgae species combined with the variety of downstream processing methods requires an even greater research and optimisation effort. A unification and standardization of reporting would allow the easier comparison of 
different studies and a more comprehensive understanding of the field. For example, the microalgae cell concentration in slurries is reported in various ways including number of cells per unit of volume, volatile solids per unit of volume and total solids per unit of volume, often hampering comparison of reported results between studies. Similarly, the pretreatment method efficiency has been variably evaluated by cell lysis, turbidity and product extraction yield. Between these methods cell counting is an objective way of reporting cell disruption efficiency. Turbidity is affected by cell size and agglomeration of cells or debris, and yield can be affected by the formation of degradation products (Spiden et al., 2013). Decrease of the cells dry weight (due to release of intracellular materials) and increase of free proteins and DNA in the supernatant are good indicators that the cell wall structure is compromised. These methods could be sufficient to express pretreatment efficiency, especially as partial cell wall disruption is not visible by cell counting (Safi et al., 2017a).

Energy efficiency is reported as energy input per unit of microalgal biomass, energy input per unit of harvested product, energy input per unit energy content of the microalgal biomass or its lipid products. The latter calculation methods are more important when biofuels and energy are the main microalgal biorefinery target products, as the overall process net energy ratio cannot exceed the energy content of the microalgae and its products. When the production of high value molecules such as antioxidants, pigments, and food supplements is the main goal of the biorefinery energy input is more related to process cost and therefore should be reported as energy input per unit mass of the biomass.

The effect of biomass concentration on the energy and the extraction efficiency of the various pretreatment methods, has not been thoroughly investigated yet. Few methods have demonstrated efficient cell disruption at truly high biomass concentrations such as $20 \%$. Much of the works were conducted at cell concentrations around or below 10\%. Indeed, it appears that $10 \%$ solids content represents a limit above which mixing, and mass transfer is not efficient in the valorization of lignocellulosic biomass (Weiss et al., 2019). Determining the concentration limits for cell disruption methods is of critical importance to select operational conditions where energy input is minimal without compromising the extraction efficiency. This limit should also be correlated to the requirements of the harvesting method in order to reduce the energy input of biomass concentration and dewatering. In this respect, energy intensive dewatering operations to very high solids content may only be required for applications of microalgae for direct use as feed or as food supplements in the form of pills and powders.

Harvesting and dewatering of microalgae biomass can become more efficient by combination of methods. Initial preconcentration by simple and low-cost methods such as gravitation settling can be extremely beneficial in terms of cost and energy requirements. Therefore, selection of suitable microalgae strains with high sedimentation velocities and ability to accumulate the desired biomolecules is paramount. The initial microalgae species selection can provide considerable cost, energy and time savings, as these methods are much more efficient when applied to moderately weak cell walls. Flocculation and membrane filtration are also promising preconcentration methods and combined with efficient dewatering processes such as centrifugation can reduce energy and cost requirements. The effect of upscaling of the harvesting and dewatering operations on energy efficiency also has to be considered.

Among emerging microalgae pretreatment methods thermal such as hydrothermal and steam explosion, dilute acid and alkaline hydrolysis are interesting due to the ability for fast and efficient cell disruption and fractionation of biomass components. Optimization and easy correlation of yield and energy requirements with process parameters such as time, temperature and $\mathrm{pH}$ with a single severity factor is also attractive. Viscosity reduction through hydrolytic reactions of macromolecules can enable such methods to handle increased solids concentrations of microalgal biomass. Energy recovery through heat exchange is an additional benefit. Enzymatic pretreatment is very promising due to the low energy requirements selectivity and the non-destructive nature of the process that can preserve the bioactive properties of the isolated molecules. Explosive decompression of microalgal cells pressurized by a gas such as $\mathrm{CO}_{2}$ and $\mathrm{N}_{2}$ is also interesting, although it has not been yet extensively studied. The mode of action is similar to steam explosion, but the lack of heat may make the method viable for the isolation of sensitive molecules such as pigments and antioxidants. 
Among the most interesting methods, however, are those combining harvesting with pretreatment such as electroflocculation, ozonoflotation, and chemical flocculation with iron and oxidation through Fenton reaction by addition of $\mathrm{H}_{2} \mathrm{O}_{2}$. Even if these methods fail to reach industrial maturity, the reduction of unit operation can provide significant benefits in terms of investment and operating costs. Similar strategies may prove critical for the implementation of a mature microalgae biorefinery in the future.

CRediT author statement

Christos Nitsos: Investigation, Writing - Original Draft, Visualization, Rayen Filali:

Conceptualization, Writing - Review \& Editing, Visualization, Behnam Taidi:

Conceptualization, Writing - Review \& Editing, Supervision, Julien Lemaire:

Conceptualization, Writing - Review \& Editing

\section{Acknowledgments}

This study was carried out in the Centre Européen de Biotechnologie et de Bioéconomie (CEBB), supported by Région Grand Est, Département de la Marne, Grand Reims and the European Union. Authors are grateful to Pr. PERRE Patrick, director of the Chair of Biotechnology of CentraleSupélec for funding all the works of this article.

\section{References}

Abbaszadegan, A., Ghahramani, Y., Gholami, A., Hemmateenejad, B., Dorostkar, S., Nabavizadeh, M., Sharghi, H., 2015. The Effect of Charge at the Surface of Silver Nanoparticles on Antimicrobial Activity against Gram-Positive and Gram-Negative Bacteria: A Preliminary Study [WWW Document]. J. Nanomater. https://doi.org/10.1155/2015/720654

Abdel-Raouf, N., Al-Homaidan, A.A., Ibraheem, I.B.M., 2012. Microalgae and wastewater treatment. Saudi J. Biol. Sci. 19, 257-275. https://doi.org/10.1016/j.sjbs.2012.04.005

Abdul Razack, S., Duraiarasan, S., Mani, V., 2016. Biosynthesis of silver nanoparticle and its application in cell wall disruption to release carbohydrate and lipid from C. vulgaris for biofuel production. Biotechnol. Rep. 11, 70-76. https://doi.org/10.1016/j.btre.2016.07.001

Acién, F.G., Molina, E., Reis, A., Torzillo, G., Zittelli, G.C., Sepúlveda, C., Masojídek, J., 2017. 1 - Photobioreactors for the production of microalgae, in: Gonzalez-Fernandez, C., Muñoz, R. (Eds.), Microalgae-Based Biofuels and Bioproducts, Woodhead Publishing Series in Energy. Woodhead Publishing, pp. 1-44. https://doi.org/10.1016/B978-0-08-101023-5.00001-7

Adesanya, V.O., Cadena, E., Scott, S.A., Smith, A.G., 2014. Life cycle assessment on microalgal biodiesel production using a hybrid cultivation system. Bioresour. Technol. 163, 343-355. https://doi.org/10.1016/j.biortech.2014.04.051

Akao, P.K., Cohen-Yaniv, V., Peretz, R., Kinel-Tahan, Y., Yehoshua, Y., Mamane, H., 2019. Effect of ozonation on Spirulina platensis filaments by dynamic imaging particle analysis. Biomass Bioenergy 127, 105247. https://doi.org/10.1016/j.biombioe.2019.05.016

Alhattab, M., Brooks, M.S.-L., 2017. Dispersed air flotation and foam fractionation for the recovery of microalgae in the production of biodiesel. Sep. Sci. Technol. 52, 20022016. https://doi.org/10.1080/01496395.2017.1308957 
Alhattab, M., Kermanshahi-pour, A., Su-Ling Brooks, M., 2019. Dispersed air flotation of Chlorella saccharophila and subsequent extraction of lipids - Effect of supercritical CO2 extraction parameters and surfactant pretreatment. Biomass Bioenergy 127, 105297. https://doi.org/10.1016/j.biombioe.2019.105297

Al-Zuhair, S., Ashraf, S., Hisaindee, S., Darmaki, N.A., Battah, S., Svistunenko, D., Reeder, B., Stanway, G., Chaudhary, A., 2017. Enzymatic pre-treatment of microalgae cells for enhanced extraction of proteins. Eng. Life Sci. 17, 175-185. https://doi.org/10.1002/elsc.201600127

Amaro, H.M., Sousa-Pinto, I., Malcata, F.X., Guedes, A.C., 2017. 16 - Microalgal fatty acids-From harvesting until extraction, in: Gonzalez-Fernandez, C., Muñoz, R. (Eds.), Microalgae-Based Biofuels and Bioproducts, Woodhead Publishing Series in Energy. Woodhead Publishing, pp. 369-400. https://doi.org/10.1016/B978-0-08101023-5.00016-9

Ansari, F.A., Gupta, S.K., Nasr, M., Rawat, I., Bux, F., 2018. Evaluation of various cell drying and disruption techniques for sustainable metabolite extractions from microalgae grown in wastewater: A multivariate approach. J. Clean. Prod. 182, 634643. https://doi.org/10.1016/j.jclepro.2018.02.098

Antwi, E., Engler, N., Nelles, M., Schüch, A., 2019. Anaerobic digestion and the effect of hydrothermal pretreatment on the biogas yield of cocoa pods residues. Waste Manag. 88, 131-140. https://doi.org/10.1016/j.wasman.2019.03.034

Araujo, G.S., Matos, L.J.B.L., Fernandes, J.O., Cartaxo, S.J.M., Gonçalves, L.R.B., Fernandes, F.A.N., Farias, W.R.L., 2013. Extraction of lipids from microalgae by ultrasound application: Prospection of the optimal extraction method. Ultrason. Sonochem. 20, 95-98. https://doi.org/10.1016/j.ultsonch.2012.07.027

Araya, B., Gouveia, L., Nobre, B., Reis, A., Chamy, R., Poirrier, P., 2014. Evaluation of the simultaneous production of lutein and lipids using a vertical alveolar panel bioreactor for three Chlorella species. Algal Res. 6, 218-222. https://doi.org/10.1016/j.algal.2014.06.003

Arun, J., 2017. Ultrasound assisted enhanced extraction of lutein ( $\beta, \varepsilon$-carotene-3 , 3 '-diol ) from Mircroalga ( Chlorella pyrenoidosa) grown in wastewater : Optimization through Response Surface Methodology. https://doi.org/10.30955/gnj.002415

Azaman, S.N.A., Nagao, N., Yusoff, F.M., Tan, S.W., Yeap, S.K., 2017. A comparison of the morphological and biochemical characteristics of Chlorella sorokiniana and Chlorella zofingiensis cultured under photoautotrophic and mixotrophic conditions. PeerJ 5. https://doi.org/10.7717/peerj.3473

Badvipour, S., Eustance, E., Sommerfeld, M.R., 2016. Process evaluation of energy requirements for feed production using dairy wastewater for algal cultivation: Theoretical approach. Algal Res. 19, 207-214. https://doi.org/10.1016/j.algal.2016.08.017

Bai, Y., Huo, Z.-Y., Wu, Y.-H., Hu, H.-Y., 2019. Efficient nanowire-assisted electroporation and cellular inclusion release of microalgal cells achieved by a low voltage. Sci. Total Environ. 667, 191-196. https://doi.org/10.1016/j.scitotenv.2019.02.337Balasundaram, B., Skill, S.C., Llewellyn, C.A., 2012. A low energy process for the recovery of bioproducts from cyanobacteria using a ball mill. Biochem. Eng. J. 69, 48-56. https://doi.org/10.1016/j.bej.2012.08.010

Balduyck, L., Bruneel, C., Goiris, K., Dejonghe, C., Foubert, I., 2018. Influence of High Pressure Homogenization on Free Fatty Acid Formation in Nannochloropsis sp. Eur. J. Lipid Sci. Technol. 120, 1700436. https://doi.org/10.1002/ejlt.201700436

Baroni, É.G., Yap, K.Y., Webley, P.A., Scales, P.J., Martin, G.J.O., 2019. The effect of nitrogen depletion on the cell size, shape, density and gravitational settling of 
Nannochloropsis salina, Chlorella sp. (marine) and Haematococcus pluvialis. Algal Res. 39, 101454. https://doi.org/10.1016/j.algal.2019.101454

Baudelet, P.-H., Ricochon, G., Linder, M., Muniglia, L., 2017. A new insight into cell walls of Chlorophyta. Algal Res. 25, 333-371. https://doi.org/10.1016/j.algal.2017.04.008

Ben Amor-Ben Ayed, H., Taidi, B., Ayadi, H., Pareau, D., Stambouli, M., 2016. Magnesium Uptake by the Green Microalga Chlorella vulgaris in Batch Cultures. J. Microbiol. Biotechnol. 26, 503-510. https://doi.org/10.4014/jmb.1507.07039

Ben Amor-Ben Ayed, H., Taidi, B., Ayadi, H., Pareau, D., Stambouli, M., 2015. Effect of magnesium ion concentration in autotrophic cultures of Chlorella vulgaris. Algal Res.Biomass Biofuels Bioprod. 9, 291-296. https://doi.org/10.1016/j.algal.2015.03.021

Ben Ayed, H.B.A., Taidi, Behnam, Ayadi H, Pareau D, Stambouli M, 2017. The Use of Chlorella Vulgaris to Accumulate Magnesium under Different Culture Conditions. J. Appl. Biotechnol. Bioeng. 2. https://doi.org/10.15406/jabb.2017.02.00043

Bernaerts, T.M.M., Panozzo, A., Doumen, V., Foubert, I., Gheysen, L., Goiris, K., Moldenaers, P., Hendrickx, M.E., Van Loey, A.M., 2017. Microalgal biomass as a (multi)functional ingredient in food products: Rheological properties of microalgal suspensions as affected by mechanical and thermal processing. Algal Res. 25, 452463. https://doi.org/10.1016/j.algal.2017.05.014

Bernaerts, T.M.M., Panozzo, A., Verhaegen, K.A.F., Gheysen, L., Foubert, I., Moldenaers, P., Hendrickx, M.E., Loey, A.M.V., 2018. Impact of different sequences of mechanical and thermal processing on the rheological properties of Porphyridium cruentum and Chlorella vulgaris as functional food ingredients. Food Funct. 9, 2433-2446. https://doi.org/10.1039/C8FO00261D

Besson, A., Formosa-Dague, C., Guiraud, P., 2019. Flocculation-flotation harvesting mechanism of Dunaliella salina: From nanoscale interpretation to industrial optimization. Water Res. 155, 352-361. https://doi.org/10.1016/j.watres.2019.02.043

Bousquet, O., Sellier, N., Le Goffic, F., 1994. Characterization and purification of polyunsaturated fatty acids from microalgae by gas chromatography-mass spectrometry and countercurrent chromatography. Chromatographia 39, 40-44. https://doi.org/10.1007/BF02320456

Byreddy, A.R., Barrow, C.J., Puri, M., 2016. Bead milling for lipid recovery from thraustochytrid cells and selective hydrolysis of Schizochytrium DT3 oil using lipase. Bioresour. Technol. 200, 464-469. https://doi.org/10.1016/j.biortech.2015.10.019

Cardeña, R., Moreno, G., Bakonyi, P., Buitrón, G., 2017. Enhancement of methane production from various microalgae cultures via novel ozonation pretreatment. Chem. Eng. J. 307, 948-954. https://doi.org/10.1016/j.cej.2016.09.016

Carullo, D., Abera, B.D., Casazza, A.A., Donsì, F., Perego, P., Ferrari, G., Pataro, G., 2018. Effect of pulsed electric fields and high pressure homogenization on the aqueous extraction of intracellular compounds from the microalgae Chlorella vulgaris. Algal Res. 31, 60-69. https://doi.org/10.1016/j.algal.2018.01.017

Carvalho, A.P., Silva, S.O., Baptista, J.M., Malcata, F.X., 2011. Light requirements in microalgal photobioreactors: an overview of biophotonic aspects. Appl. Microbiol. Biotechnol. 89, 1275-1288. https://doi.org/10.1007/s00253-010-3047-8

Cerón, M.C., Campos, I., Sánchez, J.F., Acién, F.G., Molina, E., Fernández-Sevilla, J.M., 2008. Recovery of lutein from microalgae biomass: development of a process for Scenedesmus almeriensis biomass. J. Agric. Food Chem. 56, 11761-11766. https://doi.org/10.1021/jf8025875

Chatsungnoen, T., Chisti, Y., 2016. Continuous flocculation-sedimentation for harvesting Nannochloropsis salina biomass. J. Biotechnol. 222, 94-103. https://doi.org/10.1016/j.jbiotec.2016.02.020 
Chen, C.-Y., Bai, M.-D., Chang, J.-S., 2013. Improving microalgal oil collecting efficiency by pretreating the microalgal cell wall with destructive bacteria. Biochem. Eng. J. 81, 170-176. https://doi.org/10.1016/j.bej.2013.10.014

Chen, H., Fu, Q., Liao, Q., Xiao, C., Huang, Y., Xia, A., Zhu, X., Kang, Z., 2019a. Rheokinetics of microalgae slurry during hydrothermal pretreatment processes. Bioresour. Technol. 289, 121650. https://doi.org/10.1016/j.biortech.2019.121650

Chen, H., Fu, Q., Liao, Q., Zhang, H., Huang, Y., Xia, A., Zhu, X., 2018. Rheological properties of microalgae slurry for application in hydrothermal pretreatment systems. Bioresour. Technol. 249, 599-604. https://doi.org/10.1016/j.biortech.2017.10.051

Chen, H., Liao, Q., Fu, Q., Huang, Y., Xia, A., Xiao, C., Zhu, X., 2019b. Convective heat transfer characteristics of microalgae slurries in a circular tube flow. Int. J. Heat Mass Transf. 137, 823-834. https://doi.org/10.1016/j.ijheatmasstransfer.2019.03.166

Chen, Q., Liu, D., Wu, C., Xu, A., Xia, W., Wang, Z., Wen, F., Yu, D., 2017. Influence of a facile pretreatment process on lipid extraction from Nannochloropsis sp. through an enzymatic hydrolysis reaction. RSC Adv. 7, 53270-53277. https://doi.org/10.1039/C7RA11483D

Chen, Y.-H., Walker, T.H., 2011. Biomass and lipid production of heterotrophic microalgae Chlorella protothecoides by using biodiesel-derived crude glycerol. Biotechnol. Lett. 33, 1973. https://doi.org/10.1007/s10529-011-0672-y

Chen, Z., Wang, L., Qiu, S., Ge, S., 2018. Determination of Microalgal Lipid Content and Fatty Acid for Biofuel Production [WWW Document]. BioMed Res. Int. https://doi.org/10.1155/2018/1503126

Cheng, C.-H., Du, T.-B., Pi, H.-C., Jang, S.-M., Lin, Y.-H., Lee, H.-T., 2011. Comparative study of lipid extraction from microalgae by organic solvent and supercritical CO2. Bioresour. Technol. 102, 10151-10153. https://doi.org/10.1016/j.biortech.2011.08.064 Cheng, J., Huang, R., Li, T., Zhou, J., Cen, K., 2015. Physicochemical characterization of wet microalgal cells disrupted with instant catapult steam explosion for lipid extraction. Bioresour. Technol. 191, 66-72. https://doi.org/10.1016/j.biortech.2015.05.005

Cheng, J., Sun, J., Huang, Y., Zhou, J., Cen, K., 2014. Fractal microstructure characterization of wet microalgal cells disrupted with ultrasonic cavitation for lipid extraction. Bioresour. Technol. 170, 138-143. https://doi.org/10.1016/j.biortech.2014.07.090

Cheng, Y., Zhou, W., Gao, C., Lan, K., Gao, Y., Wu, Q., 2009. Biodiesel production from Jerusalem artichoke (Helianthus Tuberosus L.) tuber by heterotrophic microalgae Chlorella protothecoides. J. Chem. Technol. Biotechnol. 84, 777-781. https://doi.org/10.1002/jctb.2111

Cheng, Y.-S., Labavitch, J., VanderGheynst, J.S., 2015. Organic and Inorganic Nitrogen Impact Chlorella variabilis Productivity and Host Quality for Viral Production and Cell Lysis. Appl. Biochem. Biotechnol. 176, 467-479. https://doi.org/10.1007/s12010015-1588-0

Cheng, Y.-S., Zheng, Y., Labavitch, J.M., VanderGheynst, J.S., 2013. Virus infection of Chlorella variabilis and enzymatic saccharification of algal biomass for bioethanol production. Bioresour. Technol. 137, 326-331. https://doi.org/10.1016/j.biortech.2013.03.055

Cheng, X., Riordon, J., Nguyen, B., Ooms, M.D., Sinton, D., 2017. Hydrothermal disruption of algae cells for astaxanthin extraction. Green Chem. 19, 106-111. https://doi.org/10.1039/C6GC02746F

Chia, S.R., Chew, K.W., Zaid, H.F.M., Chu, D.-T., Tao, Y., Show, P.L., 2019. Microalgal Protein Extraction From Chlorella vulgaris FSP-E Using Triphasic Partitioning Technique With Sonication. Front. Bioeng. Biotechnol. 7. https://doi.org/10.3389/fbioe.2019.00396 
Choi, S.P., Nguyen, M.T., Sim, S.J., 2010. Enzymatic pretreatment of Chlamydomonas reinhardtii biomass for ethanol production. Bioresour. Technol. 101, 5330-5336. https://doi.org/10.1016/j.biortech.2010.02.026

Chisti Y., Moo-Young M., Disruption of microbial cells for intracellular products, 1986, Enzyme and Microbial Technology 8, 194-204. https://doi.org/10.1016/01410229(86)90087-6

Chtourou, H., Dahmen, I., Jebali, A., Karray, F., Hassairi, I., Abdelkafi, S., Ayadi, H., Sayadi, S., Dhouib, A., 2015. Characterization of Amphora sp., a newly isolated diatom wild strain, potentially usable for biodiesel production. Bioprocess Biosyst. Eng. 38, 13811392. https://doi.org/10.1007/s00449-015-1379-6

Chu, S., Cui, Y., Liu, N., 2017. The path towards sustainable energy. Nat. Mater. 16, 16-22. https://doi.org/10.1038/nmat 4834

Ciudad, G., Rubilar, O., Azócar, L., Toro, C., Cea, M., Torres, Á., Ribera, A., Navia, R., 2014. Performance of an enzymatic extract in Botrycoccus braunii cell wall disruption. J. Biosci. Bioeng. 117, 75-80. https://doi.org/10.1016/j.jbiosc.2013.06.012

Clement-Larosiere, B., Lopes, F., Goncalves, A., Taidi, B., Benedetti, M., Minier, M., Pareau, D., 2014. Carbon dioxide biofixation by Chlorella vulgaris at different CO2 concentrations and light intensities. Eng. Life Sci. 14, 509-519. https://doi.org/10.1002/elsc.201200212

Collet, P., Hélias, A., Lardon, L., Ras, M., Goy, R.-A., Steyer, J.-P., 2011. Life-cycle assessment of microalgae culture coupled to biogas production. Bioresour. Technol., Special Issue: Biofuels - II: Algal Biofuels and Microbial Fuel Cells 102, 207-214. https://doi.org/10.1016/j.biortech.2010.06.154

Collotta, M., Champagne, P., Mabee, W., Tomasoni, G., Leite, G.B., Busi, L., Alberti, M., 2017. Comparative LCA of Flocculation for the Harvesting of Microalgae for Biofuels Production. Procedia CIRP, The 24th CIRP Conference on Life Cycle Engineering 61, 756-760. https://doi.org/10.1016/j.procir.2016.11.146

Concas, A., Pisu, M., Cao, G., 2015a. Microalgal cell disruption through fenton reaction: experiments, modeling and remarks on its effect on the extracted lipids composition. Chem. Eng. Trans. 43, 367-372. https://doi.org/10.3303/CET1543062

Concas, A., Pisu, M., Cao, G., 2015b. Disruption of microalgal cells for lipid extraction through Fenton reaction: Modeling of experiments and remarks on its effect on lipids composition. Chem. Eng. J. 263, 392-401. https://doi.org/10.1016/j.cej.2014.11.012

Córdova, O., Passos, F., Chamy, R., 2018. Physical Pretreatment Methods for Improving Microalgae Anaerobic Biodegradability. Appl. Biochem. Biotechnol. 185, 114-126. https://doi.org/10.1007/s12010-017-2646-6

Costa, G., Plazanet, I., 2016. Plant Cell Wall, a Challenge for Its Characterisation. Adv. Biol. Chem. 6, 70-105. https://doi.org/10.4236/abc.2016.63008

Coward, T., Lee, J.G.M., Caldwell, G.S., 2014. Harvesting microalgae by CTAB-aided foam flotation increases lipid recovery and improves fatty acid methyl ester characteristics. Biomass Bioenergy 67, 354-362. https://doi.org/10.1016/j.biombioe.2014.05.019

Cuellar-Bermudez, S.P., Aguilar-Hernandez, I., Cardenas-Chavez, D.L., Ornelas-Soto, N., Romero-Ogawa, M.A., Parra-Saldivar, R., 2015. Extraction and purification of highvalue metabolites from microalgae: essential lipids, astaxanthin and phycobiliproteins. Microb. Biotechnol. 8, 190-209. https://doi.org/10.1111/1751-7915.12167

Cuellar-Bermudez, S.P., Kilimtzdi, E., Devaere, J., Goiris, K., Gonzalez-Fernandez, C., Wattiez, R., Muylaert, K., 2019. Harvesting of Arthrospira platensis with helicoidal and straight trichomes using filtration and centrifugation. Sep. Sci. Technol. 0, 1-10. https://doi.org/10.1080/01496395.2019.1624573 
Dahiya, A. (Ed.), 2020. Chapter 28 - Reducing enzyme costs, novel combinations, and advantages of enzymes could lead to improved cost-effective biofuels' production, in: Bioenergy (Second Edition). Academic Press, pp. 573-579. https://doi.org/10.1016/B978-0-12-815497-7.00028-2

Danquah, M.K., Ang, L., Uduman, N., Moheimani, N., Forde, G.M., 2009. Dewatering of microalgal culture for biodiesel production: exploring polymer flocculation and tangential flow filtration. J. Chem. Technol. Biotechnol. 84, 1078-1083. https://doi.org/10.1002/jctb.2137

Das, P., Thaher, M., Khan, S., AbdulQuadir, M., Al-Jabri, H., 2019. The effect of culture salinity on the harvesting of microalgae biomass using pilot-scale tangential-flowfilter membrane. Bioresour. Technol. 293, 122057. https://doi.org/10.1016/j.biortech.2019.122057

de Farias Silva, C.E., Meneghello, D., de Souza Abud, A.K., Bertucco, A., 2020. Pretreatment of microalgal biomass to improve the enzymatic hydrolysis of carbohydrates by ultrasonication: Yield vs energy consumption. J. King Saud Univ. - Sci. 32, 606-613. https://doi.org/10.1016/j.jksus.2018.09.007

Delgadillo-Mirquez, L., Lopes, F., Taidi, B., Pareau, D., 2016. Nitrogen and phosphate removal from wastewater with a mixed microalgae and bacteria culture. Biotechnol. Rep. 11, 18-26. https://doi.org/10.1016/j.btre.2016.04.003

Demirbas, M.F., Balat, M., Balat, H., 2009. Potential contribution of biomass to the sustainable energy development. Energy Convers. Manag. 50, 1746-1760. https://doi.org/10.1016/j.enconman.2009.03.013

Depraetere, O., Pierre, G., Deschoenmaeker, F., Badri, H., Foubert, I., Leys, N., Markou, G., Wattiez, R., Michaud, P., Muylaert, K., 2015. Harvesting carbohydrate-rich Arthrospira platensis by spontaneous settling. Bioresour. Technol. 180, 16-21. https://doi.org/10.1016/j.biortech.2014.12.084

Di Serio, M., Tesser, R., Santacesaria, E., 2001. A kinetic and mass transfer model to simulate the growth of baker's yeast in industrial bioreactors. Chem. Eng. J., FRONTIERS IN CHEMICAL REACTION ENGINEERING 82, 347-354. https://doi.org/10.1016/S1385-8947(00)00353-3

Doucha, J., Lívanský, K., 2008. Influence of processing parameters on disintegration of Chlorella cells in various types of homogenizers. Appl. Microbiol. Biotechnol. 81, 431. https://doi.org/10.1007/s00253-008-1660-6

Duan, Z., Tan, X., Dai, K., Gu, H., Yang, H., 2017. Evaluation on H2O2-aided ultrasonic pretreatment for cell disruption of Chlorella pyrenoidosa. Asia-Pac. J. Chem. Eng. 12, 502-510. https://doi.org/10.1002/apj.2093

Duan, Zhipeng, Tan, X., Guo, J., Kahehu, C.W., Yang, H., Zheng, X., Zhu, F., 2017. Effects of biological and physical properties of microalgae on disruption induced by a lowfrequency ultrasound. J. Appl. Phycol. 29, 2937-2946. https://doi.org/10.1007/s10811-017-1178-3

Eing, C., Goettel, M., Straessner, R., Gusbeth, C., Frey, W., 2013. Pulsed Electric Field Treatment of Microalgae-Benefits for Microalgae Biomass Processing. IEEE Trans. Plasma Sci. 41, 2901-2907. https://doi.org/10.1109/TPS.2013.2274805

Elcik, H., Cakmakci, M., 2017. Harvesting of microalgae via submerged membranes: flux, fouling and its reversibility. Membr. Water Treat. 8, 499-515. https://doi.org/10.12989/mwt.2017.8.5.499

Elcik, H., Cakmakci, M., Ozkaya, B., 2017. Preparation and characterisation of novel polysulfone membranes modified with Pluronic F-127 for reducing microalgal fouling. Chem. Pap. 71, 1271-1290. https://doi.org/10.1007/s11696-016-0120-5 
Fábryová, T., Cheel, J., Kubáč, D., Hrouzek, P., Vu, D.L., Tůmová, L., Kopecký, J., 2019. Purification of lutein from the green microalgae Chlorella vulgaris by integrated use of a new extraction protocol and a multi-injection high performance counter-current chromatography (HPCCC). Algal Res. 41, 101574. https://doi.org/10.1016/j.algal.2019.101574

Fan, J., Zheng, L., Bai, Y., Saroussi, S., Grossman, A.R., 2017. Flocculation of Chlamydomonas reinhardtii with Different Phenotypic Traits by Metal Cations and High pH. Front. Plant Sci. 8. https://doi.org/10.3389/fpls.2017.01997

Fasaei, F., Bitter, J.H., Slegers, P.M., van Boxtel, A.J.B., 2018. Techno-economic evaluation of microalgae harvesting and dewatering systems. Algal Res. 31, 347-362. https://doi.org/10.1016/j.algal.2017.11.038Filali, R., Taidi, B., Pareau, D., 2019. Optimization of a raceway pond system for wastewater treatment: a review. Crit. Rev. Biotechnol. 39, 422-435. https://doi.org/10.1080/07388551.2019.1571007

Florentino de Souza Silva, A.P., Costa, M.C., Colzi Lopes, A., Fares Abdala Neto, E., Carrhá Leitão, R., Mota, C.R., Bezerra dos Santos, A., 2014. Comparison of pretreatment methods for total lipids extraction from mixed microalgae. Renew. Energy 63, 762766. https://doi.org/10.1016/j.renene.2013.10.038

Fu, Q., Zhang, H., Chen, H., Liao, Q., Xia, A., Huang, Y., Zhu, X., Reungsang, A., Liu, Z., 2018. Hydrothermal hydrolysis pretreatment of microalgae slurries in a continuous reactor under subcritical conditions for large-scale application. Bioresour. Technol. 266, 306-314. https://doi.org/10.1016/j.biortech.2018.06.088

García-Cubero, M.T., González-Benito, G., Indacoechea, I., Coca, M., Bolado, S., 2009. Effect of ozonolysis pretreatment on enzymatic digestibility of wheat and rye straw. Bioresour. Technol. 100, 1608-1613. https://doi.org/10.1016/j.biortech.2008.09.012

Garrote, G., Domínguez, H., Parajó, J.C., 1999. Hydrothermal processing of lignocellulosic materials. Holz Als Roh- Werkst. 57, 191-202. https://doi.org/10.1007/s001070050039

Gayen, K., Bhowmick, T.K., Maity, S.K., Bhowmick, T.K., Maity, S.K., 2019. Sustainable Downstream Processing of Microalgae for Industrial Application. CRC Press. https://doi.org/10.1201/9780429027970

Gerde, J.A., Montalbo-Lomboy, M., Yao, L., Grewell, D., Wang, T., 2012. Evaluation of microalgae cell disruption by ultrasonic treatment. Bioresour. Technol. 125, 175-181. https://doi.org/10.1016/j.biortech.2012.08.110

Gerken, H.G., Donohoe, B., Knoshaug, E.P., 2013. Enzymatic cell wall degradation of Chlorellavulgaris and other microalgae for biofuels production. Planta 237, 239-253. https://doi.org/10.1007/s00425-012-1765-0

Giorno, F., Mazzei, R., Giorno, L., 2013. Purification of triacylglycerols for biodiesel production from Nannochloropsis microalgae by membrane technology. Bioresour. Technol. 140, 172-178. https://doi.org/10.1016/j.biortech.2013.04.073

Gonçalves, A.L., Pires, J.C.M., Simões, M., 2017. A review on the use of microalgal consortia for wastewater treatment. Algal Res., Wastewater and Algae; opportunities, challenges and long term sustainability $24,403-415$. https://doi.org/10.1016/j.algal.2016.11.008

Granados, M.R., Acién, F.G., Gómez, C., Fernández-Sevilla, J.M., Molina Grima, E., 2012. Evaluation of flocculants for the recovery of freshwater microalgae. Bioresour. Technol. 118, 102-110. https://doi.org/10.1016/j.biortech.2012.05.018

Greenly, J.M., Tester, J.W., 2015. Ultrasonic cavitation for disruption of microalgae. Bioresour. Technol., Advances in biofuels and chemicals from algae 184, 276-279. https://doi.org/10.1016/j.biortech.2014.11.036 
Grimi, N., Dubois, A., Marchal, L., Jubeau, S., Lebovka, N.I., Vorobiev, E., 2014. Selective extraction from microalgae Nannochloropsis sp. using different methods of cell disruption. Bioresour. Technol. 153, 254-259. https://doi.org/10.1016/j.biortech.2013.12.011

Gügi, B., Le Costaouec, T., Burel, C., Lerouge, P., Helbert, W., Bardor, M., 2015. DiatomSpecific Oligosaccharide and Polysaccharide Structures Help to Unravel Biosynthetic Capabilities in Diatoms. Mar. Drugs 13, 5993-6018. https://doi.org/10.3390/md13095993

Guionet, A., Oura, K., Akiyama, H., Hosano, H., 2019. The narrow window of energy application for oil extraction by arc discharge. J. Appl. Phycol. 31, 89-96. https://doi.org/10.1007/s10811-018-1579-y

Guldhe, A., Misra, R., Singh, P., Rawat, I., Bux, F., 2016. An innovative electrochemical process to alleviate the challenges for harvesting of small size microalgae by using non-sacrificial carbon electrodes. Algal Res. 19, 292-298. https://doi.org/10.1016/j.algal.2015.08.014

Guldhe, A., Singh, B., Rawat, I., Ramluckan, K., Bux, F., 2014. Efficacy of drying and cell disruption techniques on lipid recovery from microalgae for biodiesel production. Fuel 128, 46-52. https://doi.org/10.1016/j.fuel.2014.02.059

Günerken, E., D’Hondt, E., Eppink, M.H.M., Garcia-Gonzalez, L., Elst, K., Wijffels, R.H., 2015a. Cell disruption for microalgae biorefineries. Biotechnol. Adv. 33, 243-260. https://doi.org/10.1016/j.biotechadv.2015.01.008

Günerken, E., D’Hondt, E., Eppink, M.H.M., Garcia-Gonzalez, L., Elst, K., Wijffels, R.H., 2015b. Cell disruption for microalgae biorefineries. Biotechnol. Adv. 33, 243-260. https://doi.org/10.1016/j.biotechadv.2015.01.008

Günerken, E., D’Hondt, E., Eppink, M.H.M., Wijffels, R.H., Elst, K., 2019. Disruption of microalgae with a novel continuous explosive decompression device. Algal Res. 39, 101376. https://doi.org/10.1016/j.algal.2018.12.001

Günther, S., Gernat, D., Overbeck, A., Kampen, I., Kwade, A., 2016. Micromechanical Properties and Energy Requirements of the Microalgae Chlorella vulgaris for Cell Disruption. Chem. Eng. Technol. 39, 1693-1699. https://doi.org/10.1002/ceat.201400632

Hagen, C., Siegmund, S., Braune, W., 2002. Ultrastructural and chemical changes in the cell wall of Haematococcus pluvialis (Volvocales, Chlorophyta) during aplanospore formation. Eur. J. Phycol. 37, 217-226. https://doi.org/10.1017/S0967026202003669

Halim, R., Harun, R., Danquah, M.K., Webley, P.A., 2012. Microalgal cell disruption for biofuel development. Appl. Energy 91, 116-121. https://doi.org/10.1016/j.apenergy.2011.08.048

Halim, R., Rupasinghe, T.W.T., Tull, D.L., Webley, P.A., 2013. Mechanical cell disruption for lipid extraction from microalgal biomass. Bioresour. Technol. 140, 53-63. https://doi.org/10.1016/j.biortech.2013.04.067

Halim, R., Webley, P.A., Martin, G.J.O., 2016. The CIDES process: Fractionation of concentrated microalgal paste for co-production of biofuel, nutraceuticals, and highgrade protein feed. Algal Res. 19, 299-306. https://doi.org/10.1016/j.algal.2015.09.018

Hannon, M., Gimpel, J., Tran, M., Rasala, B., Mayfield, S., 2010. Biofuels from algae: challenges and potential. Biofuels 1, 763-784.

Haque, F., Dutta, A., Thimmanagari, M., Chiang, Y.W., 2016. Intensified green production of astaxanthin from Haematococcus pluvialis. Food Bioprod. Process. 99, 1-11. https://doi.org/10.1016/j.fbp.2016.03.002 
Harith, Z.T., Yusoff, F.M., Mohamed, M.S., Shariff, M., Din, M.S.M., Ariff, A.B., 2009. Effect of different flocculants on the flocculation performance of microalgae, Chaetoceros calcitrans, cells. https://doi.org/10.5897/ajb09.569

Hellebust, J.A., Ahmad, I., 1989. Regulation of Nitrogen Assimilation in Green Microalgae 16.

Hennart, S.L.A., Wildeboer, W.J., van Hee, P., Meesters, G.M.H., 2009. Identification of the grinding mechanisms and their origin in a stirred ball mill using population balances. Chem. Eng. Sci. 64, 4123-4130. https://doi.org/10.1016/j.ces.2009.06.031

Heo, Y.M., Lee, H., Lee, C., Kang, J., Ahn, J.-W., Lee, Y.M., Kang, K.-Y., Choi, Y.-E., Kim, J.-J., 2017. An integrative process for obtaining lipids and glucose from Chlorella vulgaris biomass with a single treatment of cell disruption. Algal Res. 27, 286-294. https://doi.org/10.1016/j.algal.2017.09.022

Hernández, D., Riaño, B., Coca, M., García-González, M.C., 2015. Saccharification of carbohydrates in microalgal biomass by physical, chemical and enzymatic pretreatments as a previous step for bioethanol production. Chem. Eng. J. 262, 939-945. https://doi.org/10.1016/j.cej.2014.10.049

Hom-Diaz, A., Passos, F., Ferrer, I., Vicent, T., Blánquez, P., 2016. Enzymatic pretreatment of microalgae using fungal broth from Trametes versicolor and commercial laccase for improved biogas production. Algal Res. 19, 184-188. https://doi.org/10.1016/j.algal.2016.08.006

T.R. Hopkins, Physical and chemical cell disruption for the recovery of intracellular protein. Chapter 3, R. Seetharam, S. Sharma (Eds.), Purification and analysis of recombinant proteins, Macel Dekker, New York (1991), pp. 57-84

Horvat, J., Klaić, B., Metelko, B., Šunjić, V., 1985. Mechanism of levulinic acid formation. Tetrahedron Lett. 26, 2111-2114. https://doi.org/10.1016/S0040-4039(00)94793-2

Howlader, M.S., French, W.T., Shields-Menard, S.A., Amirsadeghi, M., Green, M., Rai, N., 2017. Microbial cell disruption for improving lipid recovery using pressurized $\mathrm{CO} 2$ : Role of CO2 solubility in cell suspension, sugar broth, and spent media. Biotechnol. Prog. 33, 737-748. https://doi.org/10.1002/btpr.2471

$\mathrm{Hu}$, Y., Gong, M., Xu, C. (Charles), Bassi, A., 2017. Investigation of an alternative cell disruption approach for improving hydrothermal liquefaction of microalgae. Fuel 197, 138-144. https://doi.org/10.1016/j.fuel.2017.02.022

Huang, Y., Hong, A., Zhang, D., Li, L., 2014. Comparison of cell rupturing by ozonation and ultrasonication for algal lipid extraction from Chlorella vulgaris. Environ. Technol. 35, 931-937. https://doi.org/10.1080/09593330.2013.856954

Hung, M.T., Liu, J.C., 2018. Microfiltration of microalgae in the presence of rigid particles. Sep. Purif. Technol., Filtering a Better Future 198, 10-15. https://doi.org/10.1016/j.seppur.2016.10.063

Jaeschke, D.P., Mercali, G.D., Marczak, L.D.F., Müller, G., Frey, W., Gusbeth, C., 2019. Extraction of valuable compounds from Arthrospira platensis using pulsed electric field treatment. Bioresour. Technol. 283, 207-212. https://doi.org/10.1016/j.biortech.2019.03.035

Jana, A., Ghosh, S., Majumdar, S., 2018. Energy efficient harvesting of Arthrospira sp. using ceramic membranes: analyzing the effect of membrane pore size and incorporation of flocculant as fouling control strategy. J. Chem. Technol. Biotechnol. 93, 1085-1096. https://doi.org/10.1002/jctb.5466

Jiang, S., Zhang, Y., Zhao, F., Yu, Z., Zhou, X., Chu, H., 2018. Impact of transmembrane pressure (TMP) on membrane fouling in microalgae harvesting with a uniform 
shearing vibration membrane system. Algal Res. 35, 613-623.

https://doi.org/10.1016/j.algal.2018.10.003

Johansen, J., 1991. Morphological Variability and Cell-Wall Composition of PhaeodactylumTricornutum (bacillariophyceae). Gt. Basin Nat. 51, 310-315.

Juneja, A., Ceballos, R.M., Murthy, G.S., 2013. Effects of Environmental Factors and Nutrient Availability on the Biochemical Composition of Algae for Biofuels Production: A Review. Energies 6, 4607-4638. https://doi.org/10.3390/en6094607

Kalina, T., Zabova, I., Hilgard, S., 1993. The Spectroscopy of the Acetoresistant Cell-Wall Biopolymers of Auxenochlorella-Protothecoides, Scenedesmus-Quadricauda and Chlamydomonas-Geitleri Zygospores (chlorophyta). Arch. Hydrobiol. 65-77.

Kamaroddin, M.F., Hanotu, J., Gilmour, D.J., Zimmerman, W.B., 2016. In-situ disinfection and a new downstream processing scheme from algal harvesting to lipid extraction using ozone-rich microbubbles for biofuel production. Algal Res. 17, 217-226. https://doi.org/10.1016/j.algal.2016.05.006

Kapaun, E., Reisser, W., 1995. A chitin-like glycan in the cell wall of a Chlorella sp. (Chlorococcales, Chlorophyceae). Planta 197, 577-582.

Keris-Sen, U.D., Gurol, M.D., 2017. Using ozone for microalgal cell disruption to improve enzymatic saccharification of cellular carbohydrates. Biomass Bioenergy 105, 59-65. https://doi.org/10.1016/j.biombioe.2017.06.023

Keris-Sen, U.D., Sen, U., Soydemir, G., Gurol, M.D., 2014. An investigation of ultrasound effect on microalgal cell integrity and lipid extraction efficiency. Bioresour. Technol. 152, 407-413. https://doi.org/10.1016/j.biortech.2013.11.018

Khairuddin, N.F.M., Idris, A., Hock, L.W., 2019. Harvesting Nannochloropsis sp. using PES/MWCNT/LiBr membrane with good antifouling properties. Sep. Purif. Technol. 212, 1-11. https://doi.org/10.1016/j.seppur.2018.11.013

Kim, D., Kwak, M., Kim, K., Chang, Y.K., 2019. Turbulent jet-assisted microfiltration for energy efficient harvesting of microalgae. J. Membr. Sci. 575, 170-178. https://doi.org/10.1016/j.memsci.2018.12.069

Kim, G., Mujtaba, G., Lee, K., 2016. Effects of nitrogen sources on cell growth and biochemical composition of marine chlorophyte Tetraselmis sp. for lipid production. ALGAE 31, 257-266. https://doi.org/10.4490/algae.2016.31.8.18

Kim, J.K., Um, B.-H., Kim, T.H., 2012. Bioethanol production from micro-algae, Schizocytrium sp., using hydrothermal treatment and biological conversion. Korean J. Chem. Eng. 29, 209-214. https://doi.org/10.1007/s11814-011-0169-3

Kim, S., Kim, Y.-S., 2018. Chlorella virus-mediated disruption of microalgal cell wall for biodiesel production. Korean J. Microbiol. 54, 140-145. https://doi.org/10.7845/kjm.2018.8020

Krishna Koyande, A., Tanzil, V., Murraly Dharan, H., Subramaniam, M., Robert, R.N., Lau, P.-L., Khoiroh, I., Show, P.-L., 2020. Integration of osmotic shock assisted liquid biphasic system for protein extraction from microalgae Chlorella vulgaris. Biochem. Eng. J. 157, 107532. https://doi.org/10.1016/j.bej.2020.107532

Kröger, M., Klemm, M., Nelles, M., 2018. Hydrothermal Disintegration and Extraction of Different Microalgae Species. Energies 11, 450. https://doi.org/10.3390/en11020450

Krug, J.H.A., 2018. Accounting of GHG emissions and removals from forest management: a long road from Kyoto to Paris. Carbon Balance Manag. 13, 1. https://doi.org/10.1186/s13021-017-0089-6

Kurokawa, M., King, P.M., Wu, X., Joyce, E.M., Mason, T.J., Yamamoto, K., 2016. Effect of sonication frequency on the disruption of algae. Ultrason. Sonochem. 31, 157-162. https://doi.org/10.1016/j.ultsonch.2015.12.011 
Kwade, A., 1999. Determination of the most important grinding mechanism in stirred media mills by calculating stress intensity and stress number. Powder Technol. 105, 382388. https://doi.org/10.1016/S0032-5910(99)00162-X

Laamanen, C.A., Scott, J.A., 2017. Development of heat-aided flocculation for flotation harvesting of microalgae. Biomass Bioenergy 107, 150-154. https://doi.org/10.1016/j.biombioe.2017.09.020

Lam, G.P. 't, 2017. Harvesting and cell disruption of microalgae. https://doi.org/10.18174/412263

Le Costaouëc, T., Unamunzaga, C., Mantecon, L., Helbert, W., 2017. New structural insights into the cell-wall polysaccharide of the diatom Phaeodactylum tricornutum. Algal Res. 26, 172-179. https://doi.org/10.1016/j.algal.2017.07.021

Lee, I., Han, J.-I., 2015a. Simultaneous treatment (cell disruption and lipid extraction) of wet microalgae using hydrodynamic cavitation for enhancing the lipid yield. Bioresour. Technol. 186, 246-251. https://doi.org/10.1016/j.biortech.2015.03.045

Lee, I., Han, J.-I., 2015b. Hydrothermal-acid treatment for effectual extraction of eicosapentaenoic acid (EPA)-abundant lipids from Nannochloropsis salina. Bioresour. Technol. 191, 1-6. https://doi.org/10.1016/j.biortech.2015.04.124

Lee, I., Park, J.-Y., Choi, S.-A., Oh, Y.-K., Han, J.-I., 2014. Hydrothermal nitric acid treatment for effectual lipid extraction from wet microalgae biomass. Bioresour. Technol. 172, 138-142. https://doi.org/10.1016/j.biortech.2014.08.101

Lee, Soo Youn, Cho, J.M., Chang, Y.K., Oh, Y.-K., 2017. Cell disruption and lipid extraction for microalgal biorefineries: A review. Bioresour. Technol., SI:Algal Biorefinery 244, 1317-1328. https://doi.org/10.1016/j.biortech.2017.06.038

Lee, Sze Ying, Show, P.L., Ling, T.C., Chang, J.-S., 2017. Single-step disruption and protein recovery from Chlorella vulgaris using ultrasonication and ionic liquid buffer aqueous solutions as extractive solvents. Biochem. Eng. J. 124, 26-35. https://doi.org/10.1016/j.bej.2017.04.009

Lee, Y.-K., 2001. Microalgal mass culture systems and methods: Their limitation and potential. J. Appl. Phycol. 13, 307-315. https://doi.org/10.1023/A:1017560006941

Lei, X., Chen, Y., Shao, Z., Chen, Z., Li, Y., Zhu, H., Zhang, J., Zheng, W., Zheng, T., 2015. Effective harvesting of the microalgae Chlorella vulgaris via flocculation-flotation with bioflocculant. Bioresour. Technol. 198, 922-925. https://doi.org/10.1016/j.biortech.2015.08.095

Leonhardt, L., Käferböck, A., Smetana, S., de Vos, R., Toepfl, S., Parniakov, O., 2020. Biorefinery of Chlorella sorokiniana with pulsed electric field pre-treatment. Bioresour. Technol. 301, 122743. https://doi.org/10.1016/j.biortech.2020.122743

Letelier-Gordo, C.O., Holdt, S.L., De Francisci, D., Karakashev, D.B., Angelidaki, I., 2014. Effective harvesting of the microalgae Chlorella protothecoides via bioflocculation with cationic starch. Bioresour. Technol. 167, 214-218. https://doi.org/10.1016/j.biortech.2014.06.014

Lewandowski, I., Heinz, A., 2003. Delayed harvest of miscanthus—influences on biomass quantity and quality and environmental impacts of energy production. Eur. J. Agron. 19, 45-63. https://doi.org/10.1016/S1161-0301(02)00018-7

Lin, C.-C., Hong, P.K.A., 2013. A new processing scheme from algae suspension to collected lipid using sand filtration and ozonation. Algal Res. 2, 378-384. https://doi.org/10.1016/j.algal.2013.06.001

Liu, C., Hao, Y., Jiang, J., Liu, W., 2017. Valorization of untreated rice bran towards bioflocculant using a lignocellulose-degrading strain and its use in microalgal biomass harvest. Biotechnol. Biofuels 10, 90. https://doi.org/10.1186/s13068-017-0780-6 
Liu, C.-H., Chang, C.-Y., Cheng, C.-L., Lee, D.-J., Chang, J.-S., 2012. Fermentative hydrogen production by Clostridium butyricum CGS5 using carbohydrate-rich microalgal biomass as feedstock. Int. J. Hydrog. Energy, The 2011 Asian BioHydrogen and Biorefinery Symposium (2011ABBS) 37, 15458-15464. https://doi.org/10.1016/j.ijhydene.2012.04.076

Liu, Z.-W., Zeng, X.-A., Cheng, J.-H., Liu, D.-B., Aadil, R.M., 2018. The efficiency and comparison of novel techniques for cell wall disruption in astaxanthin extraction from Haematococcus pluvialis. Int. J. Food Sci. Technol. 53, 2212-2219. https://doi.org/10.1111/ijfs.13810

Liu, S., Liu, C., Huang, X., Chai, Y., Cong, B., 2006. Optimization of Parameters for Isolation of Protoplasts from the Antarctic Sea Ice Alga Chlamydomonas Sp. ICE-L. J Appl Phycol 18, 783. https://doi.org/10.1007/s10811-006-9093-z

Lorente, E., Farriol, X., Salvadó, J., 2015. Steam explosion as a fractionation step in biofuel production from microalgae. Fuel Process. Technol. 131, 93-98.

https://doi.org/10.1016/j.fuproc.2014.11.009

Lorente, E., Hapońska, M., Clavero, E., Torras, C., Salvadó, J., 2018. Steam Explosion and Vibrating Membrane Filtration to Improve the Processing Cost of Microalgae Cell Disruption and Fractionation. Processes 6, 28. https://doi.org/10.3390/pr6040028

Lorente, E., Hapońska, M., Clavero, E., Torras, C., Salvadó, J., 2017. Microalgae fractionation using steam explosion, dynamic and tangential cross-flow membrane filtration. Bioresour. Technol., 1st International Conference on Bioresource Technology for Bioenergy, Bioproducts \& Environmental Sustainability (BIORESTEC) 237, 3-10. https://doi.org/10.1016/j.biortech.2017.03.129

Luengo, E., Martínez, J.M., Bordetas, A., Álvarez, I., Raso, J., 2015. Influence of the treatment medium temperature on lutein extraction assisted by pulsed electric fields from Chlorella vulgaris. Innov. Food Sci. Emerg. Technol., APPLICATIONS OF PEF FOR FOOD PROCESSING 29, 15-22. https://doi.org/10.1016/j.ifset.2015.02.012

Maga, D., 2017. Life cycle assessment of biomethane produced from microalgae grown in municipal waste water. Biomass Convers. Biorefinery 7, 1-10. https://doi.org/10.1007/s13399-016-0208-8

Mahdy, A., Mendez, L., Ballesteros, M., González-Fernández, C., 2014a. Autohydrolysis and alkaline pretreatment effect on Chlorella vulgaris and Scenedesmus sp. methane production. Energy 78, 48-52. https://doi.org/10.1016/j.energy.2014.05.052

Mahdy, A., Mendez, L., Ballesteros, M., González-Fernández, C., 2014b. Enhanced methane production of Chlorella vulgaris and Chlamydomonas reinhardtii by hydrolytic enzymes addition. Energy Convers. Manag. 85, 551-557. https://doi.org/10.1016/j.enconman.2014.04.097

Martín Juárez, J., Riol Pastor, E., Fernández Sevilla, J.M., Muñoz Torre, R., García-Encina, P.A., Bolado Rodríguez, S., 2018. Effect of pretreatments on biogas production from microalgae biomass grown in pig manure treatment plants. Bioresour. Technol. 257, 30-38. https://doi.org/10.1016/j.biortech.2018.02.063

Martínez, J.M., Gojkovic, Z., Ferro, L., Maza, M., Álvarez, I., Raso, J., Funk, C., 2019. Use of pulsed electric field permeabilization to extract astaxanthin from the Nordic microalga Haematococcus pluvialis. Bioresour. Technol. 289, 121694. https://doi.org/10.1016/j.biortech.2019.121694

Masojídek, J., Torzillo, G., Koblížek, M., 2013. Photosynthesis in Microalgae, in: Handbook of Microalgal Culture. John Wiley \& Sons, Ltd, pp. 21-36. https://doi.org/10.1002/9781118567166.ch2 
Mata, T.M., Mendes, A.M., Caetano, N.S., Martins, A.A., 2014. Sustainability and economic evaluation of microalgae grown in brewery wastewater. Bioresour. Technol., Special Issue on Advance Biological Treatment Technologies for Sustainable Waste Management (ICSWHK2013) 168, 151-158. https://doi.org/10.1016/j.biortech.2014.04.091

Mathimani, T., Mallick, N., 2018. A comprehensive review on harvesting of microalgae for biodiesel - Key challenges and future directions. Renew. Sustain. Energy Rev. 91, 1103-1120. https://doi.org/10.1016/j.rser.2018.04.083

Matos, Â.P., Teixeira, M.S., Corrêa, F.M.P.S., Machado, M.M., Werner, R.I.S., Aguiar, A.C., Cubas, A.L.V., Sant'Anna, E.S., Moecke, E.H.S., 2019. DISRUPTION OF Nannochloropsis gaditana (EUSTIGMATOPHYCEAE) RIGID CELL WALL BY NON-THERMAL PLASMA PRIOR TO LIPID EXTRACTION AND ITS EFFECT ON FATTY ACID COMPOSITION. Braz. J. Chem. Eng. 36, 1419-1428. https://doi.org/10.1590/0104-6632.20190364s20190097

Matter, I.A., Darwesh, O.M., Eida, M.F., 2018. Harvesting of microalgae Scenedesmus obliquus using chitosan-alginate dual flocculation system.

McMillan, J.R., Watson, I.A., Ali, M., Jaafar, W., 2013. Evaluation and comparison of algal cell disruption methods: Microwave, waterbath, blender, ultrasonic and laser treatment. Appl. Energy 103, 128-134. https://doi.org/10.1016/j.apenergy.2012.09.020

Mendes-Pinto, M.M., Raposo, M.F.J., Bowen, J., Young, A.J., Morais, R., 2001. Evaluation of different cell disruption processes on encysted cells of Haematococcus pluvialis: effects on astaxanthin recovery and implications for bio-availability. J. Appl. Phycol. 13, 19-24. https://doi.org/10.1023/A:1008183429747

Mendez, L., Mahdy, A., Timmers, R.A., Ballesteros, M., González-Fernández, C., 2013. Enhancing methane production of Chlorella vulgaris via thermochemical pretreatments. Bioresour. Technol. 149, 136-141. https://doi.org/10.1016/j.biortech.2013.08.136

Milledge, J.J., Heaven, S., 2017. Energy Balance of Biogas Production from Microalgae: Effect of Harvesting Method, Multiple Raceways, Scale of Plant and Combined Heat and Power Generation. J. Mar. Sci. Eng. 5, 9. https://doi.org/10.3390/jmse5010009

Milledge, J.J., Heaven, S., 2011. Disc stack centrifugation separation and cell disruption of microalgae: A technical note. Environ. Nat. Resour. Res. 1, 17-24. https://doi.org/10.5539/enrr.v1n1p17

Molazadeh, M., Ahmadzadeh, H., Pourianfar, H.R., Lyon, S., Rampelotto, P.H., 2019. The Use of Microalgae for Coupling Wastewater Treatment With CO2 Biofixation. Front. Bioeng. Biotechnol. 7. https://doi.org/10.3389/fbioe.2019.00042

Montalescot, V., Rinaldi, T., Touchard, R., Jubeau, S., Frappart, M., Jaouen, P., Bourseau, P., Marchal, L., 2015. Optimization of bead milling parameters for the cell disruption of microalgae: Process modeling and application to Porphyridium cruentum and Nannochloropsis oculata. Bioresour. Technol. 196, 339-346. https://doi.org/10.1016/j.biortech.2015.07.075

Montsant, A., Zarka, A., Boussiba, S., 2001. Presence of a Nonhydrolyzable Biopolymer in the Cell Wall of Vegetative Cells and Astaxanthin-Rich Cysts of Haematococcus pluvialis (Chlorophyceae). Mar. Biotechnol. 3, 515-521. https://doi.org/10.1007/s1012601-0051-0

Mussatto, S.I., Roberto, I.C., 2004. Alternatives for detoxification of diluted-acid lignocellulosic hydrolyzates for use in fermentative processes: a review. Bioresour. Technol. 93, 1-10. https://doi.org/10.1016/j.biortech.2003.10.005 
Muylaert, K., Bastiaens, L., Vandamme, D., Gouveia, L., 2017. 5 - Harvesting of microalgae: Overview of process options and their strengths and drawbacks, in: GonzalezFernandez, C., Muñoz, R. (Eds.), Microalgae-Based Biofuels and Bioproducts, Woodhead Publishing Series in Energy. Woodhead Publishing, pp. 113-132. https://doi.org/10.1016/B978-0-08-101023-5.00005-4

Nascimento, I.A., Marques, S.S.I., Cabanelas, I.T.D., de Carvalho, G.C., Nascimento, M.A., de Souza, C.O., Druzian, J.I., Hussain, J., Liao, W., 2014. Microalgae Versus Land Crops as Feedstock for Biodiesel: Productivity, Quality, and Standard Compliance. BioEnergy Res. 7, 1002-1013. https://doi.org/10.1007/s12155-014-9440-x

Nava Bravo, I., Velásquez-Orta, S.B., Cuevas-García, R., Monje-Ramírez, I., Harvey, A., Orta Ledesma, M.T., 2019. Bio-crude oil production using catalytic hydrothermal liquefaction (HTL) from native microalgae harvested by ozone-flotation. Fuel 241, 255-263. https://doi.org/10.1016/j.fuel.2018.12.071

Neilson, A.H., Lewin, R.A., 1974. The uptake and utilization of organic carbon by algae: an essay in comparative biochemistry. Phycologia 13, 227-264. https://doi.org/10.2216/i0031-8884-13-3-227.1

Němcová, Y., Kalina, T., 2000. Cell wall development, microfibril and pyrenoid structure in type strains of Chlorella vulgaris, C. kessleri, C. sorokiniana compared with C. luteoviridis (Trebouxiophyceae, Chlorophyta). archiv_algolstud 100, 95-105.

https://doi.org/10.1127/algol_stud/100/2000/95

Ngamsirisomsakul, M., Reungsang, A., Liao, Q., Kongkeitkajorn, M.B., 2019. Enhanced bioethanol production from Chlorella sp. biomass by hydrothermal pretreatment and enzymatic hydrolysis. Renew. Energy 141, 482-492. https://doi.org/10.1016/j.renene.2019.04.008

Niaghi, M., Mahdavi, M.A., Gheshlaghi, R., 2015. Optimization of dissolved air flotation technique in harvesting microalgae from treated wastewater without flocculants addition. J. Renew. Sustain. Energy 7, 013130. https://doi.org/10.1063/1.4909541

Nitsos, C.K., Mihailof, C.M., Matis, K.A., Lappas, A.A., Triantafyllidis, K.S., 2013. Chapter 7 - The Role of Catalytic Pretreatment in Biomass Valorization Toward Fuels and Chemicals, in: Triantafyllidis, K.S., Lappas, A.A., Stöcker, M. (Eds.), The Role of Catalysis for the Sustainable Production of Bio-Fuels and Bio-Chemicals. Elsevier, Amsterdam, pp. 217-260. https://doi.org/10.1016/B978-0-444-56330-9.00007-3

Nitsos, C.K., Matis, K.A., Triantafyllidis, K.S., 2013. Optimization of Hydrothermal Pretreatment of Lignocellulosic Biomass in the Bioethanol Production Process. ChemSusChem 6, 110-122. https://doi.org/10.1002/cssc.201200546

Obeid, S., Beaufils, N., Camy, S., Takache, H., Ismail, A., Pontalier, P.-Y., 2018. Supercritical carbon dioxide extraction and fractionation of lipids from freeze-dried microalgae Nannochloropsis oculata and Chlorella vulgaris. Algal Res. 34, 49-56. https://doi.org/10.1016/j.algal.2018.07.003

Olmstead, I.L.D., Kentish, S.E., Scales, P.J., Martin, G.J.O., 2013. Low solvent, low temperature method for extracting biodiesel lipids from concentrated microalgal biomass. Bioresour. Technol. 148, 615-619. https://doi.org/10.1016/j.biortech.2013.09.022

Onay, M., 2019. Bioethanol production via different saccharification strategies from $\mathrm{H}$. tetrachotoma ME03 grown at various concentrations of municipal wastewater in a flatphotobioreactor. Fuel 239, 1315-1323. https://doi.org/10.1016/j.fuel.2018.11.126

Onumaegbu, C., Alaswad, A., Rodriguez, C., Olabi, A.G., 2018. Optimization of PreTreatment Process Parameters to Generate Biodiesel from Microalga. Energies 11, 806. https://doi.org/10.3390/en11040806 
Orlova, T.Yu., Sabutskaya, M.A., Markina, Zh.V., 2019. Ultrastructural Changes in Marine Microalgae from Different Taxonomic Groups during Batch Cultivation. Russ. J. Mar. Biol. 45, 202-210. https://doi.org/10.1134/S1063074019030106

Orr, V.C.A., Plechkova, N.V., Seddon, K.R., Rehmann, L., 2016. Disruption and Wet Extraction of the Microalgae Chlorella vulgaris Using Room-Temperature Ionic Liquids. ACS Sustain. Chem. Eng. 4, 591-600. https://doi.org/10.1021/acssuschemeng.5b00967

Palmqvist, E., Hahn-Hägerdal, B., 2000. Fermentation of lignocellulosic hydrolysates. I: inhibition and detoxification. Bioresour. Technol. 74, 17-24. https://doi.org/10.1016/S0960-8524(99)00160-1

Pan, Z., Huang, Y., Wang, Y., Wu, Z., 2017. Disintegration of Nannochloropsis sp. cells in an improved turbine bead mill. Bioresour. Technol. 245, 641-648. https://doi.org/10.1016/j.biortech.2017.08.146

Paredes-López, O., Camargo-Rubio, E., Ornelas-Vale, A., 1976. Influence of specific growth rate on biomass yield, productivity, and compostion of Candida utilis in batch and continuous culture. Appl. Environ. Microbiol. 31, 487-491.

Park, J.B.K., Craggs, R.J., Shilton, A.N., 2011. Recycling algae to improve species control and harvest efficiency from a high rate algal pond. Water Res. 45, 6637-6649. https://doi.org/10.1016/j.watres.2011.09.042

Passos, F., Carretero, J., Ferrer, I., 2015. Comparing pretreatment methods for improving microalgae anaerobic digestion: Thermal, hydrothermal, microwave and ultrasound. Chem. Eng. J. 279, 667-672. https://doi.org/10.1016/j.cej.2015.05.065

Peperzak, L., 2003. Phytoplankton sinking rates in the Rhine region of freshwater influence. Journal of Plankton Research 25, 365-383. https://doi.org/10.1093/plankt/25.4.365

Phong, W.N., Le, C.F., Show, P.L., Chang, J.-S., Ling, T.C., 2017. Extractive disruption process integration using ultrasonication and an aqueous two-phase system for protein recovery from Chlorella sorokiniana. Eng. Life Sci. 17, 357-369. https://doi.org/10.1002/elsc.201600133

Phong, W.N., Show, P.L., Le, C.F., Tao, Y., Chang, J.-S., Ling, T.C., 2018. Improving cell disruption efficiency to facilitate protein release from microalgae using chemical and mechanical integrated method. Biochem. Eng. J. 135, 83-90. https://doi.org/10.1016/j.bej.2018.04.002

Picart, L., Cheftel, J.-C., 2003. 18 - Pulsed electric fields, in: Zeuthen, P., Bøgh-Sørensen, L. (Eds.), Food Preservation Techniques, Woodhead Publishing Series in Food Science, Technology and Nutrition. Woodhead Publishing, pp. 360-427. https://doi.org/10.1533/9781855737143.3.360

Polat, E., Yüksel, E. \& Altınbaş, M., 2020. Mutual effect of sodium and magnesium on the cultivation of microalgae Auxenochlorella protothecoides. Biomass and Bioenergy 132, 105441.

Postma, P.R., Suarez-Garcia, E., Safi, C., Yonathan, K., Olivieri, G., Barbosa, M.J., Wijffels, R.H., Eppink, M.H.M., 2017. Energy efficient bead milling of microalgae: Effect of bead size on disintegration and release of proteins and carbohydrates. Bioresour. Technol. 224, 670-679. https://doi.org/10.1016/j.biortech.2016.11.071

Qu, Z., Zeng, J., Zhang, Y., Liao, Q., Sharma, B.K., Fu, Q., Huang, Y., Liu, Z., 2018. Hydrothermal cell disruption of Nannochloropsis sp. and its influence on lipid extraction. Algal Res. 35, 407-415. https://doi.org/10.1016/j.algal.2018.09.015

Raja, R., Coelho, A., Hemaiswarya, S., Kumar, P., Carvalho, I.S., Alagarsamy, A., 2018. Applications of microalgal paste and powder as food and feed: An update using text mining tool. Beni-Suef Univ. J. Basic Appl. Sci. 7, 740-747. https://doi.org/10.1016/j.bjbas.2018.10.004 
Ramos Tercero, E.A., Domenicali, G., Bertucco, A., 2014. Autotrophic production of biodiesel from microalgae: An updated process and economic analysis. Energy 76, 807-815. https://doi.org/10.1016/j.energy.2014.08.077

Remias, D., Karsten, U., Lütz, C., Leya, T., 2010. Physiological and morphological processes in the Alpine snow alga Chloromonas nivalis (Chlorophyceae) during cyst formation. Protoplasma 243, 73-86. https://doi.org/10.1007/s00709-010-0123-y

Ras, M., Steyer, J.-P., Bernard, O., 2013. Temperature effect on microalgae: a crucial factor for outdoor production. Rev. Environ. Sci. Biotechnol. 12, 153-164. https://doi.org/10.1007/s11157-013-9310-6

Razzak, S.A., Hossain, M.M., Lucky, R.A., Bassi, A.S., de Lasa, H., 2013. Integrated CO2 capture, wastewater treatment and biofuel production by microalgae culturing-A review. Renew. Sustain. Energy Rev. 27, 622-653. https://doi.org/10.1016/j.rser.2013.05.063

Reyes, F.A., Sielfeld, C.S., del Valle, J.M., 2016. Effect of high-pressure compaction on supercritical $\mathrm{CO} 2$ extraction of astaxanthin from Haematococcus pluvialis. J. Food Eng. 189, 123-134. https://doi.org/10.1016/j.jfoodeng.2016.05.008

Rodrigues, M.A., da Silva Bon, E.P., 2011. Evaluation of Chlorella (Chlorophyta) as Source of Fermentable Sugars via Cell Wall Enzymatic Hydrolysis. Enzyme Res. 2011. https://doi.org/10.4061/2011/405603

Rodríguez-Meizoso, I., Jaime, L., Santoyo, S., Señoráns, F.J., Cifuentes, A., Ibáñez, E., 2010. Subcritical water extraction and characterization of bioactive compounds from Haematococcus pluvialis microalga. J. Pharm. Biomed. Anal., Natural Bioactive Compounds and Nutrigenomics 51, 456-463. https://doi.org/10.1016/j.jpba.2009.03.014

Rounsaville, J., Rice, R.G., 1996. Evolution of ozone for the bleaching of paper pulps. Ozone Sci. Eng. 18, 549-566. https://doi.org/10.1080/01919512.1997.10382863

Ruiz, H.A., Silva, D.P., Ruzene, D.S., Lima, L.F., Vicente, A.A., Teixeira, J.A., 2012. Bioethanol production from hydrothermal pretreated wheat straw by a flocculating Saccharomyces cerevisiae strain - Effect of process conditions. Fuel 95, 528-536. https://doi.org/10.1016/j.fuel.2011.10.060

Ruiz-Ruiz, F., Benavides, J., Rito-Palomares, M., 2013. Scaling-up of a B-phycoerythrin production and purification bioprocess involving aqueous two-phase systems: Practical experiences. Process Biochem. 48, 738-745. https://doi.org/10.1016/j.procbio.2013.02.010

Ryckebosch, E., Muylaert, K., Eeckhout, M., Ruyssen, T., Foubert, I., 2011. Influence of drying and storage on lipid and carotenoid stability of the microalga Phaeodactylum tricornutum. J. Agric. Food Chem. 59, 11063-11069. https://doi.org/10.1021/jf2025456

Safi, C., Camy, S., Frances, C., Varela, M.M., Badia, E.C., Pontalier, P.-Y., Vaca-Garcia, C., 2014. Extraction of lipids and pigments of Chlorella vulgaris by supercritical carbon dioxide: influence of bead milling on extraction performance. J. Appl. Phycol. 26, 1711-1718. https://doi.org/10.1007/s10811-013-0212-3

Safi, C., Cabas Rodriguez, L., Mulder, W.J., Engelen-Smit, N., Spekking, W., van den Broek, L.A.M., Olivieri, G., Sijtsma, L., 2017a. Energy consumption and water-soluble protein release by cell wall disruption of Nannochloropsis gaditana. Bioresour. Technol. 239, 204-210. https://doi.org/10.1016/j.biortech.2017.05.012

Safi, C., Olivieri, G., Campos, R.P., Engelen-Smit, N., Mulder, W.J., van den Broek, L.A.M., Sijtsma, L., 2017b. Biorefinery of microalgal soluble proteins by sequential processing and membrane filtration. Bioresour. Technol. 225, 151-158. https://doi.org/10.1016/j.biortech.2016.11.068 
Sahoo, N.K., Gupta, S.K., Rawat, I., Ansari, F.A., Singh, P., Naik, S.N., Bux, F., 2017. Sustainable dewatering and drying of self-flocculating microalgae and study of cake properties. J. Clean. Prod. 159, 248-256. https://doi.org/10.1016/j.jclepro.2017.05.015

Samarasinghe, N., Fernando, S., Lacey, R., Faulkner, W.B., 2012. Algal cell rupture using high pressure homogenization as a prelude to oil extraction. Renew. Energy 48, 300308. https://doi.org/10.1016/j.renene.2012.04.039

Shankar, M., Chhotaray, P.K., Agrawal, A., Gardas, R.L., Tamilarasan, K., Rajesh, M., 2017. Protic ionic liquid-assisted cell disruption and lipid extraction from fresh water Chlorella and Chlorococcum microalgae. Algal Res. 25, 228-236. https://doi.org/10.1016/j.algal.2017.05.009

Scherer, D., Krust, D., Frey, W., Mueller, G., Nick, P., Gusbeth, C., 2019. Pulsed electric field (PEF)-assisted protein recovery from Chlorella vulgaris is mediated by an enzymatic process after cell death. Algal Res. 41, 101536. https://doi.org/10.1016/j.algal.2019.101536

Seo, Y.H., Sung, M., Oh, Y.-K., Han, J.-I., 2016. Lipid extraction from microalgae cell using persulfate-based oxidation. Bioresour. Technol. 200, 1073-1075. https://doi.org/10.1016/j.biortech.2015.10.106

Seo, Y.H., Sung, M., Oh, Y.-K., Han, J.-I., 2015a. Lipid extraction from microalgae cell using UV-Fenton-like reaction. Bioresour. Technol. 192, 792-794. https://doi.org/10.1016/j.biortech.2015.04.108

Seo, Y.H., Sung, M., Oh, Y.-K., Han, J.-I., 2015b. Lipid extraction and esterification for microalgae-based biodiesel production using pyrite (FeS2). Bioresour. Technol. 191, 420-425. https://doi.org/10.1016/j.biortech.2015.02.083

Shannon, E., Abu-Ghannam, N., 2018. Enzymatic extraction of fucoxanthin from brown seaweeds. Int. J. Food Sci. Technol. 53, 2195-2204. https://doi.org/10.1111/ijfs.13808

Shelef, G., Sukenik, A., Green, M., 1984. Microalgae harvesting and processing: a literature review (No. SERI/STR-231-2396, 6204677). https://doi.org/10.2172/6204677

Shene, C., Monsalve, M.T., Vergara, D., Lienqueo, M.E., Rubilar, M., 2016. High pressure homogenization of Nannochloropsis oculata for the extraction of intracellular components: Effect of process conditions and culture age. Eur. J. Lipid Sci. Technol. 118, 631-639. https://doi.org/10.1002/ejlt.201500011

Sheng, J., Vannela, R., Rittmann, B.E., 2011. Evaluation of Cell-Disruption Effects of PulsedElectric-Field Treatment of Synechocystis PCC 6803. Environ. Sci. Technol. 45, 3795-3802. https://doi.org/10.1021/es103339x

Shi, W., Zhu, L., Chen, Q., Lu, J., Pan, G., Hu, L., Yi, Q., 2017. Synergy of flocculation and flotation for microalgae harvesting using aluminium electrolysis. Bioresour. Technol. 233, 127-133. https://doi.org/10.1016/j.biortech.2017.02.084

Shokrkar, H., Ebrahimi, S., Zamani, M., 2017. Bioethanol production from acidic and enzymatic hydrolysates of mixed microalgae culture. Fuel 200, 380-386. https://doi.org/10.1016/j.fuel.2017.03.090

Sierra, L.S., Dixon, C.K., Wilken, L.R., 2017. Enzymatic cell disruption of the microalgae Chlamydomonas reinhardtii for lipid and protein extraction. Algal Res. 25, 149-159. https://doi.org/10.1016/j.algal.2017.04.004

Simpson, R.J., 2010. Disruption of Cultured Cells by Nitrogen Cavitation. Cold Spring Harb. Protoc. 2010, pdb.prot5513. https://doi.org/10.1101/pdb.prot5513

Singh, D., Nedbal, L., Ebenhöh, O., 2018. Modelling phosphorus uptake in microalgae. Biochem. Soc. Trans. 46, 483-490. https://doi.org/10.1042/BST20170262

Şirin, S., Clavero, E., Salvadó, J., 2015. Efficient harvesting of Chaetoceros calcitrans for biodiesel production. Environ. Technol. 36, 1902-1912. https://doi.org/10.1080/09593330.2015.1015456 
Solé-Bundó, M., Carrère, H., Garfí, M., Ferrer, I., 2017. Enhancement of microalgae anaerobic digestion by thermo-alkaline pretreatment with lime $(\mathrm{CaO})$. Algal Res. 24, 199-206. https://doi.org/10.1016/j.algal.2017.03.025

Solovchenko, A.E., Ismagulova, T.T., Lukyanov, A.A., Vasilieva, S.G., Konyukhov, I.V., Pogosyan, S.I., Lobakova, E.S., Gorelova, O.A., 2019. Luxury phosphorus uptake in microalgae. J. Appl. Phycol. 31, 2755-2770. https://doi.org/10.1007/s10811-01901831-8

Spiden, E.M., Yap, B.H.J., Hill, D.R.A., Kentish, S.E., Scales, P.J., Martin, G.J.O., 2013. Quantitative evaluation of the ease of rupture of industrially promising microalgae by high pressure homogenization. Bioresour. Technol. 140, 165-171. https://doi.org/10.1016/j.biortech.2013.04.074

Steriti, A., Rossi, R., Concas, A., Cao, G., 2014. A novel cell disruption technique to enhance lipid extraction from microalgae. Bioresour. Technol. 164, 70-77. https://doi.org/10.1016/j.biortech.2014.04.056

Sumprasit, N., Wagle, N., Glanpracha, N., Annachhatre, A.P., 2017. Biodiesel and biogas recovery from Spirulina platensis. Int. Biodeterior. Biodegrad., Environmental Biotechnologies for Sustainable Development (EBSuD) 119, 196-204. https://doi.org/10.1016/j.ibiod.2016.11.006

T Lam, G.P., Van Der Kolk, J.A., Chordia, A., Vermuë, M.H., Olivieri, G., Eppink, M.H.M., Wijffels, R.H., 2017. Mild and Selective Protein Release of Cell Wall Deficient Microalgae with Pulsed Electric Field. ACS Sustain. Chem. Eng. 5, 6046-6053. https://doi.org/10.1021/acssuschemeng.7b00892

Taghavijeloudar, M., Park, J., Hashemi, S., Han, M., 2019. The effects of surfactants (sodium dodecyl sulfate, triton X-100 and cetyl trimethyl ammonium bromide) on the dewaterability of microalgae biomass using pressure filtration. Bioresour. Technol. 273, 565-572. https://doi.org/10.1016/j.biortech.2018.11.062

Taher, H., Al-Zuhair, S., Al-Marzouqi, A.H., Haik, Y., Farid, M., 2014. Effective extraction of microalgae lipids from wet biomass for biodiesel production. Biomass Bioenergy 66, 159-167. https://doi.org/10.1016/j.biombioe.2014.02.034

Teixeira, R.E., 2012. Energy-efficient extraction of fuel and chemical feedstocks from algae. Green Chem. 14, 419-427. https://doi.org/10.1039/C2GC16225C

Throndsen, J., 1997. Chapter 5 - The Planktonic Marine Flagellates, in: Tomas, C.R. (Ed.), Identifying Marine Phytoplankton. Academic Press, San Diego, pp. 591-729. https://doi.org/10.1016/B978-012693018-4/50007-0

Thu, N.T.H., Anh, H.T.L., Hoang, M.H., Kim, D.D., Hong, D.D., 2015. Study on biological characteristics of a newly isolated Vietnamese strain of microalga Isochrysis galbana Parke for utilizing as live aquaculture feed. Russ. J. Mar. Biol. 41, 203-211. https://doi.org/10.1134/S1063074015030074

Tilton, R.C., Murphy, J., Dixon, J.K., 1972. The flocculation of algae with synthetic polymeric flocculants. Water Res. 6, 155-164. https://doi.org/10.1016/00431354(72)90090-5

Tsutsumi, S., Yokomizo, M., Saito, Y., Matsushita, Y., Aoki, H., 2017. Mechanical cell disruption of microalgae for investigating the effects of degree of disruption on hydrocarbon extraction. Asia-Pac. J. Chem. Eng. 12, 454-467. https://doi.org/10.1002/apj.2088

Udom, I., Zaribaf, B.H., Halfhide, T., Gillie, B., Dalrymple, O., Zhang, Q., Ergas, S.J., 2013. Harvesting microalgae grown on wastewater. Bioresour. Technol. 139, 101-106. https://doi.org/10.1016/j.biortech.2013.04.002 
Uduman, N., Qi, Y., Danquah, M.K., Hoadley, A.F.A., 2010. Marine microalgae flocculation and focused beam reflectance measurement. Chem. Eng. J. 162, 935-940. https://doi.org/10.1016/j.cej.2010.06.046

Ugwu, C.U., Aoyagi, H., 2012. Microalgal Culture Systems: An Insight into their Designs, Operation and Applications. Biotechnology 11, 127-132. https://doi.org/10.3923/biotech.2012.127.132

Uquiche, E., Antilaf, I., Millao, S., 2016. Enhancement of pigment extraction from B. braunii pretreated using CO2 rapid depressurization. Braz. J. Microbiol. 47, 497-505. https://doi.org/10.1016/j.bjm.2016.01.020

Van Eykelenburg, C., 1977. On the morphology and ultrastructure of the cell wall of Spirulina platensis. Antonie Van Leeuwenhoek 43, 89-99. https://doi.org/10.1007/BF00395664

Van Haver, L., Nayar, S., 2017. Polyelectrolyte flocculants in harvesting microalgal biomass for food and feed applications. Algal Res. 24, 167-180. https://doi.org/10.1016/j.algal.2017.03.022

Vandamme, D., Beuckels, A., Markou, G., Foubert, I., Muylaert, K., 2015. Reversible Flocculation of Microalgae using Magnesium Hydroxide. BioEnergy Res. 8, 716-725. https://doi.org/10.1007/s12155-014-9554-1

Vandamme, D., Foubert, I., Fraeye, I., Meesschaert, B., Muylaert, K., 2012. Flocculation of Chlorella vulgaris induced by high $\mathrm{pH}$ : role of magnesium and calcium and practical implications. Bioresour. Technol. 105, 114-119. https://doi.org/10.1016/j.biortech.2011.11.105

Vandamme, D., Foubert, I., Muylaert, K., 2013. Flocculation as a low-cost method for harvesting microalgae for bulk biomass production. Trends Biotechnol. 31, 233-239. https://doi.org/10.1016/j.tibtech.2012.12.005

van Spronsen, J., Cardoso, M.A.T., Witkamp, G.-J., de Jong, W., Kroon, M.C., 2011. Separation and recovery of the constituents from lignocellulosic biomass by using ionic liquids and acetic acid as co-solvents for mild hydrolysis. Chem. Eng. Process. Process Intensif. 50, 196-199. https://doi.org/10.1016/j.cep.2010.12.010

Velasquez-Orta, S.B., Garcia-Estrada, R., Monje-Ramirez, I., Harvey, A., Orta Ledesma, M.T., 2014. Microalgae harvesting using ozoflotation: Effect on lipid and FAME recoveries. Biomass Bioenergy 70, 356-363. https://doi.org/10.1016/j.biombioe.2014.08.022

Vergnes, J.B., Gernigon, V., Guiraud, P., Formosa-Dague, C., 2019. Bicarbonate Concentration Induces Production of Exopolysaccharides by Arthrospira platensis That Mediate Bioflocculation and Enhance Flotation Harvesting Efficiency. ACS Sustain. Chem. Eng. 7, 13796-13804. https://doi.org/10.1021/acssuschemeng.9b01591

Wang, M., Yuan, W., 2016. Modeling bubble dynamics and radical kinetics in ultrasound induced microalgal cell disruption. Ultrason. Sonochem. 28, 7-14. https://doi.org/10.1016/j.ultsonch.2015.06.025

Wang, Meng, Yuan, W., 2015. Microalgal cell disruption in a high-power ultrasonic flow system. Bioresour. Technol. 193, 171-177. https://doi.org/10.1016/j.biortech.2015.06.040

Wang, M., Yuan, W., 2015. Microalgal Cell Disruption via Ultrasonic Nozzle Spraying. Appl. Biochem. Biotechnol. 175, 1111-1122. https://doi.org/10.1007/s12010-014-1350-z

Wang, S., Yerkebulan, M., Abomohra, A.E.-F., El-Khodary, S., Wang, Q., 2019. Microalgae harvest influences the energy recovery: A case study on chemical flocculation of Scenedesmus obliquus for biodiesel and crude bio-oil production. Bioresour. Technol. 286, 121371. https://doi.org/10.1016/j.biortech.2019.121371 
Wang, S., Huan J., Ke X., 2014. Effect of magnesium deficiency on photosynthetic physiology and triacylglyceride (TAG) accumulation of Chlorella vulgaris. Biomass and Bioenergy, 35, 1462-1467.

Wang, W., Lee, D.-J., Lai, J.-Y., 2015. Aggregate formation affects ultrasonic disruption of microalgal cells. Bioresour. Technol. 198, 907-912. https://doi.org/10.1016/j.biortech.2015.09.099

Weiss, N.D., Felby, C., Thygesen, L.G., 2019. Enzymatic hydrolysis is limited by biomasswater interactions at high-solids: improved performance through substrate modifications. Biotechnol. Biofuels 12, 3. https://doi.org/10.1186/s13068-018-1339-X

Wu, C., Xiao, Y., Lin, W., Li, J., Zhang, S., Zhu, J., Rong, J., 2017. Aqueous enzymatic process for cell wall degradation and lipid extraction from Nannochloropsis sp. Bioresour. Technol. 223, 312-316. https://doi.org/10.1016/j.biortech.2016.10.063

Wu, J., Liu, J., Lin, L., Zhang, C., Li, A., Zhu, Y., Zhang, Y., 2015. Evaluation of several flocculants for flocculating microalgae. Bioresour. Technol. 197, 495-501. https://doi.org/10.1016/j.biortech.2015.08.094

Wu, X., Zhou, C., Li, K., Zhang, W., Tao, Y., 2018. Probing the fouling process and mechanisms of submerged ceramic membrane ultrafiltration during algal harvesting under sub- and super-critical fluxes. Sep. Purif. Technol. 195, 199-207. https://doi.org/10.1016/j.seppur.2017.12.001

Xiao, C., Liao, Q., Fu, Q., Huang, Y., Chen, H., Zhang, H., Xia, A., Zhu, X., Reungsang, A., Liu, Z., 2019. A solar-driven continuous hydrothermal pretreatment system for biomethane production from microalgae biomass. Appl. Energy 236, 1011-1018. https://doi.org/10.1016/j.apenergy.2018.12.014

Xiaojian, D., Yun, H., Qiang, L., Qian, F., Ao, X., Chao, X., Xun, Z., Alissara, R., Zhidan, L., 2017. Medium-low temperature hydrothermal hydrolysis kinetic characteristics of concentrated wet microalgae biomass. Int. J. Agric. Biol. Eng. 10, 154-162. https://doi.org/10.25165/ijabe.v10i1.2699

Xie, Y., Ho, S.-H., Chen, C.-N.N., Chen, C.-Y., Jing, K., Ng, I.-S., Chen, J., Chang, J.-S., Lu, Y., 2016. Disruption of thermo-tolerant Desmodesmus sp. F51 in high pressure homogenization as a prelude to carotenoids extraction. Biochem. Eng. J. 109, $243-$ 251. https://doi.org/10.1016/j.bej.2016.01.003

Xu, L., Wang, F., Li, H.-Z., Hu, Z.-M., Guo, C., Liu, C.-Z., 2010. Development of an efficient electroflocculation technology integrated with dispersed-air flotation for harvesting microalgae. J. Chem. Technol. Biotechnol. 85, 1504-1507. https://doi.org/10.1002/jctb.2457

$\mathrm{Xu}$, Y., Purton, S., Baganz, F., 2013. Chitosan flocculation to aid the harvesting of the microalga Chlorella sorokiniana. Bioresource Technology 129, 296-301.

https://doi.org/10.1016/j.biortech.2012.11.068

Xue, Y., Li, Y., Zou, X., Xu, K., Wen, H., Zhang, B., Li, R., Shao, P., Fu, B., Gong, Y., 2019. Optimization of thermal preflocculation treatment for effective air flotation harvesting of microalgae [WWW Document]. https://doi.org/info:doi/10.1002/jctb.5941

Yap, B.H.J., Crawford, S.A., Dumsday, G.J., Scales, P.J., Martin, G.J.O., 2014. A mechanistic study of algal cell disruption and its effect on lipid recovery by solvent extraction. Algal Res. 5, 112-120. https://doi.org/10.1016/j.algal.2014.07.001

Yap, B.H.J., Dumsday, G.J., Scales, P.J., Martin, G.J.O., 2015. Energy evaluation of algal cell disruption by high pressure homogenisation. Bioresour. Technol., Advances in biofuels and chemicals from algae 184, 280-285. https://doi.org/10.1016/j.biortech.2014.11.049 
Ye, J., Sha, J., Liu, Q., Zhang, X., Hu, Q., Chen, Y., 2019. Influence of growth phase on the harvesting of Scenedesmus acuminatus using ultrafiltration. Sci. Total Environ. 660, 25-31. https://doi.org/10.1016/j.scitotenv.2019.01.020

Ye, Zhang., Tan, X.-H., Liu, Z.-W., Aadil, R.M., Tan, Y.-C., Inam-ur-Raheem, M., 2020 Mechanisms of breakdown of Haematococcus pluvialis cell wall by ionic liquids, hydrochloric acid and multi-enzyme treatment. Int. J. Food Sci. Technol. https://doi.org/10.1111/ijfs.14582

Yoo, G., Park, W.-K., Kim, C.W., Choi, Y.-E., Yang, J.-W., 2012. Direct lipid extraction from wet Chlamydomonas reinhardtii biomass using osmotic shock. Bioresour. Technol. 123, 717-722. https://doi.org/10.1016/j.biortech.2012.07.102

Yoo, G., Yoo, Y., Kwon, J.-H., Darpito, C., Mishra, S.K., Pak, K., Park, M.S., Im, S.G., Yang, J.-W., 2013. An effective, cost-efficient extraction method of biomass from wet microalgae with a functional polymeric membrane. Green Chem. 16, 312-319. https://doi.org/10.1039/C3GC41695J

Yu, X., Zhao, P., He, C., Li, J., Tang, X., Zhou, J., Huang, Z., 2012. Isolation of a novel strain of Monoraphidium sp. and characterization of its potential application as biodiesel feedstock. Bioresour. Technol. 121, 256-262. https://doi.org/10.1016/j.biortech.2012.07.002

Zakaria, S.M., Kamal, S.M.M., Harun, M.R., Omar, R., Siajam, S.I., 2017. Subcritical Water Technology for Extraction of Phenolic Compounds from Chlorella sp. Microalgae and Assessment on Its Antioxidant Activity. Molecules 22, 1105. https://doi.org/10.3390/molecules22071105

Zbinden, M.D.A., Sturm, B.S.M., Nord, R.D., Carey, W.J., Moore, D., Shinogle, H., StaggWilliams, S.M., 2013. Pulsed electric field (PEF) as an intensification pretreatment for greener solvent lipid extraction from microalgae. Biotechnol. Bioeng. 110, 16051615. https://doi.org/10.1002/bit.24829

Zhang, B., Feng, H., He, Z., Wang, S., Chen, H., 2018. Bio-oil production from hydrothermal liquefaction of ultrasonic pre-treated Spirulina platensis. Energy Convers. Manag. 159, 204-212. https://doi.org/10.1016/j.enconman.2017.12.100

Zhang, R., Grimi, N., Marchal, L., Lebovka, N., Vorobiev, E., 2019a. Effect of ultrasonication, high pressure homogenization and their combination on efficiency of extraction of bio-molecules from microalgae Parachlorella kessleri. Algal Res. 40, 101524. https://doi.org/10.1016/j.algal.2019.101524

Zhang, R., Grimi, N., Marchal, L., Vorobiev, E., 2019b. Application of high-voltage electrical discharges and high-pressure homogenization for recovery of intracellular compounds from microalgae Parachlorella kessleri. Bioprocess Biosyst. Eng. 42, 29-36. https://doi.org/10.1007/s00449-018-2010-4

Zhang, R., Marchal, L., Lebovka, N., Vorobiev, E., Grimi, N., 2020. Two-step procedure for selective recovery of bio-molecules from microalga Nannochloropsis oculata assisted by high voltage electrical discharges. Bioresour. Technol. 302, 122893. https://doi.org/10.1016/j.biortech.2020.122893

Zhang, R., Parniakov, O., Grimi, N., Lebovka, N., Marchal, L., Vorobiev, E., 2019c. Emerging techniques for cell disruption and extraction of valuable bio-molecules of microalgae Nannochloropsis sp. Bioprocess Biosyst. Eng. 42, 173-186. https://doi.org/10.1007/s00449-018-2038-5

Zhang, S., Gao, Y., Liu, Q., Ye, J., Hu, Q., Zhang, X., 2019. Harvesting of Isochrysis zhanjiangensis using ultrafiltration: Changes in the contribution ratios of cells and algogenic organic matter to membrane fouling under different cross-flow velocities. Algal Res. 41, 101567. https://doi.org/10.1016/j.algal.2019.101567 
Zhang, Y., Ward, V., Dennis, D., Plechkova, N.V., Armenta, R., Rehmann, L., 2018. Efficient Extraction of a Docosahexaenoic Acid (DHA)-Rich Lipid Fraction from Thraustochytrium sp. Using Ionic Liquids. Materials 11, 1986. https://doi.org/10.3390/ma11101986

Zhao, F., Chu, H., Tan, X., Zhang, Y., Yang, L., Zhou, X., Zhao, J., 2016. Comparison of axial vibration membrane and submerged aeration membrane in microalgae harvesting. Bioresour. Technol. 208, 178-183. https://doi.org/10.1016/j.biortech.2016.02.099

Zhao, F., Chu, H., Zhang, Y., Jiang, S., Yu, Z., Zhou, X., Zhao, J., 2017. Increasing the vibration frequency to mitigate reversible and irreversible membrane fouling using an axial vibration membrane in microalgae harvesting. J. Membr. Sci. 529, 215-223. https://doi.org/10.1016/j.memsci.2017.01.039

Zhao, F., Zhang, Y., Chu, H., Jiang, S., Yu, Z., Wang, M., Zhou, X., Zhao, J., 2018. A uniform shearing vibration membrane system reducing membrane fouling in algae harvesting. J. Clean. Prod. 196, 1026-1033. https://doi.org/10.1016/j.jclepro.2018.06.089

Zhu, Y., Dunford, N.T., Goad, C., 2014. Effect of Processing Parameters on Flocculation of $<$ Emphasis Type="Italic" $>$ Picochlorum oklahomensis $</$ Emphasis $>$. J. Am. Oil Chem. Soc. 91, 317-324. https://doi.org/10.1007/s11746-013-2371-4

Zuorro, A., Maffei, G., Lavecchia, R., 2016. Optimization of enzyme-assisted lipid extraction from Nannochloropsis microalgae. J. Taiwan Inst. Chem. Eng. 67, 106-114. https://doi.org/10.1016/j.jtice.2016.08.016

Table 1. Effects of medium composition on the chemical composition of various microalgae species. Table adapted from Juneja et al 2013. Information on magnesium from (Wang. et al. 2014, Polat et al. 2020). 


\begin{tabular}{|c|c|c|c|}
\hline Medium composition & Conditions & Microalgae specie & Biochemical modification \\
\hline \multirow{4}{*}{ Nitrogen } & \multirow{4}{*}{ Limitation } & Nannochloropsis oculata & Increase in lipid synthesis \\
\hline & & $\begin{array}{l}\text { Phaeodactylum } \\
\text { tricornutum }\end{array}$ & $\begin{array}{l}\text { Increase in lipid synthesis and } \\
\text { decrease in protein content }\end{array}$ \\
\hline & & Chlorella vulgaris & Increase in lipid synthesis \\
\hline & & Haematococcus pluvialis & $\begin{array}{l}\text { Increase in carotenoid } \\
\text { formation }\end{array}$ \\
\hline \multirow{3}{*}{ Phosphorus } & Limitation & $\begin{array}{l}\text { Chlamydomonas } \\
\text { reinhardtii }\end{array}$ & $\begin{array}{l}\text { Decrease in } \\
\text { phosphatidylglycerol }\end{array}$ \\
\hline & Limitation & Ankistrodesmus falcatus & $\begin{array}{l}\text { Decrease in chlorophyll and } \\
\text { protein; Increase in } \\
\text { carbohydrate and lipids }\end{array}$ \\
\hline & Starvation & Selenastrum minutum & $\begin{array}{l}\text { Reduced rate of respiration; } \\
\text { Decreased photosynthetic } \\
\mathrm{CO}_{2} \text { fixation }\end{array}$ \\
\hline \multirow{3}{*}{ Iron } & Limitation & Dunaliella tertiolecta & $\begin{array}{l}\text { Decrease in cellular } \\
\text { chlorophyll concentration }\end{array}$ \\
\hline & High concentration & Chlorella vulgaris & Increase in lipid content \\
\hline & High concentration & Haematococcus pluvialis & $\begin{array}{l}\text { Increase in carotenoid } \\
\text { formation }\end{array}$ \\
\hline \multirow{3}{*}{ Carbon } & $\begin{array}{l}\text { Increasing } \mathrm{CO}_{2} \\
\text { concentration at } 10 \% \\
\end{array}$ & $\begin{array}{l}\text { Chlamydomonas } \\
\text { reinhardtii }\end{array}$ & $\begin{array}{l}\text { Increase in amount of fatty } \\
\text { acid }\end{array}$ \\
\hline & $\begin{array}{l}\text { Increasing } \mathrm{CO}_{2} \\
\text { concentration at } 10 \% \\
\end{array}$ & Dunaliella salina & $\begin{array}{l}\text { Increase in amount of fatty } \\
\text { acid }\end{array}$ \\
\hline & $\begin{array}{l}\text { Elevated } \mathrm{CO}_{2} \\
\text { concentrations }\end{array}$ & Spirulina platensis & $\begin{array}{l}\text { Increase in carbohydrate } \\
\text { content; Decrease in proteins } \\
\text { and pigments }\end{array}$ \\
\hline \multirow{3}{*}{ Salinity } & $\begin{array}{l}\text { Increasing } \mathrm{NaCl} \\
\text { concentration }\end{array}$ & Dunaliella sp. & $\begin{array}{l}\text { Increase in saturated and } \\
\text { monounsaturated fatty acids }\end{array}$ \\
\hline & $\begin{array}{l}\text { Increasing } \mathrm{NaCl} \\
\text { concentration }\end{array}$ & Dunaliella tertiolecta & $\begin{array}{l}\text { Increase in intracellular lipids } \\
\text { and triglyceride } \\
\text { concentration }\end{array}$ \\
\hline & $\begin{array}{l}\text { Increasing } \mathrm{NaCl} \\
\text { concentration }\end{array}$ & Botryococcus braunii & $\begin{array}{l}\text { Increase in carbohydrate } \\
\text { content, and lipid content. } \\
\text { Decrease of protein content }\end{array}$ \\
\hline \multirow[t]{2}{*}{ Magnesium } & Magnesium deficiency & Chlorella Vulgaris & $\begin{array}{l}\text { Decrease chlorophyll and } \\
\text { protein. Increase in } \\
\text { triacylglyceride (TAG) } \\
\text { accumulation }\end{array}$ \\
\hline & Magnesium starvation & $\begin{array}{l}\text { Auxenochlorella } \\
\text { protothecoides }\end{array}$ & $\begin{array}{l}\text { Decrease the total } \\
\text { chlorophyll production. } \\
\text { Increase the lipid content }\end{array}$ \\
\hline
\end{tabular}


Table 2. Cell wall structures and high-value products of typical microalgae species

\begin{tabular}{|c|c|c|c|c|c|}
\hline $\begin{array}{l}\text { Robustness } \\
\text { of cell wall }\end{array}$ & Species & $\begin{array}{l}\text { Cell size } \\
(\mu \mathrm{m})\end{array}$ & Cell wall composition & Reference & Main product/price $^{\text {a }}$ \\
\hline High & Scenedesmus sp. & $5-7$ & $\begin{array}{l}\text { Trilaminar sheath (algaenan), Inner cell wall } \\
\text { (mannose, glucose), coenobial adhesive }\end{array}$ & (Baudelet et al., 2017). & Carbohydrates \\
\hline High & Haematococcus pluvialis & 20 & $\begin{array}{l}\text { Trilaminar sheath (algaenan), primary, } \\
\text { secondary and tertiary cell wall (mannose, } \\
\text { other sugars) }\end{array}$ & (Baudelet et al., 2017). & Astaxanthin / 1,450-5075 € kg-1 \\
\hline Medium & $\begin{array}{l}\text { Phaeodactylum } \\
\text { tricornutum }\end{array}$ & 25 & $\begin{array}{l}\text { Silica, sulfated } \alpha \text {-glucurunomannan, proteins, } \\
\text { polyamines }\end{array}$ & $\begin{array}{l}\text { (Johansen, 1991) (Le } \\
\text { Costaouëc et al., 2017) }\end{array}$ & Fucoxanthin/ \$ $200 \mathrm{~kg}^{-1}-4450 € \mathrm{~g}^{-1 \mathrm{~b}}$ \\
\hline Medium & Arthrospira platensis & 8 & $\begin{array}{l}\text { Peptidoglycan layer (Murein), two fibrillary } \\
\text { layers, sheath of acidic polysaccharides }\end{array}$ & $\begin{array}{l}\text { (Akao et al., 2019; } \\
\text { Kröger et al., 2018) }\end{array}$ & Phycocyanin $/ 360 € \mathrm{~kg}^{-1}$ \\
\hline Medium & Chloromonas nivalis & 15 & By-layered cell wall & (Remias et al., 2010) & Astaxanthin/ 1,450-5075€ kg-1 \\
\hline Medium & Dunaliella salina & $5-25$ & Double-layered rigid wall (hyaline, algaenan) & (Baudelet et al., 2017) & $\beta$-carotene/ $215-2150 € \mathrm{~kg}^{-1}$ \\
\hline Low & Isochrysis galbana & $5-6$ & Lack of cell wall, plasma membrane & (Thu et al., 2015) & $\omega 3 \omega 6 / 78-116 € \mathrm{~kg}^{-1}$ \\
\hline
\end{tabular}

${ }^{\mathrm{a}}$ as reviewed in (Cuellar-Bermudez et al., 2015), ${ }^{\mathrm{b}}$ from (Shannon and Abu-Ghannam, 2018) 
Table 3. Flocculation process parameters for typical polyelectrolytes. Table adapted from Van Haver and Nayar, 2017

\begin{tabular}{|c|c|c|c|c|c|c|c|}
\hline Flocculant & $\begin{array}{c}\text { Cell } \\
\text { concentration }\end{array}$ & $\begin{array}{l}\text { Dosage } \\
\left(\mathrm{mg} \mathrm{L}^{-1}\right)\end{array}$ & $\begin{array}{c}\text { Volume } \\
\text { (L) }\end{array}$ & $\begin{array}{l}\text { Time } \\
\text { (min) }\end{array}$ & Species & $\begin{array}{c}\text { Harvesting } \\
\text { efficiency } \\
(\%)\end{array}$ & Reference \\
\hline Chitosan & - & 20 & 0.5 & 240 & C. calcitrans & 98 & Harith et al. 2009 \\
\hline Magnafloc $®$ LT 25 & - & 0.1 & 0.5 & 240 & C. calcitrans & 83 & Harith et al. 2009 \\
\hline Chitosan+Sodium alginate & $1.24^{\mathrm{a}}$ & $30 \mathrm{ppm}+40 \mathrm{ppm}$ & 0.01 & 60 & S. obliquus & 90 & Matter et al., 2018 \\
\hline $\begin{array}{l}\text { Zetag } 7557, \\
\text { Polyacrylamide }\end{array}$ & $0.7^{\mathrm{b}}$ & 10 & 0.004 & 120 & Neochloris oleoabundans & 52 & Lam, 2017 \\
\hline $\begin{array}{l}\text { Synthofloc 5080H, } \\
\text { Polyacrylamide }\end{array}$ & $3.6^{\mathrm{b}}$ & 10 & 0.25 & 120 & P. tricornutum & 95 & Lam, 2017 \\
\hline Cationic starch & $0.77 \mathrm{~g} \mathrm{~L}^{-1}$ & 40 & - & 30 & C. protothecoides & 90 & Letelier-Gordo et al., 2014 \\
\hline Zetag 63, Polyacrylamide & $10^{6}$ cells $\mathrm{mL}^{-1}$ & 10 & 1 & 30 & Chlorella stimatophora & 93 & Van Haver and Nayar, 2017 \\
\hline $\begin{array}{l}\text { F04650, Polyacrylamide, } \\
\text { Medium charge }\end{array}$ & $0.7 \mathrm{~g} \mathrm{~L}^{-1}$ & 3 & 0.05 & 60 & N. salina & 73 & Van Haver and Nayar, 2017 \\
\hline $\begin{array}{l}\text { FO4800, Polyacrylamide, } \\
\text { High charge }\end{array}$ & $0.7 \mathrm{~g} \mathrm{~L}^{-1}$ & 3 & 0.05 & 60 & N. salina & 88 & Van Haver and Nayar, 2017 \\
\hline
\end{tabular}




\begin{tabular}{|c|c|c|c|c|c|c|c|}
\hline $\begin{array}{l}\text { FO4990, Polyacrylamide, } \\
\text { Very high charge }\end{array}$ & $0.7 \mathrm{~g} \mathrm{~L}^{-1}$ & 3 & 0.05 & 60 & N. salina & 94 & Van Haver and Nayar, 2017 \\
\hline $\begin{array}{l}\text { Emfloc KC750, Potato } \\
\text { starch }\end{array}$ & $10^{7}$ cells $\mathrm{mL}^{-1}$ & 70 & 0.1 & 30 & C. reinhardtii & 90 & Van Haver and Nayar, 2017 \\
\hline $\begin{array}{l}\text { POLYSEPAR®CFL25, } \\
\text { Tannin,quaternary } \\
\text { ammonia salt }\end{array}$ & $10^{7}$ cells mL $\mathrm{m}^{-1}$ & 30 & 0.1 & 30 & Chlorella sp. & 95 & Van Haver and Nayar, 2017 \\
\hline $\begin{array}{l}\text { Tanfloc SL, Tannin } \\
\text { Natural polymer }\end{array}$ & 0.26 & 5 & 3 & - & C. vulgaris & 100 & Van Haver and Nayar, 2017 \\
\hline
\end{tabular}

OD: Optical Density

${ }^{\mathrm{a}} \mathrm{OD} 680 \mathrm{~nm}$

${ }^{\mathrm{b}} \mathrm{OD}_{750 \mathrm{~nm}}$ 
Table 4. Process parameters and yields of typical microalgae harvesting processes

\begin{tabular}{|c|c|c|c|c|c|c|}
\hline Method & Species & Time & $\begin{array}{l}\text { Initial biomass } \\
\text { concentration }\end{array}$ & $\begin{array}{l}\text { Total } \\
\text { volume }\end{array}$ & $\begin{array}{l}\text { Harvesting } \\
\text { efficiency }\end{array}$ & Reference \\
\hline Gravitational settling & Monoraphidium sp. FXY-10 & $24 \mathrm{~h}$ & $0.218 \mathrm{~g} \mathrm{~L}^{-1}$ & - & $98 \%$ & Yu et al., 2012 \\
\hline Gravitational settling & A. platensis & - & $0.55 \mathrm{~g} \mathrm{~L}^{-1}$ & $1 \mathrm{~L}$ & $85 \%$ & Depraetere et al., 2015 \\
\hline Coagulation & N. salina & $2.5 \mathrm{~h}$ & $0.5 \mathrm{~g} \mathrm{~L}^{-1}$ & $0.113 \mathrm{~L}$ & $85 \%$ & Chatsungnoen and Chisti, 2016 \\
\hline Flocculation & C. reinhardtii & $0.25 \mathrm{~h}$ & $0.7 \mathrm{~g} \mathrm{~L}^{-1}$ & $0.1 \mathrm{~L}$ & $90 \%$ & Fan et al., 2017 \\
\hline Flocculation & C. calcitrans & $0.17 \mathrm{~h}$ & $0.095 \mathrm{~g} \mathrm{~L}^{-1}$ & $0.25 \mathrm{~L}$ & $89 \%$ & Şirin et al., 2015 \\
\hline Flocculation & C. vulgaris & $0.5 \mathrm{~h}$ & $0.5 \mathrm{~g} \mathrm{~L}^{-1}$ & $0.1 \mathrm{~L}$ & $90 \%$ & Vandamme et al., 2012 \\
\hline Flocculation & D. brasiliensis & $0.017 \mathrm{~h}$ & $0.5 \mathrm{~g} \mathrm{~L}^{-1}$ & $50 \mathrm{~L}$ & $99.2 \%$ & Ndikubwimana et al., 2016 \\
\hline Centrifugation & A. platensis & $0.17 \mathrm{~h}$ & $0.41 \mathrm{~g} \mathrm{~L}^{-1}$ & $0.005 \mathrm{~L}$ & $85 \%$ & Cuellar-Bermudez et al., 2019 \\
\hline Centrifugation & S. obliquus & $0.17 \mathrm{~h}$ & $0.746 \mathrm{~g} \mathrm{~L}^{-1}$ & $70 \mathrm{~L}$ & $99.3 \%$ & Wang et al., 2019 \\
\hline Dissolved air flotation & Mixed microalgae & - & $0.545 \mathrm{~g} \mathrm{~L}^{-1}$ & - & $91 \%$ & Niaghi et al., 2015 \\
\hline Flocculation-flotation & S. obliquus & $0.25 \mathrm{~h}$ & $0.73 \times 10^{6}$ cells $\mathrm{mL}^{1}$ & $1 \mathrm{~L}$ & $93.6 \%$ & Xue et al., 2019 \\
\hline Bioflocculation & A. plantensis & $0.25 \mathrm{~h}$ & $1.4 \mathrm{~g} \mathrm{~L}^{-1}$ & $0.6 \mathrm{~L}$ & $95 \%$ & Vergnes et al., 2019 \\
\hline Bioflocculation & Mixed microalgae & $0.083 \mathrm{~h}$ & $0.419 \mathrm{~g} \mathrm{~L}^{-1}$ & $0.95 \mathrm{~L}$ & $79.6 \%$ & Velasquez-Orta et al., 2014 \\
\hline
\end{tabular}


Table 5. Overview of major microalgae cell disruption methods

\begin{tabular}{|c|c|c|c|c|c|c|}
\hline Method & Mechanism & Advantages & Disadvantages & $\begin{array}{l}\text { Cell } \\
\text { concentration }\end{array}$ & $\begin{array}{l}\text { Selectivity } \\
\text { product } \\
\text { separation }\end{array}$ & $\begin{array}{l}\text { Energy } \\
\text { requirements }\end{array}$ \\
\hline Bead Milling & $\begin{array}{l}\text { Beads collision (cell } \\
\text { cleavage, fracture, abrasion) }\end{array}$ & $\begin{array}{l}\text { Effective cell disruption } \\
\text { High biomass } \\
\text { concentration }\end{array}$ & $\begin{array}{l}\text { Emulsification of } \\
\text { products } \\
\text { Requires cooling }\end{array}$ & High & Low & Low \\
\hline $\begin{array}{l}\text { High-pressure } \\
\text { homogenization }\end{array}$ & $\begin{array}{l}\text { shear stress induced } \\
\text { pressure drop }\end{array}$ & $\begin{array}{l}\text { Effective cell disruption } \\
\text { High biomass } \\
\text { concentration } \\
\text { Viscosity reduction }\end{array}$ & $\begin{array}{l}\text { Emulsification of } \\
\text { products may hamper } \\
\text { separation }\end{array}$ & High & Low & Low \\
\hline Ultrasonication & $\begin{array}{l}\text { Shear force from bubble } \\
\text { cavitation } \\
\text { Free radical } \\
\text { formation/oxidation }\end{array}$ & $\begin{array}{l}\text { Simple } \\
\text { Can be combined with } \\
\text { other processes }\end{array}$ & $\begin{array}{l}\text { Low disruption efficiency } \\
\text { Low-medium biomass } \\
\text { concentration } \\
\text { Requires cooling }\end{array}$ & Low-medium & Low & Low \\
\hline Pulsed Electric Field & $\begin{array}{l}\text { Electroporation of cell } \\
\text { wall/membrane }\end{array}$ & $\begin{array}{l}\text { Mild effect } \\
\text { High biomass } \\
\text { concentration }\end{array}$ & $\begin{array}{l}\text { Inefficient for small cell } \\
\text { size }\end{array}$ & High & Medium & Low \\
\hline
\end{tabular}




\begin{tabular}{|c|c|c|c|c|c|c|}
\hline $\begin{array}{l}\text { Hydrothermal/Steam } \\
\text { Explosion }\end{array}$ & $\begin{array}{l}\text { Explosion of cells from } \\
\text { pressure drop } \\
\text { Hydrolysis of cell wall } \\
\text { components }\end{array}$ & $\begin{array}{l}\text { Lack of reagents } \\
\text { Viscosity reduction due } \\
\text { to depolymerization of } \\
\text { macromolecules } \\
\text { Simple rector set-up }\end{array}$ & $\begin{array}{l}\text { Degradation of sensitive } \\
\text { products } \\
\text { Generation of } \\
\text { fermentation inhibitors } \\
\text { Hydrolysis of } \\
\text { carbohydrates \& protein } \\
\text { may be undesirable }\end{array}$ & Medium-High & Low & Medium \\
\hline Acid treatment & $\begin{array}{l}\text { Hydrolysis of cell wall } \\
\text { components }\end{array}$ & $\begin{array}{l}\text { Effective cell disruption } \\
\text { Simple rector set-up }\end{array}$ & $\begin{array}{l}\text { Neutralization of process } \\
\text { liquid } \\
\text { Degradation of sensitive } \\
\text { products } \\
\text { Generation of } \\
\text { fermentation inhibitors }\end{array}$ & Medium-High & Low & |Medium \\
\hline Alkaline treatment & $\begin{array}{l}\text { Hydrolysis of cell wall } \\
\text { components }\end{array}$ & $\begin{array}{l}\text { Effective cell disruption } \\
\text { Simple rector set-up }\end{array}$ & $\begin{array}{l}\text { Neutralization of process } \\
\text { liquid } \\
\text { Degradation of sensitive } \\
\text { products } \\
\text { Generation of } \\
\text { fermentation inhibitors }\end{array}$ & Medium-High & Low & Medium \\
\hline
\end{tabular}




\begin{tabular}{|l|l|l|l|l|l|l|}
\hline & & & Long treatment time & & \\
\hline Ozonolysis & $\begin{array}{l}\text { Oxidation of cell wall } \\
\text { components }\end{array}$ & $\begin{array}{l}\text { Optimal for biodiesel } \\
\text { production }\end{array}$ & $\begin{array}{l}\text { Oxidation of sensitive \& } \\
\text { high-value products }\end{array}$ & Low & Low \\
\hline Hydrogen peroxide & $\begin{array}{l}\text { Oxidation of cell wall } \\
\text { components }\end{array}$ & $\begin{array}{l}\text { Optimal for biodiesel } \\
\text { production }\end{array}$ & $\begin{array}{l}\text { Oxidation of sensitive \& } \\
\text { high-value products }\end{array}$ & Low & Low \\
Enzymatic & $\begin{array}{l}\text { Hydrolysis/ Oxidation of } \\
\text { cell wall components }\end{array}$ & $\begin{array}{l}\text { High specificity } \\
\text { Low temperature } \\
\text { No degradation }\end{array}$ & $\begin{array}{l}\text { Long process time } \\
\text { nigh }\end{array}$ & Ledium & Low \\
\hline
\end{tabular}


Table 6. Effect of different drying methods on extraction of biomolecules from S. obliquus. Table adapted from Ansari et al., 2018.

\begin{tabular}{|c|c|c|c|c|c|c|c|}
\hline $\begin{array}{l}\text { Drying } \\
\text { Method }\end{array}$ & Process conditions & $\begin{array}{c}\text { Lipid yield } \\
(\% \text { w/w })\end{array}$ & $\begin{array}{c}\text { Protein yield } \\
\qquad(\% \mathrm{w} / \mathrm{w})\end{array}$ & $\begin{array}{c}\text { Carbohydrate } \\
\text { yield } \\
(\% \mathrm{w} / \mathrm{w})\end{array}$ & $\begin{array}{l}\text { Energy } \\
\left(\mathrm{KWh} \mathrm{kg}^{-1}\right)\end{array}$ & Cost & Reference \\
\hline Untreated & - & - & 31.07 & 19.9 & - & - & $\begin{array}{c}\text { Ansari et al., } \\
2018\end{array}$ \\
\hline Sun-drying & $\begin{array}{l}\text { Natural sunlight (400- } \\
\left.1200 \mathrm{mmolm}^{-2} \mathrm{~s}^{-1}\right) \text {, } \\
18-27^{\circ} \mathrm{C}, 2-3 \text { days }\end{array}$ & 11.64 & 25.7 & 19.5 & 0.055 & $0.011 \$ \mathrm{~L}^{-1}$ & $\begin{array}{c}\text { Ansari et al., } \\
2018\end{array}$ \\
\hline Freeze-drying & $\begin{array}{c}\text { Deep freeze }-84^{\circ} \mathrm{C} \\
0.9 \mathrm{~kW} \text { for } 24 \mathrm{~h}\end{array}$ & 18.45 & 31 & 21.3 & 21.81 & $1.189 \$ \mathrm{~L}^{-1}$ & $\begin{array}{c}\text { Ansari et al., } \\
2018\end{array}$ \\
\hline Oven-drying & Air oven, $60^{\circ} \mathrm{C} 12 \mathrm{~h}$ & 13 & 30.98 & 18.8 & 6.33 & $0.343 \$ \mathrm{~L}^{-1}$ & $\begin{array}{c}\text { Ansari et al., } \\
2018\end{array}$ \\
\hline Spray dryer & - & - & - & - & 6.1 & $0.30 € \mathrm{~kg}^{-1}$ & $\begin{array}{c}\text { Fasaei et al. } \\
2018\end{array}$ \\
\hline Drum dryer & - & - & - & - & 5.1 & $0.25 € \mathrm{~kg}^{-1}$ & $\begin{array}{c}\text { Fasaei et al. } \\
2018\end{array}$ \\
\hline
\end{tabular}


Table 7. Effect of process severity factor during hydrothermal pretreatment on biomolecule extraction yields

\begin{tabular}{|c|c|c|c|c|c|c|c|}
\hline Species & $\begin{array}{l}\text { Pretreatment } \\
\text { method }\end{array}$ & $\begin{array}{c}\text { Reactor loading/ Biomass } \\
\text { Concentration }\end{array}$ & $\begin{array}{l}\text { Time } \\
\text { (min) }\end{array}$ & $\begin{array}{c}\text { Temperature } \\
\left({ }^{\circ} \mathrm{C}\right)\end{array}$ & $\log R_{o}$ & $\begin{array}{l}\text { Yield } \\
(\%)\end{array}$ & Reference \\
\hline \multicolumn{8}{|c|}{ Lipids } \\
\hline Chlorella sorokiniana & Steam explosion & $100 \mathrm{~g} / 20 \% \mathrm{w} / \mathrm{w}$ solids & 5 & 120 & 1.29 & $18.4^{\mathrm{a}}$ & Lorente et al., 2015 \\
\hline Nannochloropsis gaditana & Steam explosion & $250 \mathrm{~g} / 17 \% \mathrm{w} / \mathrm{w}$ solids & 5 & 120 & 1.29 & $3.6^{\mathrm{a}}$ & Nurra et al., 2014 \\
\hline Nannochloropsis gaditana & Steam explosion & $100 \mathrm{~g} / 20 \% \mathrm{w} / \mathrm{w}$ solids & 5 & 120 & 1.29 & $17.9^{\mathrm{a}}$ & Lorente et al., 2015 \\
\hline Nannochloropsis gaditana & Steam explosion & $100 \mathrm{~g} / 20 \% \mathrm{w} / \mathrm{w}$ solids & 5 & 150 & 2.17 & $18.2^{\mathrm{a}}$ & Lorente et al., 2015 \\
\hline Chlorella vulgaris & Hydrothermal & $30 \mathrm{~mL} / 50 \mathrm{~g} \mathrm{~L}^{-1}$ & 120 & 150 & 3.60 & $67.7^{\mathrm{c}}$ & Xiaojian et al., 2017 \\
\hline Nannochloropsis oceanica & Steam explosion & $200 \mathrm{~mL} / 10 \% \mathrm{w} / \mathrm{w}$ solids & 5 & 207.12 & 3.85 & $93.9^{\mathrm{b}}$ & Cheng et al., 2015 \\
\hline Nannochloropsis sp. & Hydrothermal & $\mathrm{na}^{\mathrm{e}} / 20 \mathrm{w} / \mathrm{w}$ solids & 60 & 180 & 4.13 & $84.0^{\mathrm{d}}$ & Qu et al., 2018 \\
\hline \multicolumn{8}{|c|}{ Carbohydrates } \\
\hline Nannochloropsis gaditana & Steam explosion & $100 \mathrm{~g} / 20 \% \mathrm{w} / \mathrm{w}$ solids & 5 & 120 & 1.29 & $43.7^{\mathrm{f}}$ & Lorente et al., 2015 \\
\hline Chlorella vulgaris & Hydrothermal & $\mathrm{na}^{\mathrm{e}} / 5 \mathrm{~g} \mathrm{tCOD} \mathrm{L}-1$ & 20 & 120 & 1.89 & $51.8^{\mathrm{f}}$ & Mendez et al., 2013 \\
\hline Nannochloropsis gaditana & Steam explosion & $100 \mathrm{~g} / 20 \% \mathrm{w} / \mathrm{w}$ solids & 5 & 150 & 2.17 & $44.4^{\mathrm{f}}$ & Lorente et al., 2015 \\
\hline Chlorella vulgaris & Hydrothermal & $\mathrm{na}^{\mathrm{e}} / 5 \mathrm{~g} \mathrm{tCOD} \mathrm{L} \mathrm{L}^{-1}$ & 40 & 120 & 2.19 & $58.2^{f}$ & Mendez et al., 2013 \\
\hline Chlorella pyrenoidosa & Hydrothermal & $\mathrm{na}^{\mathrm{e}} / 10 \% \mathrm{w} / \mathrm{w}$ solids & $10^{\mathrm{g}}$ & 160 & 2.77 & 46.9 & Fu et al., 2018 \\
\hline Chlorella pyrenoidosa & Hydrothermal & $\mathrm{na}^{\mathrm{e}} / 7 \%$ w/w solids & $15^{\mathrm{h}}$ & 155.2 & 2.80 & 80.5 & Xiao et al., 2019 \\
\hline
\end{tabular}




\begin{tabular}{|c|c|c|c|c|c|c|c|}
\hline Chlorella vulgaris & Hydrothermal & $30 \mathrm{~mL} / 50 \mathrm{~g} \mathrm{~L}^{-1}$ & 120 & 150 & 3.55 & 60.6 & Xiaojian et al., 2017 \\
\hline \multicolumn{8}{|c|}{ Protein } \\
\hline Chlorella vulgaris & Hydrothermal & $\mathrm{na}^{\mathrm{e}} / 5 \mathrm{~g} \mathrm{tCOD} \mathrm{L}$ & 20 & 120 & 1.89 & $20.2^{\mathrm{i}}$ & Mendez et al., 2013 \\
\hline Chlorella vulgaris & Hydrothermal & $\mathrm{na}^{\mathrm{e}} / 5 \mathrm{~g} \mathrm{tCOD} \mathrm{L}^{-1}$ & 40 & 120 & 2.19 & $26.4^{\mathrm{i}}$ & Mendez et al., 2013 \\
\hline Chlorella pyrenoidosa & Hydrothermal & $\mathrm{na}^{\mathrm{e}} / 10 \% \mathrm{w} / \mathrm{w}$ solids & 10 & 160 & 2.77 & $46.9^{\mathrm{j}}$ & Fu et al., 2018 \\
\hline Chlorella vulgaris & Hydrothermal & $30 \mathrm{~mL} / 50 \mathrm{~g} \mathrm{~L}^{-1}$ & 60 & 200 & 4.72 & $75.9^{j}$ & Xiaojian et al., 2017 \\
\hline
\end{tabular}

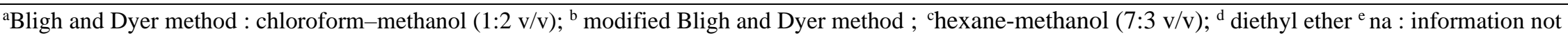

available:; ${ }^{\mathrm{f}}$ calculated as $\%$ of total monosaccharides measured in the pretreatment liquid; ${ }^{\mathrm{g}}$ retention time in a continuous system with a flow rate of $14 \mathrm{~L} \mathrm{~h}^{-1}{ }^{\mathrm{h}}{ }^{\mathrm{h}}$ retention time in a continuous system with a flow rate of $40 \mathrm{~L} \mathrm{~h}^{-1},{ }^{\mathrm{i}}$ calculated as $\%$ of total protein measured in the pretreatment liquid as total Kjeldahl nitrogen (TKN) $\mathrm{x} 5.95 ;{ }^{\mathrm{j}}$ calculated as $\%$ of total protein measured in the pretreatment liquid with the Lowry method 
Table 8. Effect of process severity factor during dilute acid pretreatment on biomolecule extraction yields

\begin{tabular}{|c|c|c|c|c|c|c|c|}
\hline & & Reactor loading/ & & & & & \\
\hline & & Biomass & Time & Temperature & & Yield & \\
\hline Species & Acid & Concentration & (min) & $\left({ }^{\circ} \mathrm{C}\right)$ & CSF & $(\%)$ & Reference \\
\hline \multicolumn{8}{|c|}{ Lipids } \\
\hline N. gaditana & $\mathrm{H}_{2} \mathrm{SO}_{4}, 5 \%$ w/w wet basis & $100 \mathrm{~g} / 20 \% \mathrm{w} / \mathrm{w}$ solids & 5 & 120 & 0.40 & $17.7^{\mathrm{a}}$ & Lorente et al., 2015 \\
\hline N. gaditana & $\mathrm{H}_{2} \mathrm{SO}_{4}, 10 \%$ w/w wet basis & $100 \mathrm{~g} / 20 \% \mathrm{w} / \mathrm{w}$ solids & 5 & 120 & 0.75 & $17.8^{\mathrm{a}}$ & Lorente et al., 2015 \\
\hline N. gaditana & $\mathrm{H}_{2} \mathrm{SO}_{4}, 5 \%$ w/w wet basis & $100 \mathrm{~g} / 20 \% \mathrm{w} / \mathrm{w}$ solids & 5 & 150 & 1.02 & $18.5^{\mathrm{a}}$ & Lorente et al., 2015 \\
\hline N. salina & $\mathrm{HNO}_{3} 0.57 \%, \mathrm{v} / \mathrm{v}$ & $\mathrm{na} / 20 \mathrm{~g} \mathrm{~L}^{-1}$ & 30 & 120 & 1.21 & $24.4^{\mathrm{b}}$ & Lee et al., 2014 \\
\hline N. gaditana & $\mathrm{H}_{2} \mathrm{SO}_{4}, 10 \%$ w/w wet basis & $100 \mathrm{~g} / 20 \% \mathrm{w} / \mathrm{w}$ solids & 5 & 150 & 1.40 & $18.5^{\mathrm{a}}$ & Lorente et al., 2015 \\
\hline N. gaditana & $\mathrm{H} 2 \mathrm{SO} 4,5 \%$ w/w wet basis & $100 \mathrm{~g} / 20 \% \mathrm{w} / \mathrm{w}$ solids & 5 & 150 & 1.87 & $79^{\mathrm{a}}$ & E. Lorente et al., 2017 \\
\hline N. salina & $\mathrm{HNO}_{3} 0.5 \%, \mathrm{v} / \mathrm{v}$ & $\mathrm{na} / 20 \mathrm{~g} \mathrm{~L}^{-1}$ & 60 & 120 & 1.94 & $88.4^{\mathrm{b}}$ & Lee and Han, 2015 \\
\hline \multicolumn{8}{|c|}{ Carbohydrates } \\
\hline mixed culture & $\mathrm{H}_{2} \mathrm{SO}_{4} 0.5 \mathrm{M}$ & na & 10 & 121 & 1.32 & $18^{\mathrm{c}}$ & Shokrkar et al., 2017 \\
\hline mixed culture & $\mathrm{H}_{2} \mathrm{SO}_{4} 0.5 \mathrm{M}$ & na & 20 & 121 & 1.62 & $44^{c}$ & Shokrkar et al., 2017 \\
\hline mixed culture & $\mathrm{H}_{2} \mathrm{SO}_{4} 1 \mathrm{M}$ & na & 20 & 121 & 1.92 & $58^{\mathrm{c}}$ & Shokrkar et al., 2017 \\
\hline mixed culture & $\mathrm{H}_{2} \mathrm{SO}_{4} 0.5 \mathrm{M}$ & na & 40 & 121 & 1.92 & $85^{\mathrm{c}}$ & Shokrkar et al., 2017 \\
\hline mixed culture & $\mathrm{H}_{2} \mathrm{SO}_{4} 1 \mathrm{M}$ & na & 40 & 121 & 2.22 & $92^{\mathrm{c}}$ & Shokrkar et al., 2017 \\
\hline
\end{tabular}


${ }^{\mathrm{a} B l i g h}$ and Dyer method : chloroform-methanol $(1: 2 \mathrm{v} / \mathrm{v}) ;{ }^{\mathrm{b}}$ hexane; ${ }^{c}$ total reducing sugar content of pretreatment liquid determined with dinitrosalicylic acid method 
Table 9. Extraction yield achieved by different cell disruption methods

\begin{tabular}{|c|c|c|c|c|c|c|c|}
\hline $\begin{array}{c}\text { Cell disruption } \\
\text { method }\end{array}$ & Species & $\begin{array}{l}\text { Time } \\
\text { (min) }\end{array}$ & $\begin{array}{c}\text { Process param } \\
\text { Temperature } \\
\left({ }^{\circ} \mathrm{C}\right)\end{array}$ & $\begin{array}{l}\text { Peters } \\
\text { Process specific }\end{array}$ & $\begin{array}{l}\text { Yield } \\
(\%)\end{array}$ & Extraction method & Reference \\
\hline \multicolumn{8}{|c|}{ Lipids } \\
\hline Bead milling & C. vulgaris & 60 & 33 & \begin{tabular}{|l}
$0.3-0.5 \mathrm{~mm}$ \\
$\mathrm{Y}_{2} \mathrm{O}_{3}$ stabilized \\
$\mathrm{ZrO}_{2}$ grinding \\
beads. \\
$1: 13$ solid:water \\
$\quad$ ratio $\left(\mathrm{w} \mathrm{v}^{-1}\right)$
\end{tabular} & 67 & $\begin{array}{c}\mathrm{SC}-\mathrm{CO}_{2} 600 \mathrm{bar}, 30 \mathrm{~g} \\
\mathrm{~min}^{-1} \mathrm{CO}_{2} \text { flow rate, } \\
5 \% \text { ethanol, } 60^{\circ} \mathrm{C}\end{array}$ & Safi et al., 2014 \\
\hline $\begin{array}{l}\text { High-pressure } \\
\text { homogenization }\end{array}$ & Chlorella $s p$ & - & - & $\begin{array}{c}\text { Single pass at } \\
1400 \text { bar }\end{array}$ & 100 & $\begin{array}{l}\text { modified Bligh and } \\
\text { Dyer, } 20 \text { min solvent } \\
\text { contact time }\end{array}$ & Yap et al., 2014 \\
\hline $\begin{array}{l}\text { Pulsed Electric } \\
\text { Field }\end{array}$ & A.protothecoides & - & - & 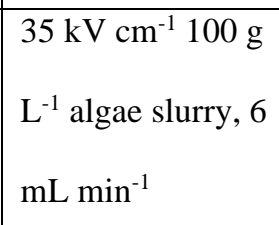 & $220 \mathrm{mg} \mathrm{g}^{-1}$ & $100 \%$ ethanol & Eing et al., 2013 \\
\hline Hydrothermal & $\begin{array}{l}\text { Nannochloropsis } \\
\text { sp. }\end{array}$ & 60 & 180 & $20 \mathrm{w} / \mathrm{w}$ solids & $84.0^{\mathrm{d}}$ & diethyl ether & Qu et al., 2018 \\
\hline
\end{tabular}




\begin{tabular}{|c|c|c|c|c|c|c|c|}
\hline Dilute acid & N. salina & 60 & 120 & $\begin{array}{l}\mathrm{HNO}_{3} 0.5 \% \mathrm{v} / \mathrm{v}, \\
20 \mathrm{~g} \mathrm{~L}^{-1} \text { algae } \\
\text { slurry }\end{array}$ & 88.4 & hexane & Lee and Han, 2015 \\
\hline Alkaline & $\begin{array}{l}\text { Nannochloropsis } \\
\text { sp. }\end{array}$ & 480 & 100 & $\begin{array}{l}300 \mathrm{~g} \mathrm{~L}^{-1} \text { algae } \\
\text { slurry, } \mathrm{pH} 10.5 \\
\text { (adjusted by } \\
2 \mathrm{mM} \mathrm{NaOH)}\end{array}$ & 83.5 & $30 \mathrm{~mL}$ chloroform & Wu et al., 2017 \\
\hline Oxidation & $\begin{array}{l}\text { Chlorella sp. } \\
\text { KR-1 }\end{array}$ & 60 & 90 & $\begin{array}{l}17 \mathrm{~g} \mathrm{~L}^{-1} \text { algae } \\
\text { slurry, } 2 \mathrm{mM} \\
\mathrm{K}_{2} \mathrm{~S}_{2} \mathrm{O}_{8}\end{array}$ & 95 & $\begin{array}{l}1 \mathrm{~h} \text { extraction with } 5 \mathrm{~mL} \\
\text { chloroform }\end{array}$ & Seo et al., 2016 \\
\hline Enzymatic & $\begin{array}{l}\text { Nannochloropsis } \\
\text { sp. }\end{array}$ & 210 & 53 & $\begin{array}{l}20 \mathrm{~g} \mathrm{~L}^{-1} \text { algae } \\
\text { slurry, } \mathrm{pH} 4.4, \\
\text { cellulase: } 13.8 \\
\mathrm{mg} \mathrm{g}^{-1} \text { biomass, } \\
\text { Endo- } \beta-1,4- \\
\text { mannanase: } 1.5 \\
\mathrm{mg} \mathrm{g}^{-1} \text { biomass }\end{array}$ & 90 & $\begin{array}{l}1 \mathrm{~h} \text { Extraction with } \\
\text { chloroform/methanol } \\
(2: 1, \mathrm{v} / \mathrm{v}) \text { and stirred at } \\
37^{\circ} \mathrm{C}\end{array}$ & Zuorro et al., 2016 \\
\hline
\end{tabular}




\begin{tabular}{|c|c|c|c|c|c|c|c|}
\hline Bead milling & T. suecica & 15 & 25 & $\begin{array}{l}\text { Yttrium } \\
\text { stabilized } \mathrm{ZrO}_{2} \\
0.3 \mathrm{~mm} \text { beads, } \\
\text { bead filling ratio } \\
65 \% \mathrm{v} / \mathrm{v},\end{array}$ & 99 & $\begin{array}{l}\text { Determined in the } \\
\text { supernatant by the } \\
\text { phenol - sulfuric acid } \\
\text { assay }\end{array}$ & Postma et al., 2017 \\
\hline $\begin{array}{l}\text { High-pressure } \\
\text { homogenization }\end{array}$ & C. vulgaris & - & $<25^{\circ} \mathrm{C}$ & $\begin{array}{l}5 \text { passes } 1500 \\
\text { bar, at } 155 \mathrm{~mL} \\
\min ^{-1}, 12 \mathrm{~g} \mathrm{~L}^{-1} \\
\text { biomass slurry }\end{array}$ & $\begin{array}{l}41.9 \% \\
(w / w)\end{array}$ & $\begin{array}{l}\text { Determined in the } \\
\text { supernatant by the } \\
\text { DuBois metod }\end{array}$ & Carullo et al., 2018 \\
\hline Hydrothermal & C. pyrenoidosa & $15^{\mathrm{h}}$ & 155 & $7 \%$ w/w solids & 80.5 & $\begin{array}{l}\text { Determined in the } \\
\text { supernatant bby the } \\
\text { phenol-sulfuric acid } \\
\text { method }\end{array}$ & Xiao et al., 2019 \\
\hline Dilute acid & mixed culture & 40 & 121 & $\mathrm{H}_{2} \mathrm{SO}_{4} 2 \mathrm{M}$ & $94^{\mathrm{c}}$ & $\begin{array}{l}\text { determined in the } \\
\text { pretreatment liquid with } \\
\text { dinitrosalicylic acid } \\
\text { method }\end{array}$ & Shokrkar et al., 2017 \\
\hline
\end{tabular}




\begin{tabular}{|c|c|c|c|c|c|c|c|}
\hline Alkaline & $\begin{array}{l}H . \\
\text { tetrachotoma } \\
\text { ME03 }\end{array}$ & 30 & 121 & $\begin{array}{l}10 \% \mathrm{w} / \mathrm{v} \\
\text { lyophilized } \\
\text { microalgae } \\
\text { slurry, } 2 \mathrm{M} \mathrm{NaOH}\end{array}$ & 80 & $\begin{array}{l}\text { determined in the } \\
\text { pretreatment liquid } \\
\text { anthrone method }\end{array}$ & Onay 2019 \\
\hline \multicolumn{8}{|c|}{ Protein } \\
\hline Bead milling & T. suecica & 6,67 & 25 & $\begin{array}{c}\text { Yttrium } \\
\text { stabilized } \mathrm{ZrO}_{2} \\
0.3 \mathrm{~mm} \text { beads, } \\
\text { bead filling ratio } \\
65 \% \mathrm{v} / \mathrm{v},\end{array}$ & 99 & $\begin{array}{l}\text { Determined in the } \\
\text { supernatant by the } \\
\text { Lowry assay }\end{array}$ & Postma et al., 2017 \\
\hline $\begin{array}{l}\text { High-pressure } \\
\text { homogenization }\end{array}$ & C. vulgaris & - & $<25^{\circ} \mathrm{C}$ & $\begin{array}{l}5 \text { passes } 1500 \\
\text { bar, at } 155 \mathrm{~mL} \\
\min ^{-1}, 12 \mathrm{~g} \mathrm{~L}^{-1} \\
\text { biomass slurry }\end{array}$ & $54.1 \%$ & $\begin{array}{l}\text { Determined in the } \\
\text { supernatant by the } \\
\text { Lowry assay }\end{array}$ & Carullo et al., 2018 \\
\hline Hydrothermal & C. vulgaris & 60 & 200 & $30 \mathrm{~mL} / 50 \mathrm{~g} \mathrm{~L}^{-1}$ & $75.9^{\mathrm{j}}$ & & Xiaojian et al., 2017 \\
\hline $\begin{array}{l}\text { Steam explosion } \\
\text { Dilute acid }\end{array}$ & C.sorokiniana & 5 & 150 & $\begin{array}{l}4 \text { kg microalgae } \\
\text { impregnated } \\
\text { with } \mathrm{H}_{2} \mathrm{SO}_{4} \text { at a } \\
\text { concentration of } \\
5 \% \mathrm{w} / \mathrm{w} \text { wet } \\
\text { sample basis }\end{array}$ & 55.7 & $\begin{array}{l}\text { determined in the } \\
\text { pretreatment liquid with } \\
\text { the bicinchoninic acid } \\
\text { protein assay }\end{array}$ & Lorente et al., 2018 \\
\hline
\end{tabular}




\begin{tabular}{|c|c|c|c|c|c|c|c|}
\hline Alkaline & C. vulgaris & 40 & 120 & $\begin{array}{l}25 \mathrm{~g} \mathrm{tCOD} \mathrm{L}^{-1} \\
\text { biomass slurry, } \\
\text { pH } 10 \text { (adjusted } \\
\text { by } 4 \mathrm{M} \mathrm{NaOH} \text { ) }\end{array}$ & 42 & $\begin{array}{l}\text { total Kjeldahl nitrogen } x \\
5.95\end{array}$ & Mendez et al., 2013 \\
\hline \multicolumn{8}{|c|}{ Pigments } \\
\hline Ball mill grinding & C. zofingiensis & 3.5 & - & $\begin{array}{l}10 \mathrm{~mm} \text { stainless } \\
\text { steel balls }\end{array}$ & 100 & $\begin{array}{l}\text { Acetone extraction of } \\
\text { lutein }\end{array}$ & Araya et al., 2014 \\
\hline $\begin{array}{l}\text { High-pressure } \\
\text { homogenization }\end{array}$ & $\begin{array}{l}\text { Desmodesmus } \\
\text { sp. F51 }\end{array}$ & - & - & $\begin{array}{l}2413 \text { bar, } 4 \\
\text { passes at } 40 \mathrm{~mL} \\
\min ^{-1}\end{array}$ & $\begin{array}{l}7.9 \mathrm{mg} \mathrm{g}^{-1} \\
\text { biomass }\end{array}$ & $\begin{array}{l}\text { carotenoids extracted by ethyl } \\
\text { ether }\end{array}$ & Xie et al., 2016 \\
\hline $\begin{array}{l}\text { Pulsed Electric } \\
\text { Field }\end{array}$ & H. pluvialis & - & & $\begin{array}{l}1 \mathrm{kV} \cdot \mathrm{cm}^{-1}, 10 \\
\text { pulses, } 50 \mathrm{~ms},\end{array}$ & 96 & $\begin{array}{l}\text { 6h post treatment } \\
\text { incubation followed by } \\
\text { extraction of astaxanthin } \\
\text { with } 99.5 \% \mathrm{v} / \mathrm{v} \\
\text { methanol }\end{array}$ & Martínez et al., 2019 \\
\hline Hydrothermal & H. pluvialis & 10 & 200 & $\begin{array}{l}\text { high temperature } \\
\text { and high pressure } \\
\text { microfluidic } \\
\text { platform }\end{array}$ & 100 & $\begin{array}{l}20 \text { min acetone } \\
\text { extraction of astaxanthin }\end{array}$ & Cheng et al., 2017 \\
\hline
\end{tabular}




\begin{tabular}{|l|l|l|l|l|l|l|l|}
\hline Dilute acid & H. pluvialis & 60 & 70 & $\begin{array}{l}4 \mathrm{M} \mathrm{HCl}, 10 \mathrm{~g}^{-1} \\
\text { algae slurry }\end{array}$ & 80 & $\begin{array}{l}60 \text { min acetone } \\
\text { extraction of astaxanthin }\end{array}$ & Liu et al., 2018 \\
\hline Alkaline & S. almeriensis & 80 & 20 & $\begin{array}{l}100 \mathrm{~g} \mathrm{~L}^{-1} \text { algae } \\
\text { slurry, } 4 \mathrm{w} / \mathrm{v} \% \\
\text { KOH }\end{array}$ & 99 & $\begin{array}{l}5 \text { min hexane extraction of } \\
\text { lutein }\end{array}$ & Cerón et al., 2008 \\
\hline
\end{tabular}


Table 10. Disruption and lipid extraction from C. vulgaris cells by various imidazolium based ionic liquids. Table adapted from (Orr et al., 2016).

\begin{tabular}{|c|c|c|c|c|c|c|}
\hline Species & Ionic liquid & $\begin{array}{l}\text { Algae/ionic } \\
\text { liquid ration }\end{array}$ & $\begin{array}{l}\text { Time } \\
\text { (min) }\end{array}$ & $\begin{array}{c}\text { Temperature } \\
\left({ }^{\circ} \mathrm{C}\right)\end{array}$ & Cell disruption $^{\mathrm{a}}$ & $\begin{array}{c}\text { Lipid yield } \\
\text { (\% total lipids) }\end{array}$ \\
\hline C. vulgaris & 1-ethyl-3-methylimidazolium chloride & $1: 20$ & 30 & 140 & Complete lysis & 96 \\
\hline C. vulgaris & 1-butyl-3-methylimidazolium chloride & $1: 20$ & 30 & 140 & Complete lysis & 88 \\
\hline C. vulgaris & 1-(2-hydroxylethyl)-3-methylimidazolium chloride & $1: 20$ & 30 & 140 & Complete lysis & 98 \\
\hline C. vulgaris & 1-allyl-3-methylimidazolium chloride & $1: 20$ & 30 & 140 & Complete lysis & 45 \\
\hline
\end{tabular}

${ }^{a}$ microscopic observation 
Table 11. Energy and cost requirements of typical microalgae harvesting methods. Table adapted from Fasaei et al., 2018

\begin{tabular}{|c|c|c|c|c|c|c|}
\hline $\begin{array}{l}\text { Harvesting } \\
\text { method }\end{array}$ & $\begin{array}{r}\text { Size or } \\
\text { processing } \\
\text { capacity }\end{array}$ & Costs & $\begin{array}{c}\text { Concentration of } \\
\text { biomass } \\
\left(\mathrm{kg} \mathrm{m}^{-3}\right)\end{array}$ & $\begin{array}{c}\text { Energy } \\
\text { requirement } \\
\left(\mathrm{kWh} \mathrm{m}^{-3}\right)\end{array}$ & $\begin{array}{c}\text { Biomass recovery } \\
(\%)\end{array}$ & $\begin{array}{c}\text { Output solid } \\
\text { concentration } \\
(\%)\end{array}$ \\
\hline Centrifuge & $80 \mathrm{~m}^{3} \cdot \mathrm{h}^{-1}$ & $250,000 €$ & 200 & $0.70-1.30$ & $95-99$ & $10-20$ \\
\hline Microfiltration & - & $300 € \mathrm{~m}^{-2}$ & 50 & - & - & - \\
\hline Flocculation & $100 \mathrm{~m}^{3}$ & 125,000 & - & - & - & - \\
\hline Spiral plate & $4 \mathrm{~m}^{3} \mathrm{~h}^{-1}$ & 229,000 & 200 & $0.95-2.00$ & 95-99 & $20-22$ \\
\hline $\begin{array}{l}\text { Dissolved air } \\
\text { flotation }\end{array}$ & $3.8 \mathrm{~L}$ & - & 0.545 & 0.0025 & 91 & - \\
\hline $\begin{array}{l}\text { Membrane } \\
\text { filtration }\end{array}$ & - & - & - & $0.80-2.51$ & 99 & $1.5-10$ \\
\hline Electroflocculation & $1.5 \mathrm{~L}$ & - & $0.3-0.6$ & $0.15-1$ & $80-95$ & - \\
\hline $\begin{array}{l}\text { Flocculation }+ \\
\text { Centrifuge }\end{array}$ & - & $0.98 € \mathrm{Kg}^{-1}$ & - & $0.06 \mathrm{kWh} \cdot \mathrm{kg}^{-1}$ & - & - \\
\hline $\begin{array}{l}\text { Flocculation + } \\
\text { Membrane filter }\end{array}$ & - & $0.97 € \mathrm{Kg}^{-1}$ & - & $0.05 \mathrm{kWh} \cdot \mathrm{kg}^{-1}$ & - & - \\
\hline
\end{tabular}




\begin{tabular}{|l|l|l|l|l|l|l|}
\hline Membrane filter + \\
Centrifuge
\end{tabular}


Table 12. Energy and cost requirements of cell disruption methods

\begin{tabular}{|c|c|c|c|c|c|}
\hline Disruption method & Species & $\begin{array}{c}\text { Biomass } \\
\text { concentration }\end{array}$ & $\begin{array}{c}\text { Energy } \\
\left(\mathrm{KWh} \mathrm{kg}^{-1}\right)\end{array}$ & Cost & Reference \\
\hline $\mathrm{HPH}$ & N. gatidana & $100 \mathrm{~g} \mathrm{~L}^{-1}$ & 0.32 & $0.15-0.25^{\mathrm{a}}$ & Safi et al. 2017 \\
\hline Bead milling & N. gatidana & $100 \mathrm{~g} \mathrm{~L}^{-1}$ & 0.43 & $0.4-1^{\mathrm{a}}$ & Safi et al. 2017 \\
\hline PEF & N. gatidana & $100 \mathrm{~g} \mathrm{~L}^{-1}$ & 10.42 & $2-20^{a}$ & Safi et al. 2017 \\
\hline Enzymatic & N. gatidana & $100 \mathrm{~g} \mathrm{~L}^{-1}$ & 0.34 & - & Safi et al. 2017 \\
\hline Ultrasound & S. obliquus & - & 1.5 & $0.26^{\mathrm{b}}$ & Ansari et al., 2018 \\
\hline Autoclave & S. obliquus & - & 1.58 & $0.26^{\mathrm{b}}$ & Ansari et al., 2018 \\
\hline Steam explosion & N. oceanica & $10 \% \mathrm{w} / \mathrm{w}$ & 2.26 & - & Cheng et al., 2015 \\
\hline Osmotic shock & S. obliquus & - & 1.72 & $0.31^{\mathrm{b}}$ & Ansari et al., 2018 \\
\hline
\end{tabular}


Figure captions

Figure 1. Overview of microalgae biorefinery

Figure 2. Cell wall structure of a: A Chlamydomonas biflagellate cell, B Desmodesmus four-celled coenobium, C mature Haematococcus lacustris cystm from (Baudelet et al., 2017), D Phaeodactylum tricornutum from (Gügi et al., 2015), E Arthrospira platensis (Van Eykelenburg, 1977) F Tisochrysis lutea (Orlova et al., 2019).

Figure 3. Typical mechanisms of microalgae flocculation (a) coagulation with bivalent cations (b) neutralization and bridging effect of cationic polymers (c) autoflocculation induced by excreted algogenic organic matter (d) detailed mechanism of flocculation with cationic polymers including "charge shielding" hypothesis for negative effect of high cationic polymer dosages (adapted from Lam, 2017)

Figure 4. Types of forces acting acting on microalgae cellss during bead milling. The diagram is not to scale and servesd for illustration purposes only.

Figure 5. Mechanism of cell disruption during High Pressure Homogenization. The cell sizedigram is not shown to scale. Pressure drop is the main effect of the process causingcause of the cell disruption.

Figure 6. Mechanism of cell disruption by ultrasound treatment

Figure 7. Pore formation in the cell membrane and subsequent release of intracellular molecules as a result of PEF treatment of microalgae cells 


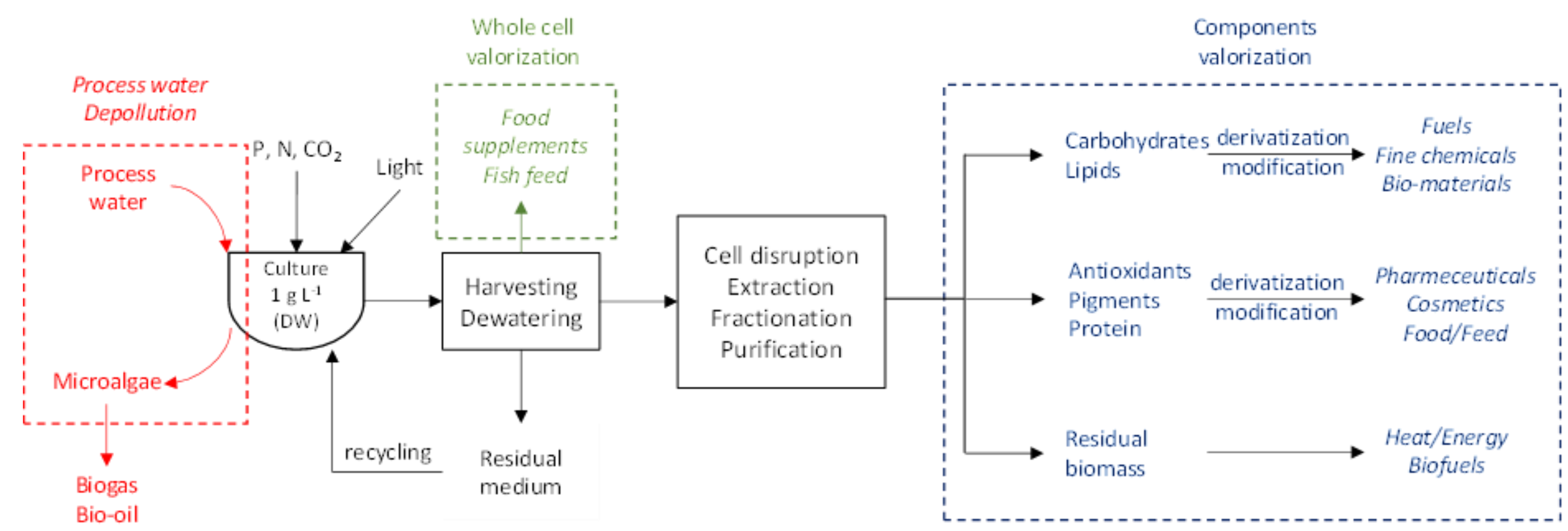

Figure 1 


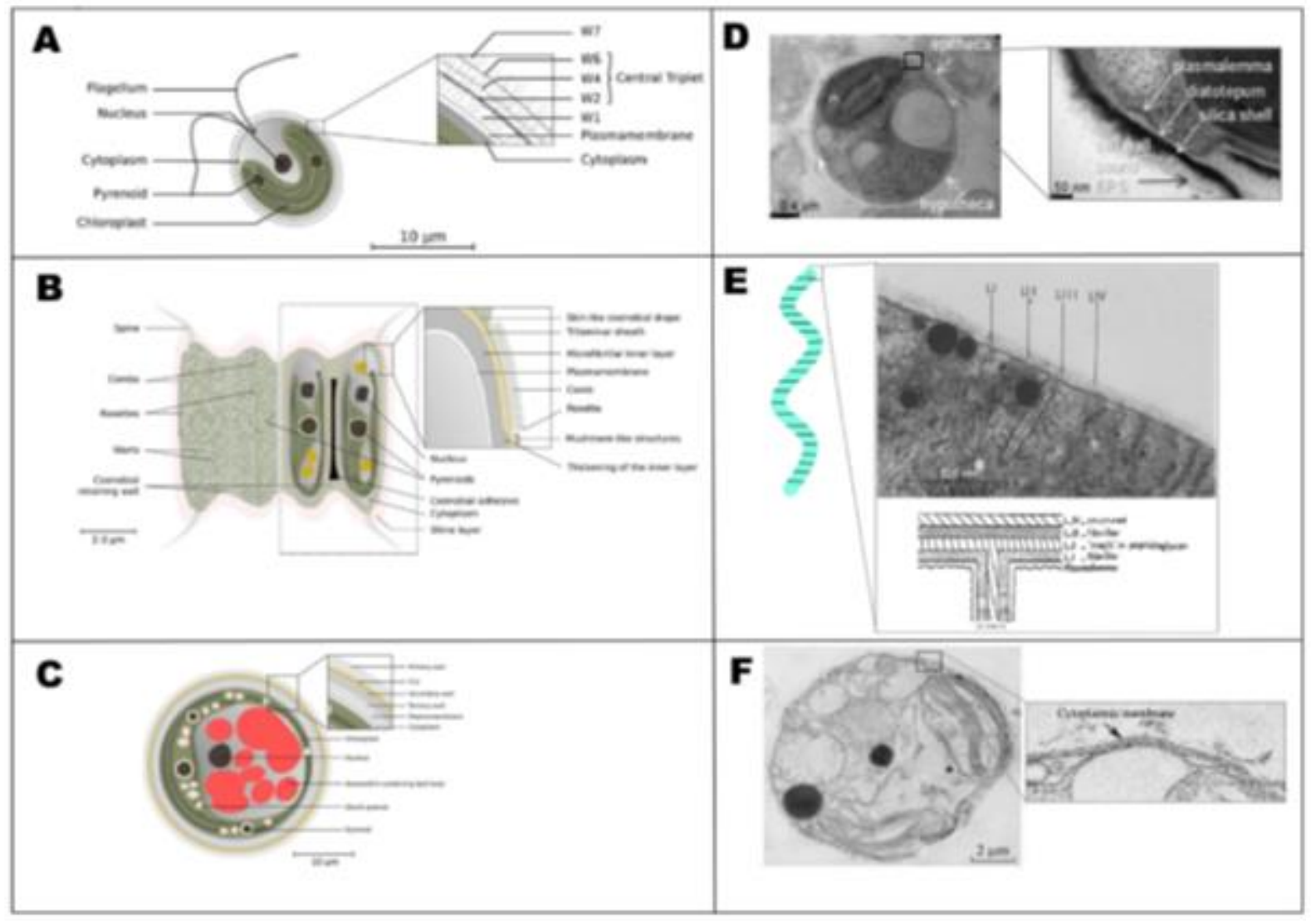

Figure 2 
(a)

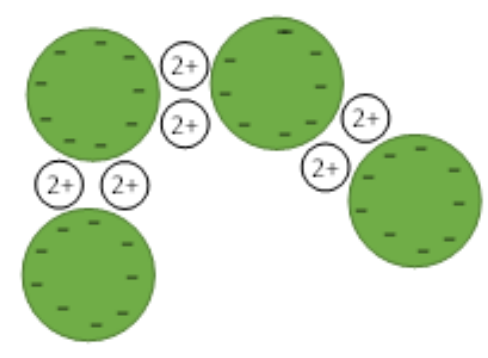

(d)

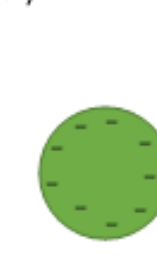

Stabilized cell (b)

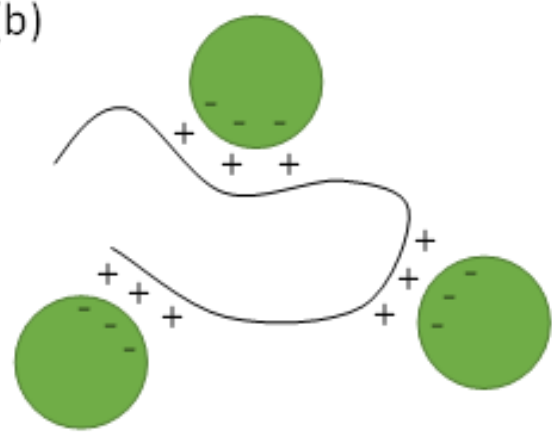

(c)

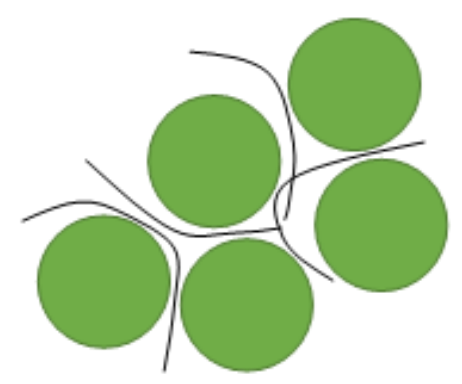

Flocculation with other cells

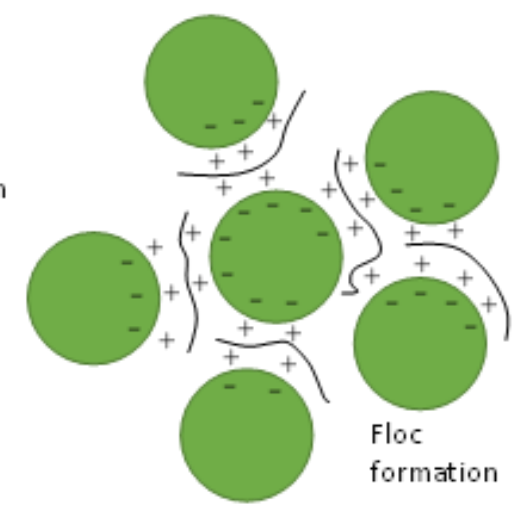

Adsorption

Desorption
Destabilized cell
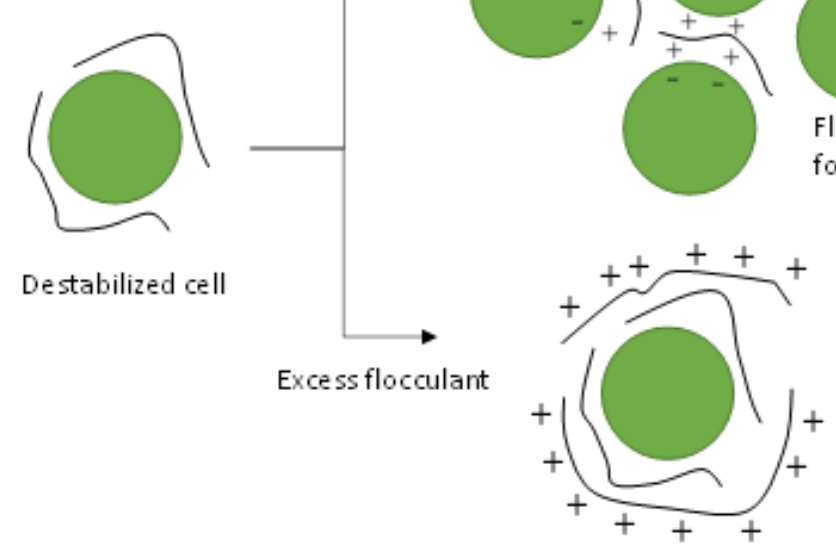

Charge reversion and cell stabilization

Figure 3 

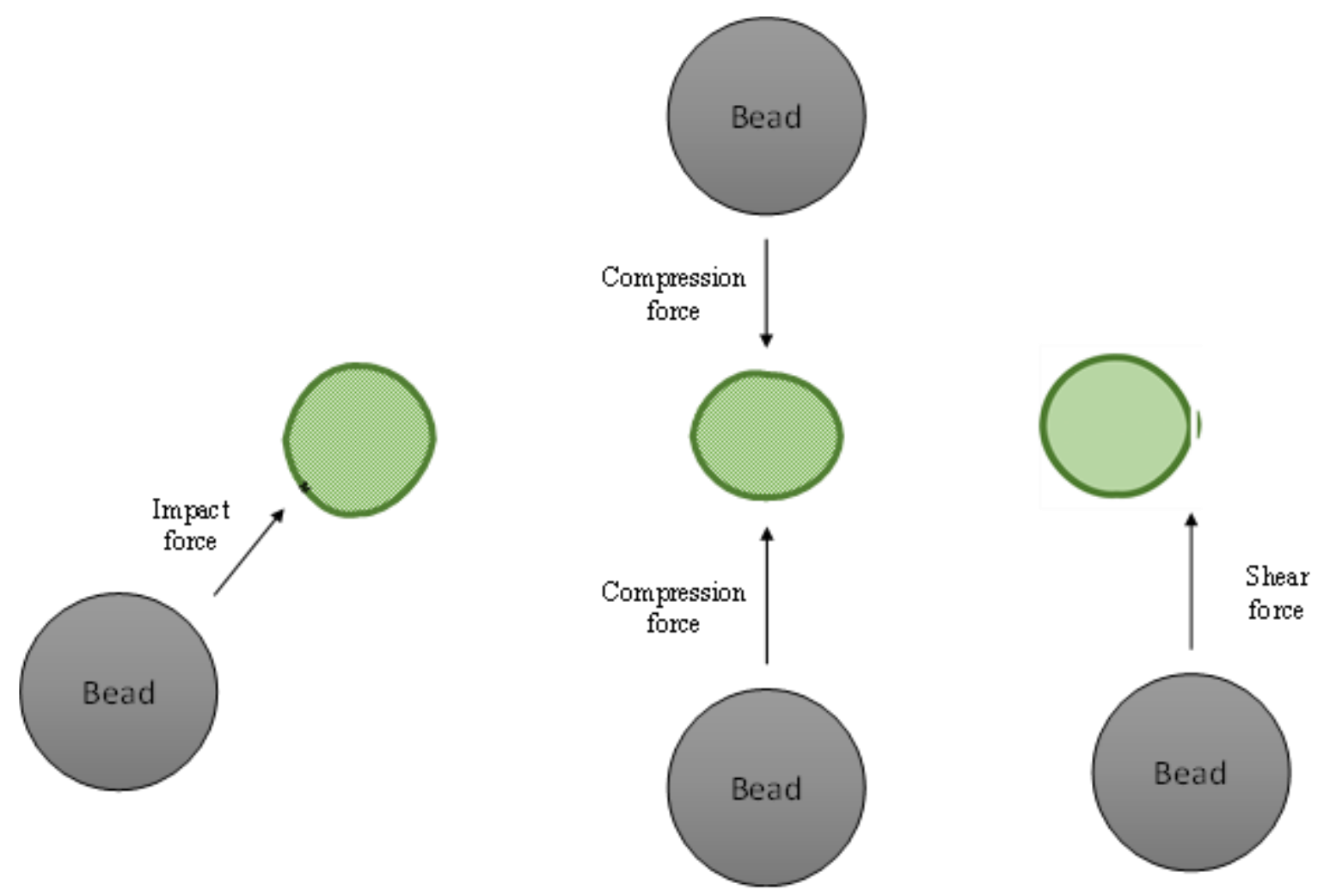

Figure 4 


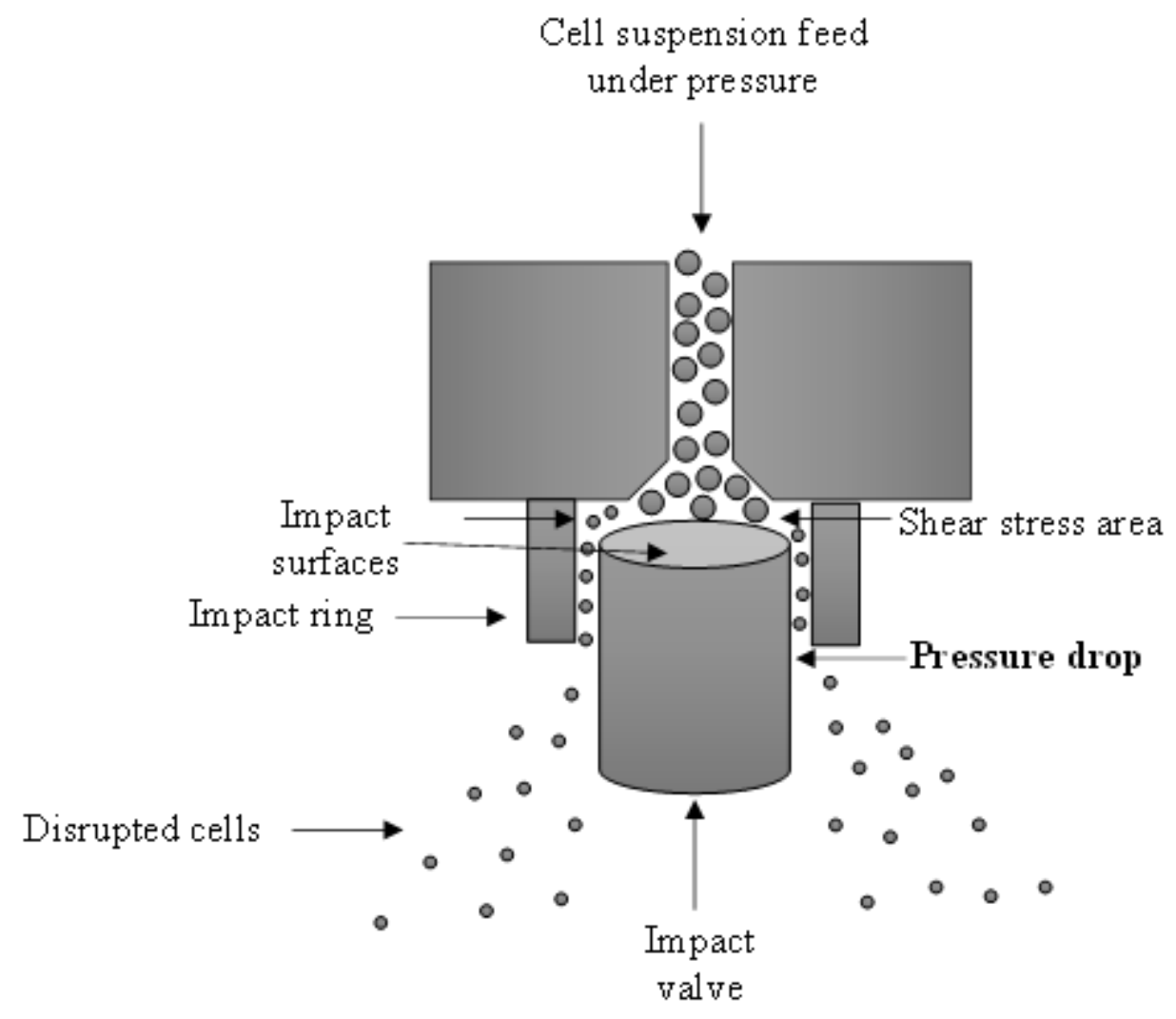

Figure 5 


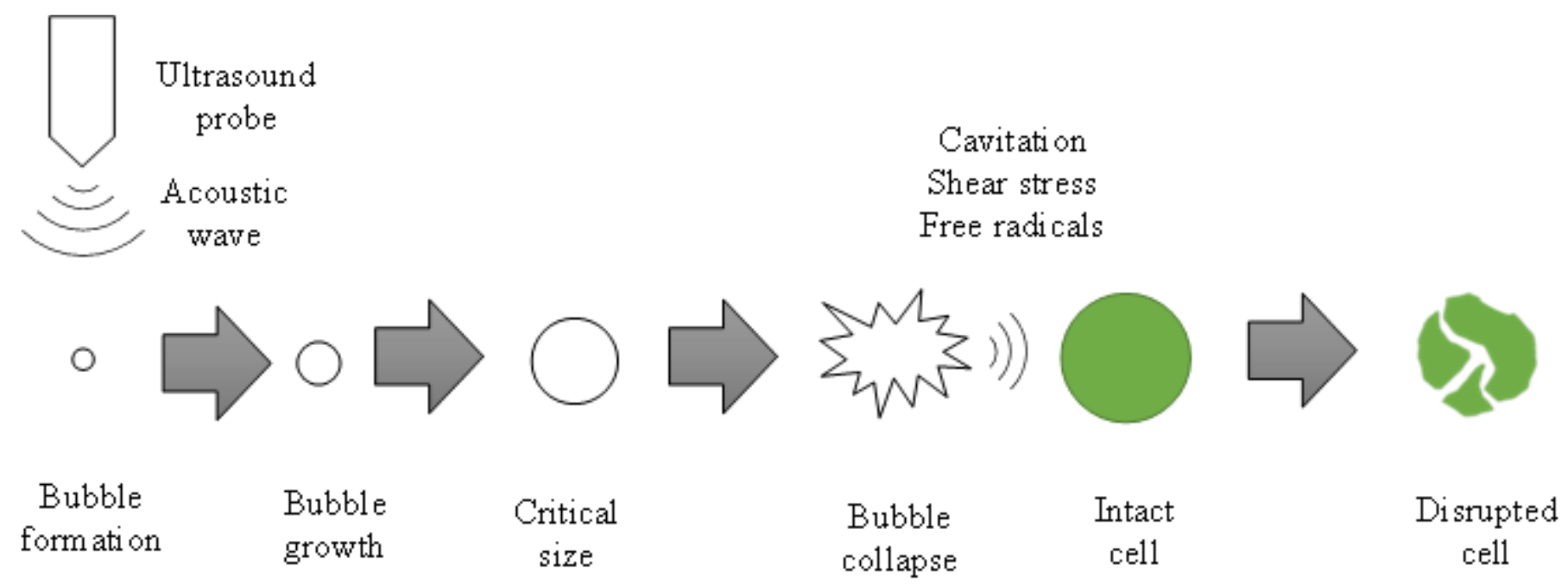

\section{Figure 6}




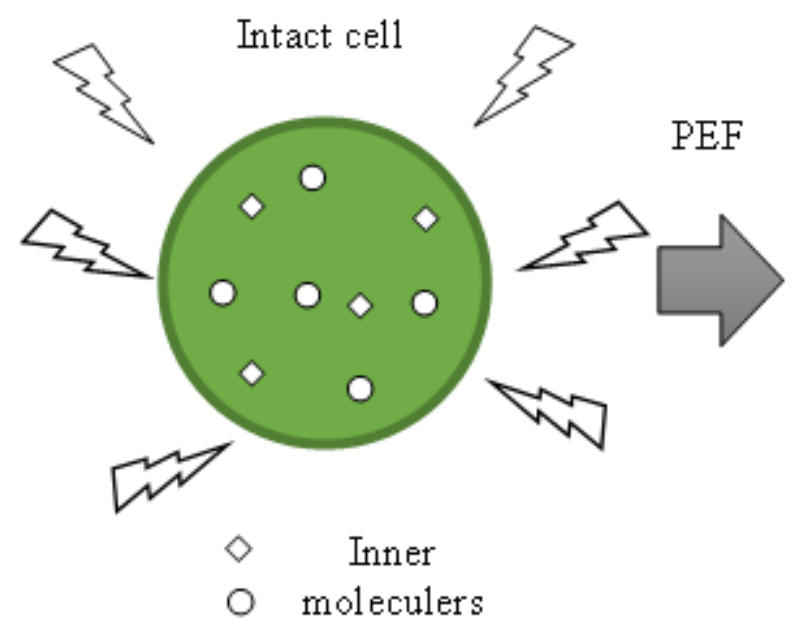

Electroporated cell

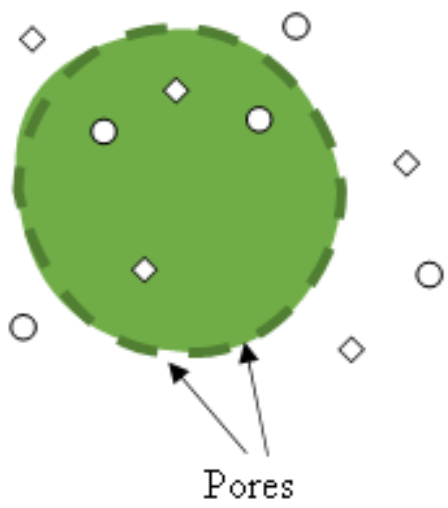

Figure 7 